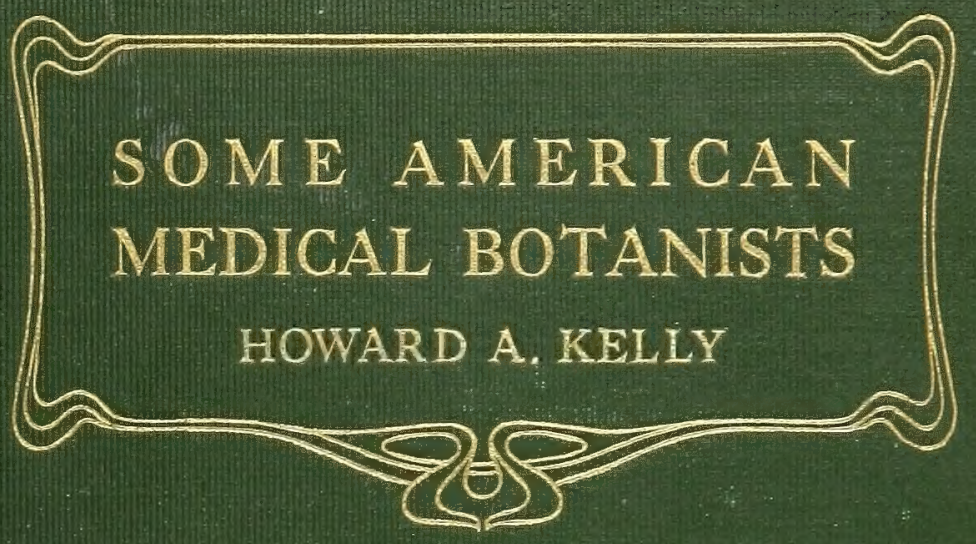



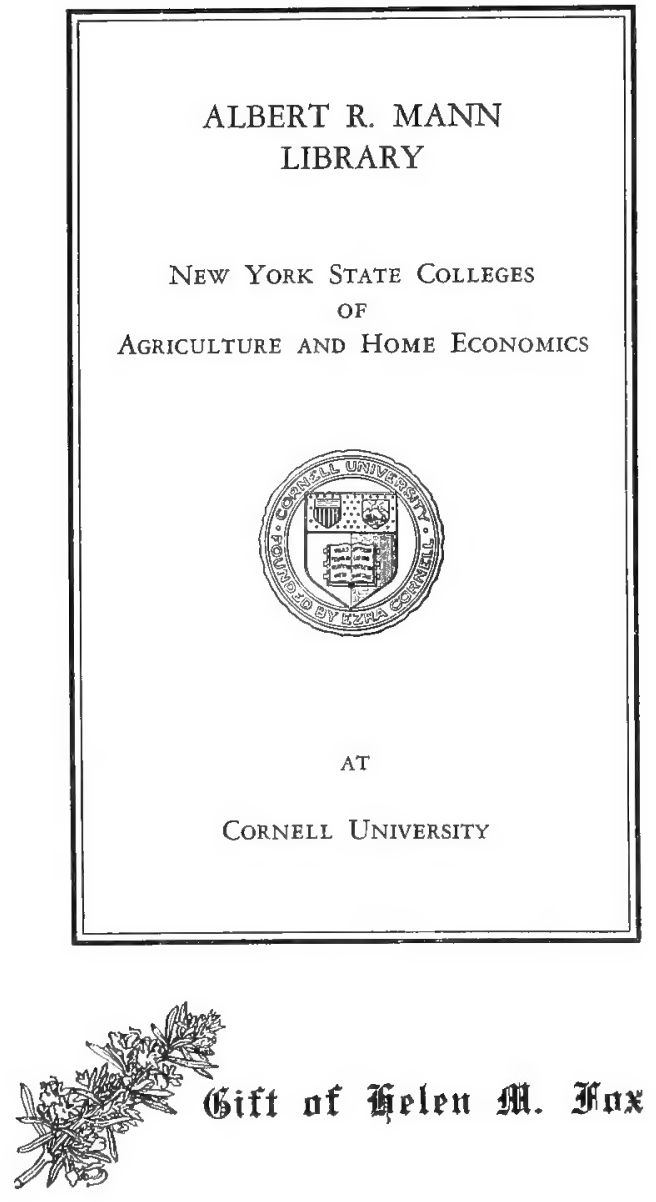


\section{Date Due}

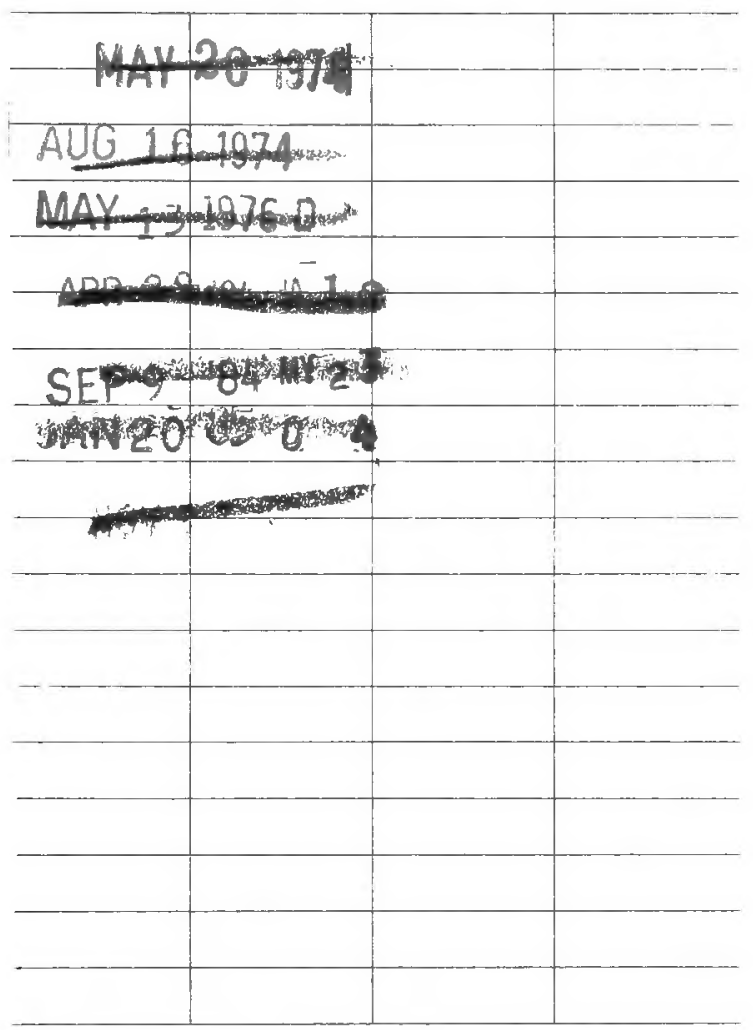

Library Bureau Cat. No. 1137

\section{QK 26.K29 Cornell University Library}

\section{Some American medical botanists commemor}

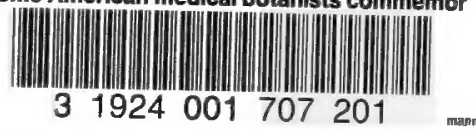




\section{Cornell University Library}

The original of this book is in the Cornell University Library.

There are no known copyright restrictions in the United States on the use of the text. 
SOME AMERICAN MEDICAL BOTANISTS 



\title{
SOME AMERICAN MEDICAL BOTANISTS
}

Commemorated in our Botanical Nomenclature

\author{
BY \\ HOWARD A. KELLY, M.D., LL.D. \\ Delivered as a lecture before the Medical Historical Society of \\ Chicago, 1910, and before the University of Nebraska, \\ October 16, 1913

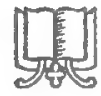

TROY, N.Y.

THE SOUTHWORTH COMPANY, PUBLISHERS

1914 


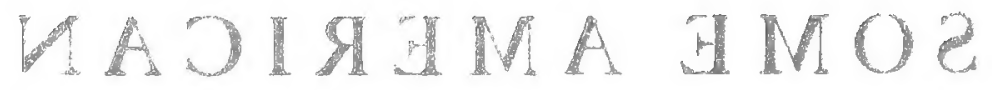

ZTZVATOH IAJIOHM

$\rightarrow K$

26

1429

$35301 \%$

BY

THE SOUTHWORTH COMPANY,

TROY, NEW YORK

$\tau_{B}$ Eord dfaftimore Preas

BALTIMORE, MD, U. S. A. 


\section{DEDICATION}

I am happy in dedicating this work of love to her who inspired me with my first interest in God's natural world, who planned my first fearsome excursions out into the unknown for specimens, who rejoiced in my boyish triumphs and who still continues the inspiration of my riper years-my Mother. 



\section{CONTENTS}

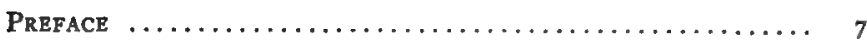

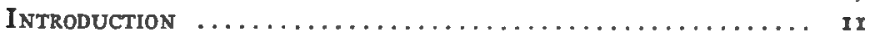

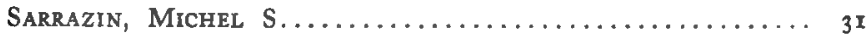

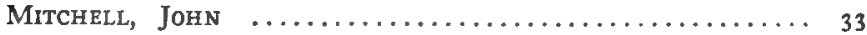

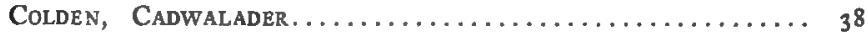

Clayton, John............................... 44

BARTRAM, JoHn.............................. 49

Garden, Alexander............................ 60

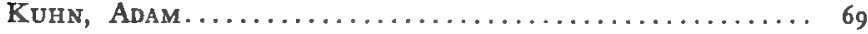

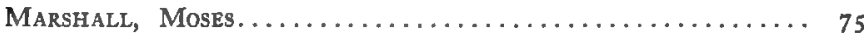

Wistar, Caspar............................ 82

Barton, BenJAMIN SMith....................... 88

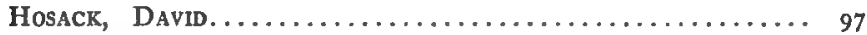

BaLdWIn, WILliam.............................. ro 4

Darlington, William.......................... $\mathrm{II}_{3}$

Macbride, James.......................... 118

BigeLOW, JACOB.............................. I20

Short, Charles Wilkins......................... 129

TORREY, JoHn............................ 136

Pitcher, Zina............................... 145

Pickrring, Charles............................. I5I

RIDDELl, John LeOnaRd......................... 154

Engrlmann, Grorge......................... 157

Chapman, Alvan Wentworth..................... 163

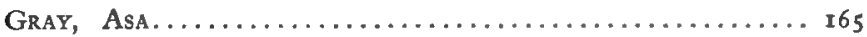

Saxe, Arthur Wellesley...................... 178

Parry, Charles Christopher..................... 180

Howe, Elliot C........................... 187

Herbst, William........................... r 190

Post, Grorge Edward.......................... 192

Rothrock, JosepH Trimble........................ 203

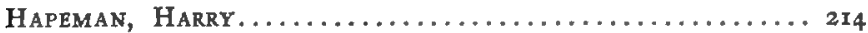






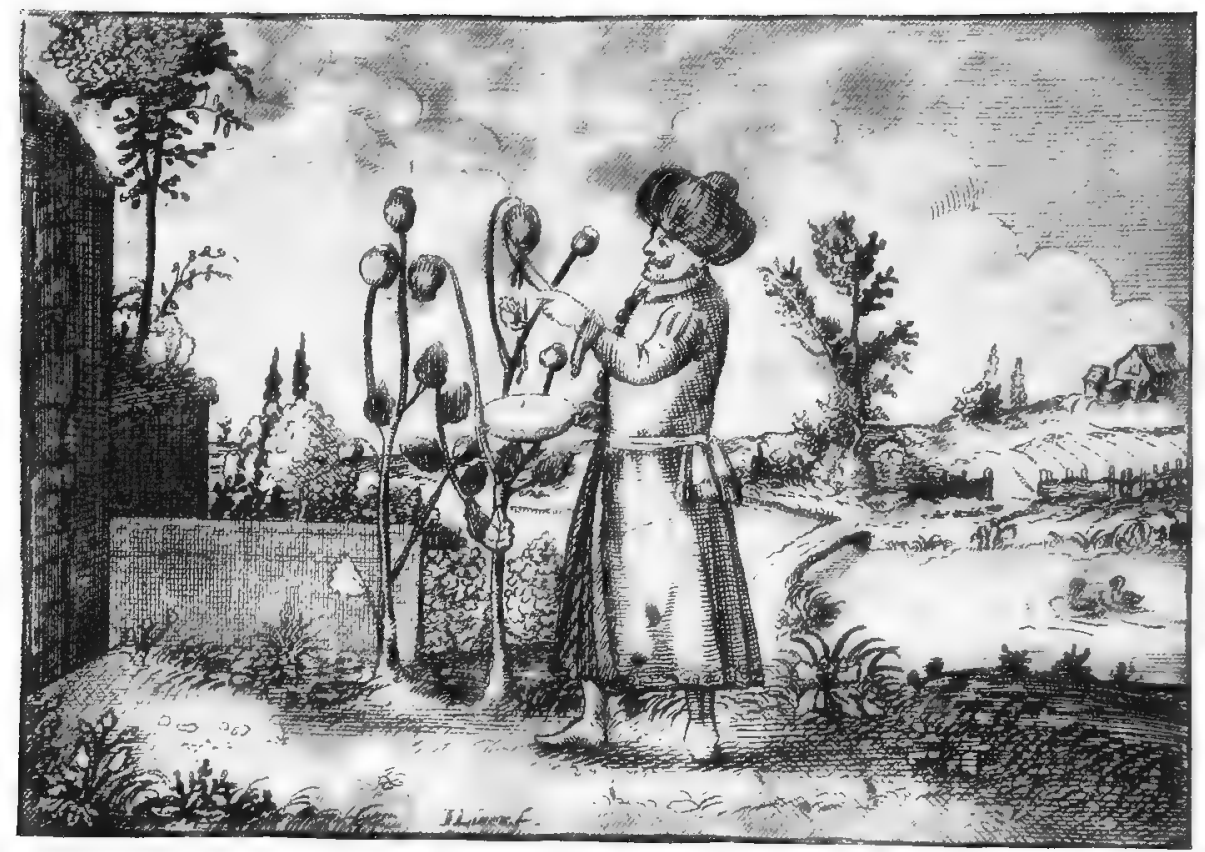

"Incisi fundunt capitella papaveris ex se somniferas lachrymas, Opii sub nomine claras: Illud restituit lapsas in pristina vires exhibitum cautè, \& cluet anchora sacra Medentùm: Sin minus, est gladius, quem gestat dextra furentis."

(From Title-page of George Wolffgang Wedel's Opiologia, Jena, r682) 


\section{PREFACE}

I have written these brief sketches of the lives of some of our great medical forebears who lived in the days when there were giants and when the Anakim lived in the land, in order to while away a few pleasant hours and to wean my fellowdoctors and surgeons a little from the pragmatic spirit of the age. The lives of some of these old worthies led them to lift their eyes daily from nature to nature's God and to recognize in the Bible the same hand that made the floweret, so that Chaucer's accusation "His studie was but litel on the Bible" no longer held. I would that many of their lineal successors were like them in their piety.

My lifelong interest in botany began in the year 1874 , with a warm friendship with Dr. J. P. Crozier Griffith at Upland, Delaware County, Pennsylvania. Later, in 1877 , we were both medical students when I had assumed charge of a Summer School of Natural History at North Mountain, in Sullivan County, Pennsylvania, together with my lifelong friend, Dr. Lewis $\mathrm{H}$. Taylor, of Wilkes-Barre, Pennsylvania. We three botanized in the footsteps of our revered predecessor, that distinguished botanist, Dr. J. T. 
Rothrock. Here, in prosecuting our botanical studies, we broadened our interests to include the ferns. It was in this locality and at this time that Dr. Griffith found the Aspidium aculeatum, variety $B$ raunii, growing in a profusion of beautiful sturdy brown clusters at the falls of a little brook which tumbles down through the shales of the mountain on its way toward the North Branch of the Susquehanna River. As this was a lower habitat than any before noted, it was triumphantly recorded at a subsequent meeting at the Academy of Natural Sciences of Philadelphia. Of the joys of this and many subsequent summers; of the patient hours spent with needles and lens in overcoming difficulties, and the constant thumbing, sometimes of Wood's, but generally of Gray's, analytical keys, with the triumphs of identification of some hundreds of our native plants of Pennsylvania and adjacent states; of trips to New Jersey for Helonias bullata and other treasures, and the thrilling memories of the specialized groups of plants found by the seashore, my old Gray's Botany, with its marginal notes of time and place of finds, continues to bear mute but eloquent testimony. Nor dare I omit to mention here, among the rarities, the beautiful little Pellaea gracilis found growing at Haines's Falls in the Catskills. These were the days when Rothrock was in his prime; when Thomas Mee- 
han and John H. Redfield, ever willing coadjutors of the younger generation, were active in the meetings at the Academy of Natural Sciences in Philadelphia; when Asa Gray, almost the creator of ourNorth American botanical science, was looked up to as the great leader of us all; and when Eaton was cataloguing and figuring the ferns of North America. Times have changed and other interests seem to thrill the boys of today, but neither they nor any subsequent generation will ever discover a passion purer, sweeter and more refining and more exhilarating than the field botanical excursions, followed by the subsequent painstaking closet work of identification, which occupied their fathers and grandfathers. I fear reviewers will accuse me of being somewhat capricious in my selections, for some other names besides those chosen are also worthy of extended notice.

It is a pleasure to acknowledge my debt first of all to Davina Waterson, who has devoted her time and her talents to this work from start to finish for several years, and without whom it could never have been completed; for, although the lives are brief, they have been prepared only after a painstaking search for facts in current journals, in reports, as well as in biographies.

I am glad, also, to thank Prof. J. H. Barnhart, Prof. N. L. Britton, Dr. G. T. Stevens, Prof. Uri 
Lloyd and Prof. Edward J. Nolan for their help in revision.

The book includes medical men, living and dead, who have been honored and immortalized by these floral tributes. I shall be thankful to any one who will help me by adding others. 


\section{INTRODUCTION}

"There is religion in a flower;

Its still, small voice is as the voice of conscience;

Mountains and oceans, planets, suns and systems

Bear not the impress of Almighty power

In characters more legible than those

Which He hath written on the tiniest flower

Whose light bell bends beneath the dewdrop's weight."

I began, once upon a time, to gather some biographical data relative to the floral medical godfathers of such well-known plants as the Gardenia, Wistaria and Claytonia, and this led me holidaying further into the botanical field than I had ever intended to wander. My little flowerbed soon grew into a fair garden of no small size, for there sprang up on all sides the names of many other botanists and flowers clamoring for recognition, until at last my plots and alleys had developed into a stately botanic garden. As I advanced I found my heroes scattered through the centuries, so I proceeded to arrange them in simple chronological sequence. It seemed well, too, to trace the wonderful work of our American pioneer botanists at a time when journeying was truly laborious and often dangerous, and good text-books comparatively scarce. Now, on the completion of my task, I find in my garden such 
a strange medley of plants as I am sure has scarcely ever been seen before. Even an oldfashioned nosegay, plucked at random and dazzling the eye with all the hues of the rainbow, does not present so bizarre an appearance. Here there are gathered within one sacred enclosure, in which the pious may reverently walk and ruminate, the memories of the great demigods of the healing art; flowers from every section of our land, fragrant like Gardenia, and brilliant of color like Poinsettia, lowly like Claytonia and Mitchella, climbing over our houses and drooping their beautiful panicles like $W$ istaria; stately trees of the forest like Torreya and Douglas' fir, and here and there about an old root the fungi of Herbst; and down in the swampy corner of the garden grow Sarracenia and Darlingtonia. I must not dwell longer here upon these honored colleagues who have left behind them these memorials more lasting than bronze. He who will know them better must from time to time foregather with me in the pages which follow.

It is generally agreed that the Canadensium Plantarum aliarumque nondum editarum $H$ istoria, I635, by a French botanist, Jacques Cornuti, was the first book on American botany,

\footnotetext{
${ }^{1}$ Commonly referred to as "Cornut," but his real name seems to have been "Cornuti" in French.
} 



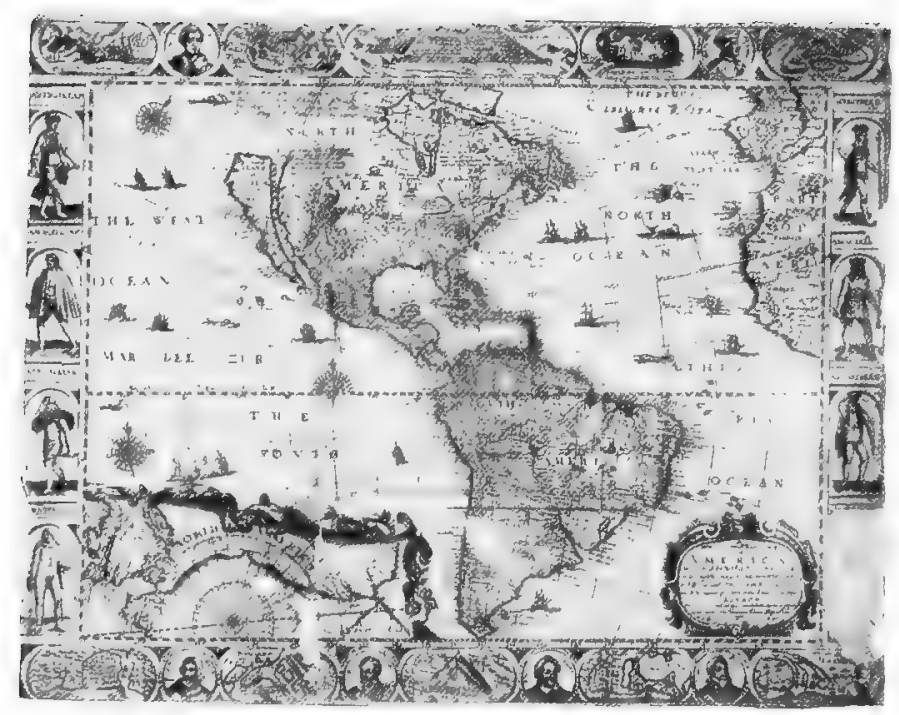

MAP OF THE AMERICAS IN $\mathrm{I}_{6} 6_{3}$

(From the original in the author's possession)

Western coast unknown and the Gulf of California called the Vermian Sea. Lower California represented as an island 
the author writing on specimens sent him from Canada, and it seems probable that Thomas Hariot (or Harriott) (I 560-I62I) was really the first to write on the natural history of America in his Briefe and True Report of the new found Land of Virginia (I590). Harriott was the friend of Raleigh and was sent out by him to America. Two other Englishmen, John Josselyn, living in Boston, and the Rev. John Banister, who came over and settled in America, added to the literature in New England's Rarities, I672, and $A$ Catalogue of Plants $O b$ served in Virginia, I680. The statement that Banister ever travelled, except from England to Virginia (where he settled and remained until his death) appears to be without foundation.

There still exists some of the Botanic Garden made by Dr. John Bartram, about 1730 , on the right bank of the Schuylkill, near Philadelphia. From this garden the doctor sent collections of seeds and plants to his friend Peter Collinson ${ }^{3}$ in London. He also conducted $A$ series of experiments on the Lychnis dioica, illustrative of the doctrine of sex in plants.

I739 saw the publication of the first systematic enumeration of North American plants, edited by Gronovius at Leyden, Holland, to which I have referred in the life of John Clayton.

${ }^{2}$ Peter Collinson, F. R. S., 1693-1768. 
Men in Europe, hearing of the wonderful America where plants, all unnoticed, were growing and blowing and dying and living again, ventured upon a journey fraught with peril and discomfort to discover these treasures for themselves. Thus, Dr. John Mitchell, who came in the early part of the eighteenth century, was able to send Collinson "a paper in which thirty new genera of Virginia plants were proposed," while Peter Kalm, a Swedish naturalist, was spending three years in Pennsylvania and the neighboring states investigating, and, in $\mathrm{x} 753$, publishing his Travels in North America. Dr. Alex Garden, another European, practising in South Carolina, had begun his long and useful correspondence and exchange with Linnaeus and other leading botanists. Dr. Adam Kuhn, of Philadelphia, was probably the first professor of botany in America (appointed I768), and Humphry Marshall founded the second botanic garden, r773, in West Bradford, Pennsylvania. His Arbustum "Americanum (on title-page erroneously "Arbustrum "), published in 1785 , is our first botanical work by a native American. I own a first edition of this in its stout grey paper cover and with its long title, and a note on the last page saying that "Boxes of seeds and growing plants .... are made up in the best manner and at a reasonable rate by the Author." 


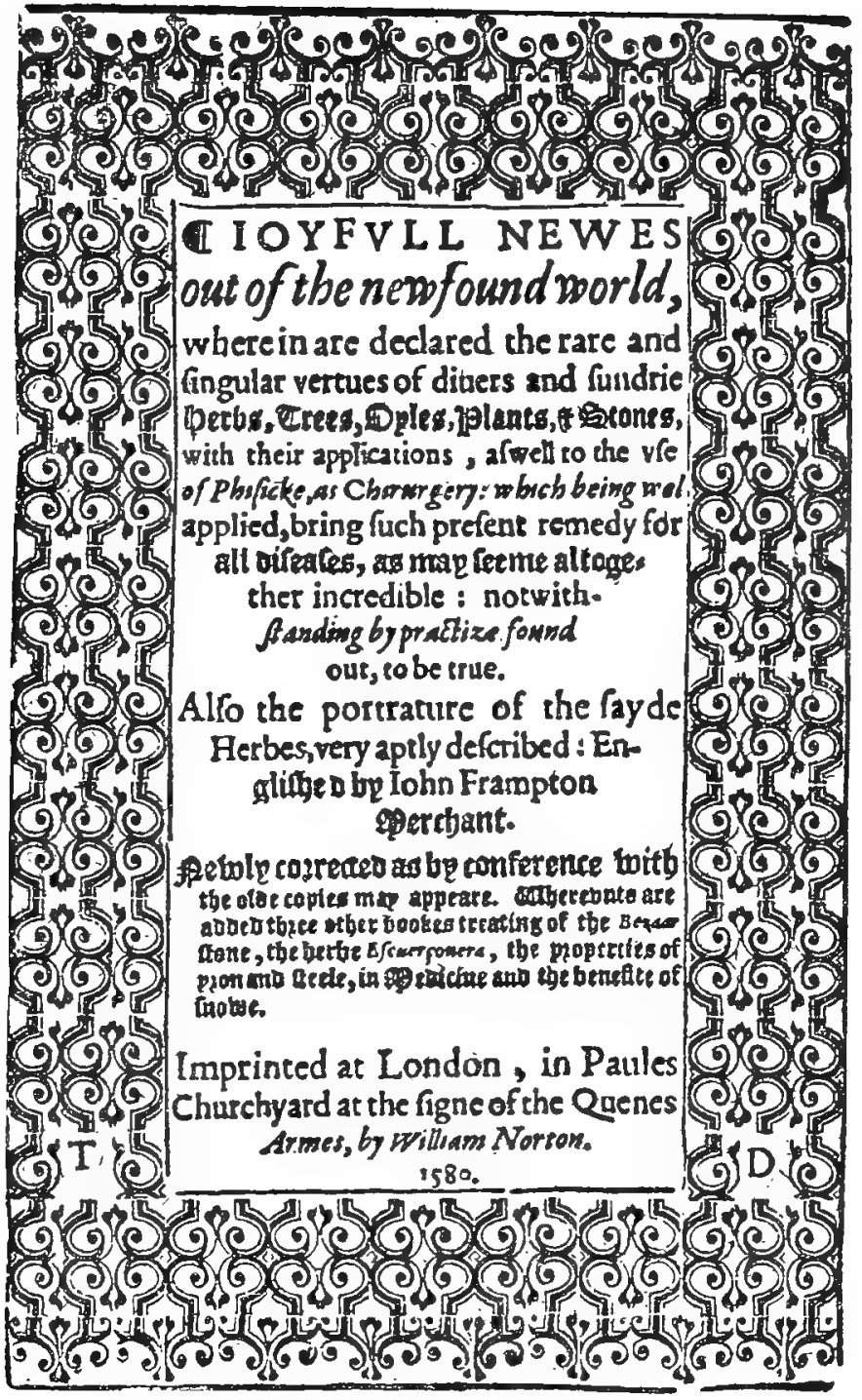

MONARDUS' JOYFULL NEWES 

Dr. Schoepf, a German physician, who spent some years here, published in I787, at Erlangen, an American Materia Medica; and Dr. Benjamin S. Barton followed in the same track with his collections for an Essay towards a Materia Medica of the United States, in 1798, and an Elementary Botany, I803; and Dr. Jacob Bigelow with an American Medical Botany, I8I7.

The Flora Caroliniana, I788, by Thomas Walter and published in London, came between the latter and William Bartram's Travels through North and South Carolina, etc., I79I, first editions of which are rare and costly.

It would not do to except the work of a travelled Parisian, André Michaux, who, in I $80 \mathrm{I}$, gave us his Histoire des Chênes de l'Amérique Septentrionale, nor the younger Michaux's magnificent Histoire des Arbres Forestiers de l'Amérique Septentrionale, I81o, with colored plates; and with these two names must be bracketted those of the Rev. Henry Muhlenberg, of Lancaster, Pennsylvania, who made a fine Catalogue of the hitherto unknown Plants of North America, I8I 3 , and Frederick Pursh, the English botanist, who published his Flora Americae Septentrionalis, 18 I4.

About this date, and shortly after, came several works on state and local flora, notably Bigelow's Florula Bostoniensis, I 814; Stephen 
Elliott's Sketch of the Botany of South Carolina and Georgia, 1816; Dr. W. P. C. Barton's Philadelphia Flora, I8r8; and Dr. John Torrey's Catalogue of Plants growing within Thirty Miles of the City of New York, I819, a collaborated work. The year before had seen the birth of Thomas Nuttall's Genera of North American Plants, an epoch-making volume.

Dr. W. P. C. Barton, again, in the same year, feeds the botanical flame with a Flora of North America including original painted drawings. "This," says Darlington, " though entirely without method, was tolerably well executed and extended to three volumes quarto, when it was discontinued." Torrey, also, in I 824, left a useful paper partly incomplete-his Flora of the Northern and Middle Sections of the United Statesbut that on The Rocky Mountain Plants, 1826, the first American specimen of a regular Flora arranged according to the Natural System, was "indeed an admirable performance." The modest bibliographer, William Darlington, then adds, without a comment, his own Florula Cestrica, I826, and goes on to speak of some articles in the tenth volume of the American Journal of Science by Dr. Lewis C. Beck, Contributions toward the Botany of the States of Illinois and Missouri, I 826, then breaks into warm praise of Sir William Hooker's Flora Boreali-Americana, I 829-I 840 , with its 238 quarto plates. 
Two more Flora now appear, the Prodromus Florae Columbianae of Dr. J. A. Brereton, 1830, and, shortly after, Dr. C. W. Short's paper, Florula Lexingtoniensis, these heralding a bigger piece of work by Beck on Botany of the Northern and Middle States, I 833. The Rev. L. D. von Schweinitz followed with an elaborate paper on Synopsis of North American Fungi, 1834, and the year was also notable by the fact that Dr. Asa Gray issued his first paper, $A$ Monograph of North American Rhynchosporae. Dr. John L. Riddell published his Synopsis of the Flora of the $W$ estern States in 1835, Gray appearing again, this time with Dr. John Torrey, to rejoice the student with their Elements of Botany, 1836 , followed in 1838 by a work which became a stand ard authority, the Flora of North America. In between these two books came Gray's Revision of the North American Melanthaceae, Darlington's Flora Cestrica and Dr. W. E. A. Aikin's Catalogue of Phaenogamous Plants and Ferns Growing in the Vicinity of Baltimore.

Dr. George Engelmann is the next botanist on the list, with his Monograph of the North American Cuscutineae, 1842 , Torrey pressing on behind in 1843 with " two ponderous quarto volumes, embellished with I6I colored plates" on the Flora of the State of New York. Dr. Alvan W. Chapman made a useful List of Plants growing 
in the Vicinity of Quincy, Florida, and Gray, with W. S. Sullivant, published a beautiful little work on the Mosses of the Alleghanies, both works coming out in 1846 .

Pioneer work has been shown making rapid advances into volumes even now esteemed as classics. Every botanist uses Gray's Manual of Botany, i 848 , which has gone through so many editions, and some may be fortunate enough to possess a first edition of his first volume of Genera Florae Americae Boreali-orientalis, Illustrata, 1848, "designed to illustrate by figures and analyses, the genera of the plants of the United States."

It has been difficult not to write also concerning English medical botanists whose scientific and social life touched so closely on that of congenial fellow-workers in America. The names of two men, John Coakley Lettsom (I744-1815) and John Fothergill (1712-1780), figure constantly in the records of our early medical colleges, and in the correspondence of our pioneer botanists. Fothergill was constantly consulted as to the choice of books to be sent over here, and gave generously to any doctor who coveted the specimens in his botanical garden. "The younger Linnaeus distinguished a plant of the class Polyandria digynia, natural order Hamamelaceae, by the name of Fothergilla" (Darlington), and was 


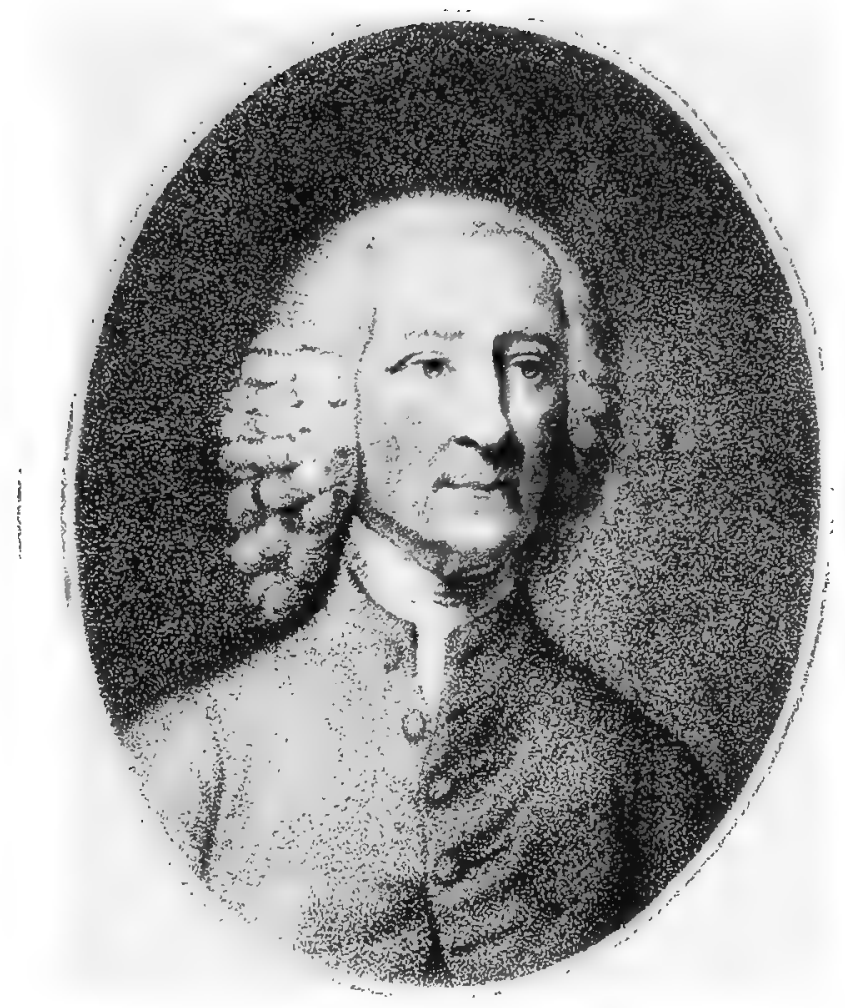

JOHN FOTHERGILL, M. D., F. R. S.

I 7 I 2-I 780

(From a bust belonging to Dr. Lettsom) 



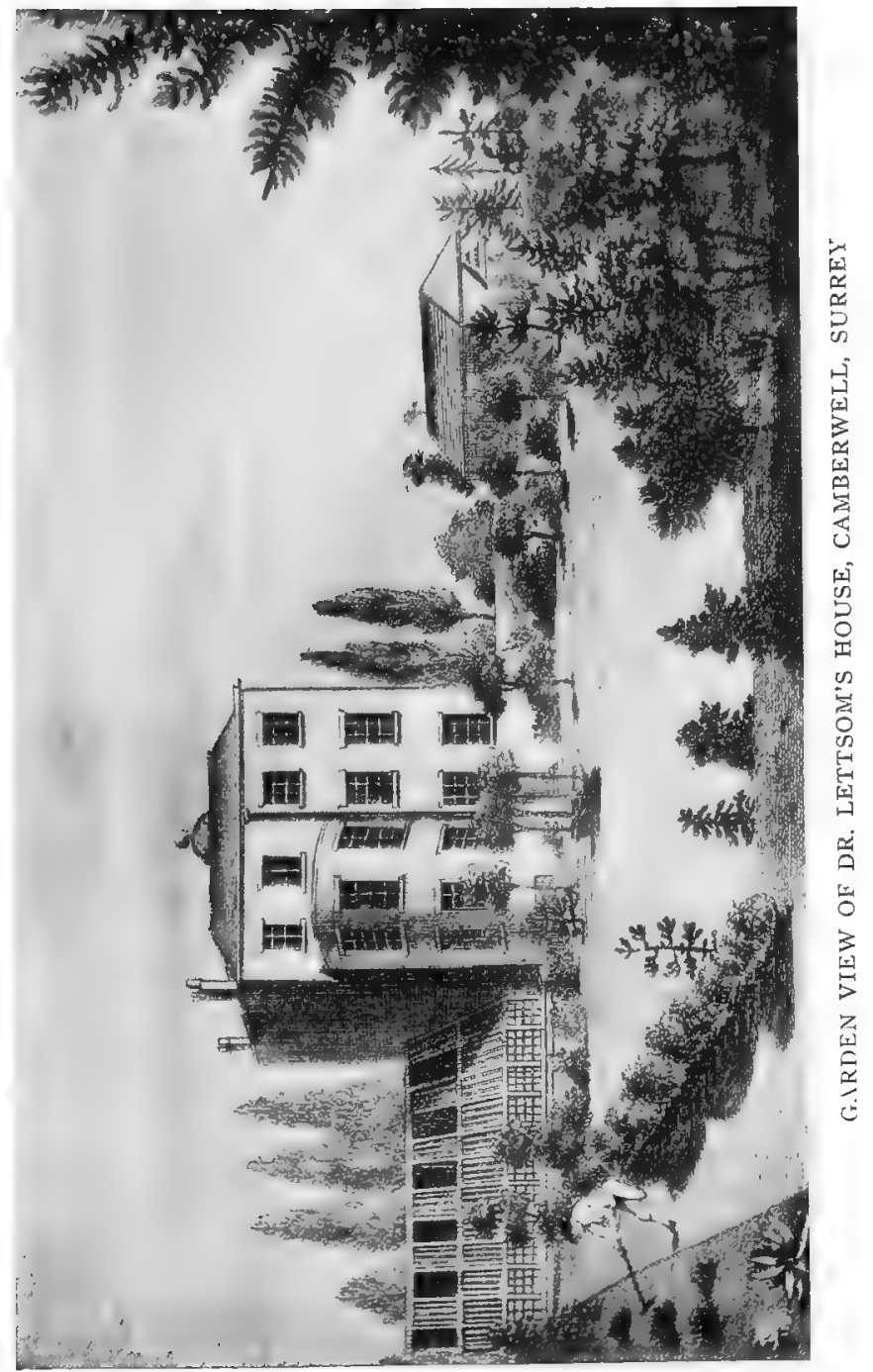





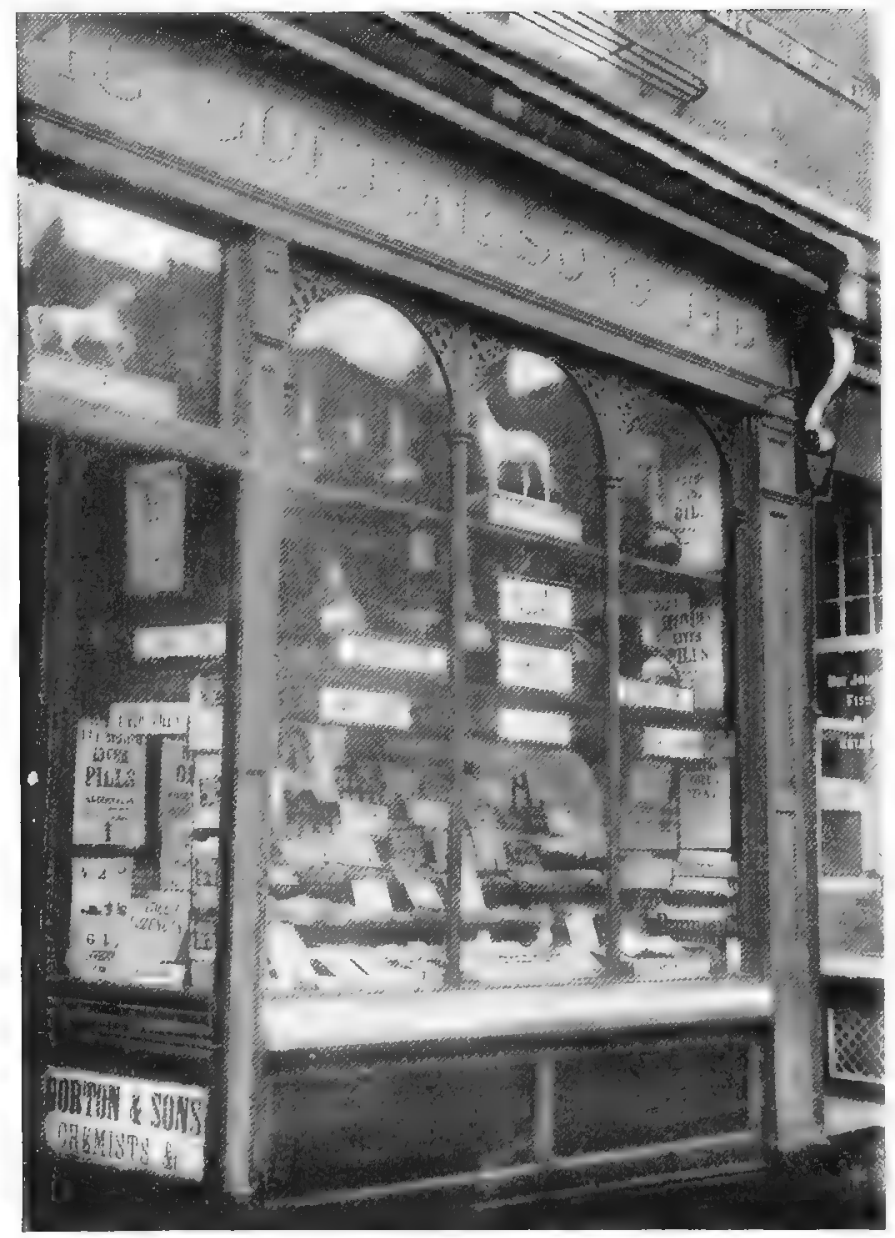

DRUGGIST'S SHOP IN WHITECHAPEL, HIGH STREET, WHERE "LETTSOM'S PILLS" ARE STILL SOLD 
intimate with Lettsom, who began his medical work under Fothergill, and like him, spent many pleasant hours in writing to Humphry Marshall and John Bartram in Pennsylvania. Lettsom had a genus (Lettsomia) named after him. I had the good fortune to find in Whitechapel High Street, London, a little druggist's shop where "Lettsom's Pills" are still sold, and the proprietor gave me one of the original advertisements, which he had found on a street vendor's barrow one Saturday night, also allowing me to get a picture of Lettsom's house near London from an old engraving hanging in his back parlor.

The English names at this time crowd fast, and folios of retrospective writing would not do them justice; so, leaving the pioneers, I pass on to a curious field of inquiry-the personal nomenclature of plants.

Distinct epochs of thought concerning the preeminence of tutelar gods, the merits of sovereigns and saints and scientists in the mind of botanists, can be traced in plant nomenclature. Narcissus and Hyacinth are dear and familiar. Of Narcissus, son of Cephissus and Lirope of Bœotia, it was foretold that he should live happily until he saw his own face. One day, heated with hunting, he came to drink at a stream and saw his own reflection. After this he pined away and was 
changed into a flower; when the Naiads sought his body

"Instead whereof a yellow flower was found, With tufts of white about the button crown'd."

Hyacinth shared a like fate: the beautiful son of Amyclas, King of Amyclae in Laconia, and Diomede, he was killed through jealousy by Apollo while the two were playing at quoits on the banks of the Eurotas. From his blood the god caused the hyacinth to spring, bearing on its petals the exclamation $\mathrm{Ai}$ (woe!).

Artemisia bears one of the names of Diana, who was specially venerated of young girls, who sacrificed their hair to her before marriage. She was equally renowned for healing and for swift killing, and found the properties of the Artemisia and gave it to her devotees to alleviate menstrual pain. The leaves of this plant are still gathered and dried for this purpose by the peasants in France and Algeria.

The Telephium is called after Telephus, King of Mysia, son of Hercules and Auge, but any direct connection is, apparently, undiscoverable; and the genus Euphorbia was so called-some aver-by Linnaeus, after Euphorbus, physician to Juba II, King of Mauritania, circa B. C. I9; but Salmasius (1588-1653), a French botanist, mentions the name, so Linnaeus could not have been the sponsor. 
Our pretty little "blue-eyed gentian," which "lifts its fringed lids to heaven," takes its name from Gentius, King of Illyria, who first experienced the virtues of the plant, and Eupatorium Pliny gives as the cognomen of Mithridates (13263 B. C.), King of Pontus, who discovered its virtues.

Saints came in for their full share of floral children; this naming probably arose in days when, from the monastery gardens, plants were gathered to concoct the gruesome mixtures administered by priestly hands to the sick poor. Herb St. Anthony, St. John's Wort, St. Christopher's Herb, St. Ignatius' Beans, St. Martin's Herb are some, while more are given by Jean Bauhin in De Plantis a Divis Sanctisve Nomen habentibus, I 591 .

The endurance of flower and tree as a monument seems to have occurred to most botanists, especially in the days when might was right and the tenure of land, houses, and life itself extremely uncertain. The little annual, bearing a fellow scientist's name, knew no destruction in its perpetual renewal. The huge tree, victim of storm and fire and man's desire, was safe in plantation over half a world, and the delicate Spring Beauty (Claytonia) would spring half shyly, half mockingly in the neglected graveyard where proud family monuments sunk lop-sidedly into 
the graves of the men they were intended to commemorate forever.

Thus, in letters of Conrad Gesner, the Swiss naturalist, it is shown that, had he lived to finish his Histoire des Plantes, he would have perpetuated the names of many friends, as he asked them -Bauhin among the number-to choose among his newly found plants for a namesake or to allow him the pleasure of choosing for them.

Clusius," himself known as Clusia (Plumier), "called the Contrayerva of the shops" Drakena in honor of his great friend Sir Francis Drake," and for a long time mutual compliments of this kind followed, Tournefort, ${ }^{\circ}$ Plumier, and Petiver, ${ }^{8}$ being specially given to the practice. In Plumier's Nova Plantarum Genera, I703, giving a description of Io6 new genera he names some 50 after well-known botanists, seven of them English: Gerardia, Morisonia, Parkinsonia, Petiveria, Plukenetia, Sloanea, Turnera.

John Lindley, writing in his Vegetable Kingdom ( 1846 ), remarks that: "Since the days of

${ }^{8}$ Conrad Gesner (1516-1565). Opera Botanica, 1753-1759.

${ }^{4}$ Charles de l'Écluse, r 526-1609, celebrated doctor and botanist.

- Dorstenia Contrayerva. (Used to be mixed with crab's eyes, as a remedy.)

${ }^{6}$ Joseph Pitton de Tournefort, 1656-1708, royal botanist, I683.

'Charles Plumier, I646-1704, scientist and botanist. Description des Plantes de L'A mérique, 1695.

${ }^{8}$ James Petiver, M. D., I660-I718, doctor and botanist. Pterigraphia Americana ..., r7 I2. 
Linnaeus, who was the great reformer of this part of Natural History, a host of strange names, inharmonious, sesquipedalian, or barbarous, have found their way into botany, and, by the stern but almost indispensable laws of priority, are retained there. It is full time, indeed, that some stop should be put to this torrent of savage sounds, when we find such words as Calucechinus, Oresigenesa, Finaustrina, Kraschenninikovia, Gravenhorstia, Andrezejofskya, Mielichoferia, Monactineirma, Pleuroschismatypus, and hundreds of others like them thrust into the annals of botany without even an apology. If such intolerable words are to be used, they should surely be reserved for plants as repulsive as themselves, and, instead of libeling races so fair as flowers, or so noble as trees, they ought to be confined to Slimes, Mildews, Blights, and Toadstools. The Author has been anxious to do something to alleviate this grievous evil, which, at least, need not be permitted to eat into the healthy form of botany clothed in the English language." And Gray, writing to George Engelmann in I843, says: "I agree with you generally in the impropriety of too much multiplying names of species after the collectors, etc., yet I think these are good names, easily remembered and particularly advisable in very large genera. My practicable rule is to name such species after the discoverer, etc., 
if I cannot find any really pertinent characteristic name unoccupied."

From this time on, the complimentary naming of plants seems universal, Linnaeus "taking the lead in amical floral nomenclature. When he had as guest or disciple any one heartily and studiously interested in botany, he often dedicated a new genus or species to him. Adam Kuhn, his pupil and America's first professor of botany, getting the Kuhnia Eupatorioides.

The names come crowding on-Dahl, Lobel, Fuchs, ${ }^{10}$ Wistar, Garden, Bauhin, Magnol, Grew, ${ }^{18}$ Gloxin, Fothergill, Lettsom, Kamel, ${ }^{14}$ etc. -and sometimes proper names with prefix or suffix evoked angry expostulation from botanical writers who objected to Vaseyanthus, Pringleophytum, Neonelsonia and Paleohillia! "It was Dr. Otto Kuntze," says Professor Pollard, "who astonished the world and carried off the palm in this class by the establishment of such genera as 'Sirhookera' and 'Peckifungus.' "'

"Carl Linnaeus, M. D., Sweden, I707-r778. ("Carl von Linne," after 1757 .)

${ }^{10}$ Leonard Fuchs, M. D., Swabia, x $50 x-1566$.

"Caspar Bauhin, M. D., Basie, r 560-I624.

${ }^{19}$ Prof. Pierre Magnol de Montpellier, I638-r7I5. Brought the Magnolia to France.

${ }^{18}$ Nehemiah Grew, M. D., London, r64r-1712.

${ }^{14}$ Geo. Joseph Kamel or Camellus, I66r-I706. A Moravian Jesuit, botanical traveller in Asia. He brought the Camelia japonica to France.

${ }^{18}$ Science, August 23, $19 \mathrm{Ir}$. 


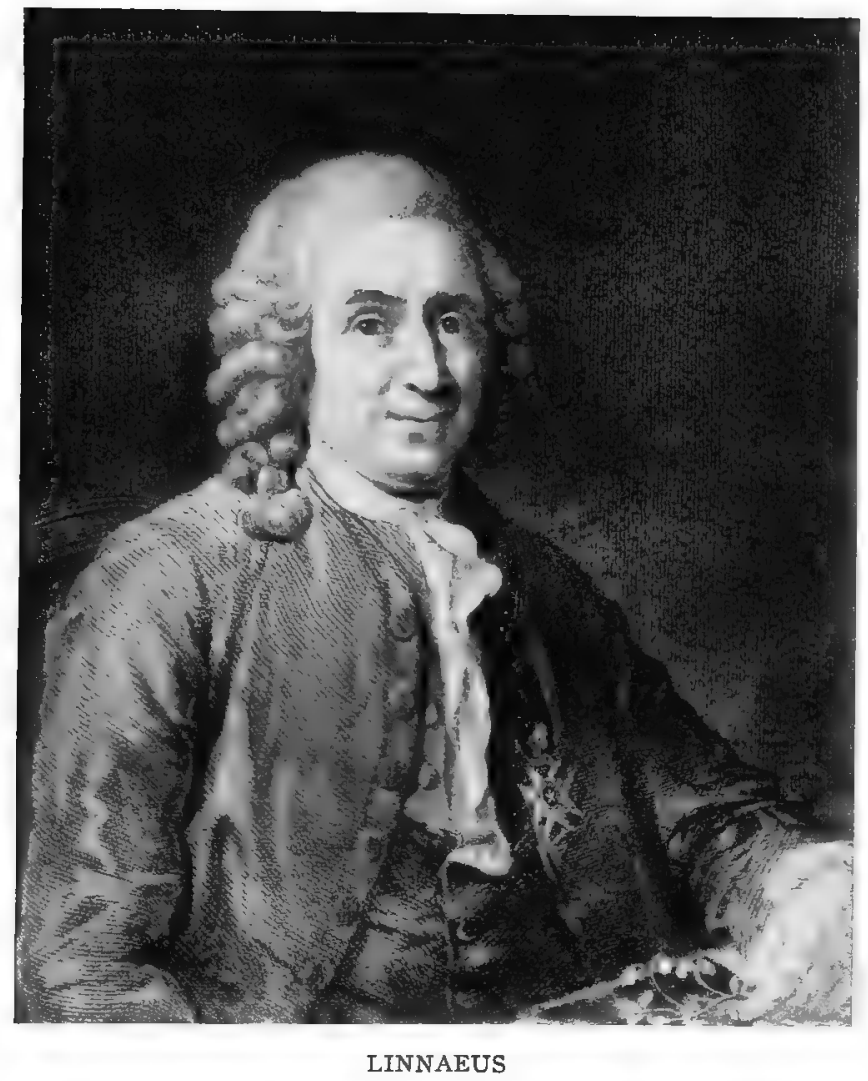

(From a painting in the Royal Academy of Science, Stockholm) 

It might also be questioned whether it is fair to burden any plant with such a discordant name as Eschscholtzia (Chamisso). ${ }^{10}$

Linnaeus complains "that "Botanists seem (to me) never to have touched upon nomenclature as a study. .... Nothing is more certain than that the whole stock of specific names are erroneous "; and Professor Pollard ${ }^{18}$ gives some names which fail to be complimentary because misspelt: Wisteria-Wistar (Nuttall), Lechenaultia ${ }^{10}$-Leschenault ${ }^{20}$ (Brown), Scoria for $\mathrm{H} \mathrm{i}$ coria ${ }^{21}$ (Rafinesque).

"The credit of having reformed the nomenclature of genera by the exclusion of names made of two distinct words has been given to Linnaeus, but Brunfels ${ }^{22}$ had inaugurated the reform 220 years before Linnaeus published his Philosophia Botanica." 27

In early days plants sent from America evoked pretty letters from European botanists asking permission to name a genus after the sender, and

${ }^{18}$ Johann F. Eschscholtz, I793-1831, M. D. and botanist.

${ }^{17}$ Correspondence of Linnaeus, vol. ii, p. $25^{8}$.

${ }^{18}$ Op. cit.

${ }^{10}$ Lindley (The Vegetable Kingdom) has the correct spellingLeschenault. (Brown.)

${ }^{20}$ A French botanist and traveller.

${ }^{21}$ Barton has Scoria and Hicoria, two plants.

${ }^{22}$ Otto Brunfels, M. D., in Berne, I500-I534.

E. L. Greene. Landmarks of Botanical History, 1909. 
such men as Bartram, Marshall or Garden in America would frequently despatch a plant to which they had already given the name of their European co-workers in the botanical field; so the study of plant nomenclature, even during one short half-century, yields a delightful harvest concerning the intimate life of scientists on two continents.

One of the first reuniting links between England and the Pilgrim Fathers was a floral one. Confronted at the outset with epidemics incidental to acclimatization and poor sanitation, the few doctors in America eagerly scanned the ponderous herbals they had brought over and searched the country in hopes of finding the wellknown febrifuge and other remedies they had used in the old country. Ship's captains were given letters to friends asking for plants and seeds required, but these, received after interminable delays, had to be very carefully tended. In searching for remedies, many new and wonderful plants were discovered and sent as specimens or exchanges to the great European botanists, arousing their eager interest in the new country and a great desire to have such plants in the botanic gardens then flourishing.

Boerhaave "at Leyden was in the habit of making large exchanges, and Dr. Fothergill, ${ }^{25}$ who

${ }^{21}$ Hermann Boerhaave, M. D., I 668-1738.

${ }^{25}$ John Fothergill, M. D., 1712-1780. 


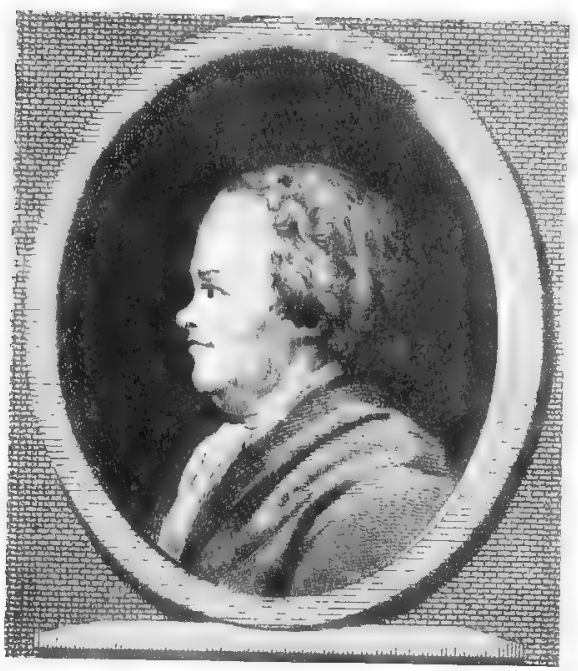

HERMANN BOERHAAVE

(From an engraving, 1788) 

sent us the anatomic pictures in the museum of the Pennsylvania Hospital, had 4000 plants in his botanical garden near London. Dr. John Mitchell, who came over to Virginia in 1700 , sent plants to Linnaeus and to Bartram, and in 1763 refers to the "white double daffodil " brought over by the first settlers. American oaks planted centuries ago still flourish in England while $W$ isteria and "Virginia creeper" still climb over the walls of hundreds of houses in foggy London. Sponsorial compliments abounded in floral godchildren such as the Mitchella, Gardenia and Bigelowia, which were as tenderly reared in Europe as were the Boerhaavia, Meadia ${ }^{2 T}$ and Lobelia in America.

There were anxious periods of waiting, for a voyage of seventy days or more wrought havoc with plants, insects and reptiles. Even war did not upset botanical sympathies, and the published correspondence in times of warfare and Indian raids shows chiefly anxiety lest, a ship being captured by the enemy, seeds and plants should be thrown overboard. Michaux, ${ }^{28}$ the great botanist, speaks of the French Revolution ( 1789) merely as a hindrance to his gathering specimens abroad.

${ }^{20}$ Perhaps our American Wisteria is cultivated in England, but the common species there, as here, are of Chinese or Japanese origin. (Greene.)

${ }^{27}$ Richard Mead, M. D., London, I673-r754.

${ }^{23}$ André Michaux, botanist and explorer, 1746-1802. 
John Bartram, in $176_{3}$, laments that a government scheme of exploring Louisiana cannot be carried out because the scientists would be exposed to "the greatest savage cruelty of the gun, tomahawk, and torture" by the Indians. He did venture once with a guide, but says, "An Indian met me and pulled off my hat in a great passion and chawed it all around to shew me how he would eat me if I came again."

There was sometimes, however, bloodless warfare in the botanical camp in disputation over the alleged medicinal merits of certain plants. Lawrence van de Veer, of New Jersey (about I796), cures 400 hydrophobia patients with the Scutellaria lateriflora. Dr. Lyman Spalding first praises it, then later wishes "to be stricken from the list of believers," while Barton of Philadelphia condemns him for believing in it at all. Dr. John Tennant, ${ }^{30}$ an enthusiastic botanist of Virginia, swears by Seneca snakeroot for pleurisy, against all disputants. The experimenter and botanist, Dr. Samuel Thomson, later uses Lobelia inflata in his "Thomsonian System" for nearly every evil, and creates endless opposition. But the search for remedies was keen in days when malaria and dysentery ravaged whole towns and paralyzed industry.

${ }^{20}$ Lyman Spalding, M. D., New Hampshire, 1775 -r82x.

${ }^{30} \mathrm{John}$ Tennant, M. D., Virginia, circa 1736. 
It was tempting to linger over the biographies of these early botanists, but my little oeuvre d'amour was only to include the floral godparents; otherwise some two or three volumes would hardly have sufficed.

The first botanist I would introduce to you is Michel S. Sarrazin. 



\section{MICHEL S. SARRAZIN$$
\text { I659-I } 734
$$

Sarracenia purpurea-TOURNEFORT

Canada and the United States join hands in the order Sarraceniaceae, the well-known Pitcher Plants, Dr. Sarrazin of Quebec gathering the "side-saddle flower" which flourishes in the bogs of North America, and Dr. Darlington being commemorated in the Darlingtonia, of California.

There seems to be some confusion among the botanists as to which Sarrazin the plant Sarracenia was named for. It was first named and described by J. B. Tournefort in Institutiones rei herbariae, second edition, Paris, I7oo, thus: "Sarracenia canadensis foliis cavis et auritis. Sarracenam appelavi a Clarissimo D. Sarrazin, Medicinae Doctore, Anatomico et Botanico Regio insigni, qui eximiam hanc plantam pro summa qua me complectitur bene volentia e Canada misit." Linnaeus, in his Genera Plantarum, I753, established the genus, ascribing it to Tournefort.

No initials are given to this Sarrazin, and many have assumed that a Dr. Jean Antoine 
Sarrazin is meant. But Jean Antoine was born in Lyons, France, April 25, I 547, and died there November 29, 1598. As he went out of the world ten years before Tournefort came into it, he manifestly did not send the flower to Tournefort.

Michel S. Sarrazin, undoubtedly the real sponsor, was both physician and naturalist. Born in 1659 , he went to Canada in 1685 , and becoming noted both as doctor and scientist, he had the honor of being elected member of the French Academy. Moreover, several years after his arrival in Canada he was appointed King's Physician for the country, the only bearer of that title in all New France. His salary was a bare 600 livres, without recompense from his patients.

It is a thousand pities that we have so few data touching this interesting life. About I7I2 he married Marie Anne, the daughter of François Hazeur, fils, and had seven children. He died in Quebec, September, I734, and his widow received a pension from the King; his sons, who were regarded as protégés of the State, were then studying medicine in Paris. 


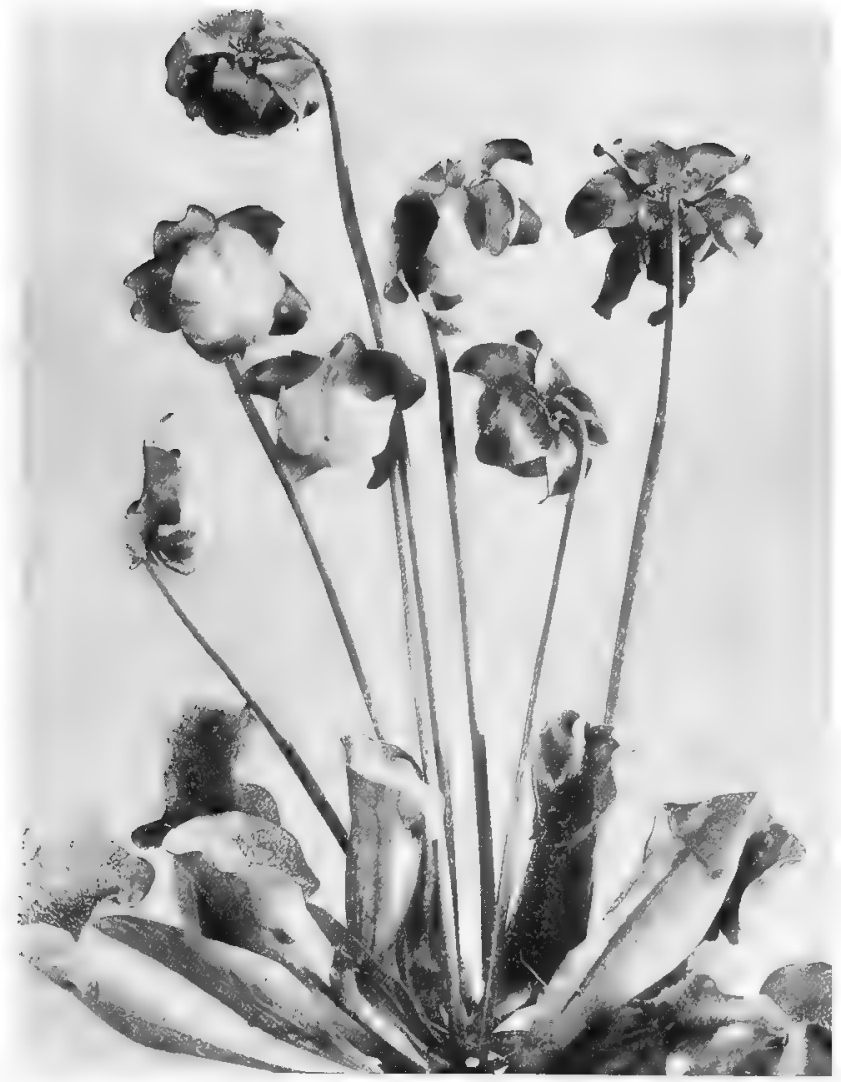

SARRACENIA PURPUREA. COMMON PITCHER PLANT (From the J. Horace McFarland Nurseries) 



\section{JOHN MITCHELL \\ I680?-I 768}

\section{Mitchella repens-LINNAEUS}

Much research into old biographical and botanical works resulted in failure to find in any details of John Mitchell's early life. Scotch by name, he may also have been a reservist of an ultra-Scotch type and told little of his life to his American friends. Three letters in the Correspondence of Linnaeus show him to have been a fellow of the Royal Society, and, piecing other items together, it is certain that he was born and educated in England and did take a medical degree.

About I700 he came over to America, settling on the Rappahannock River, near Richmond, Virginia, being one of the earliest chemists and physicists in this country. It is assumed that he practised medicine, and the amount of writing on botanical and other subjects may have been the result of unusually healthy neighbors and much leisure. His Dissertatio brevis de Principiis Botanicorum was dated Virginia, 1738, and dedicated to Sir Hans Sloane. Three years later 
34 SOME AMERICAN MEDICAL BOTANISTS

appeared his Nova Plantarum Genera, dedicated to Peter Collinson, ${ }^{1}$ both of which papers were printed at Nuremberg, i 769. Collinson was very keen on making exchanges of natural history specimens with Americans, and strongly urged them to cultivate silk, flax, hemp and wine. Mitchell must have enjoyed having such an interested friend in the old country, and would anxiously await from him the opinion expressed by the Royal Society concerning a paper on The Causes of the Different Colours of People in Different Climates ( I743), which Collinson was to read for him, in I744. The paper finally appeared in the Society's Philosophical Transactions (vol. xliii).

However, in 1746, Mitchell was himself in London. He had had a bad journey, for the ship was captured by Spanish pirates, and Linnaeus, writing to Haller ( 1746 ), says:

"All the plants sent me from New York have fallen into the hands of the Spaniards, along with those that Dr. Mitchell has for many years been collecting in Virginia. He himself is returned safe, though in a desperate condition, to England.

"I have lost, in the same ship, numerous specimens and descriptions sent by Governor Colden from New York."

\footnotetext{
${ }^{1}$ Peter Collinson, naturalist and antiquary, $1694-1763$.

' Correspondence of Linnaeus, vol. ii.
} 
Mitchell himself, writing to Linnaeus from London, I748, tells him: "I should have been happy to send you a few plants if they had not been so much damaged by pirates as well as injured by their sea voyage, so that, among more than a thousand specimens, I have scarcely a perfect flower.

"The descriptions I drew up, of new genera of plants, have been sent by Mr. Collinson to persons in various parts of Europe, so that I scarcely know now where to get a copy.

"Mr. Trew, to whom Mr. Collinson sent a few papers of mine, informs us that they have appeared in the last volume of the Nuremberg Transactions. They consist of a dissertation on a new botanical principle derived from the sexual theory, which, I think, accords with your ideas, and, if I mistake not, our systems support each other."

On the I 7 th and 24th of November, I748, he read a paper before the Royal Society on The Preparation and Use of Various Kinds of PotAsh (Phil. Trans., xlv). The learned gentlemen of the Society were quick to recognize the merits of their returned countryman and made him a fellow on December i 5 of that same year. He would, doubtless, spend a good deal of his time in the Botanical Garden at Kew, indeed, would seem to have lodged nearby, for he dates a paper 


\section{SOME AMERICAN MEDICAL BOTANISTS}

from Kew, 1759, written for the Philosophical Transactions, entitled, $A$ Letter Concerning the Force of Electrical Cohesion.

Linnaeus named the familiar and beautiful little checkerberry, Mitchella repens, after him, and kept up a constant and affectionate interchange of letters. The last of those from Mitchell are dated $\mathrm{I} 75^{\mathrm{I}}$, one to Linnaeus, one to Bartram, and this date would make one conclude that he never returned to America, as no letters seem extant after I75 I from the new country. To Bartram he says:

"I have had so much business of that kind (writing) upon my hands since I came to England, that I have contracted a disorder by it, which makes me unable to pursue it any longer or even to sit down to write a letter, especially one that requires any thought, without being sensibly the worse for it." He died in March, I768, though where I cannot discover.

There is some more of his work which ought to be mentioned, notably, $A$ Map of the British and French Dominions in North America, London, I755, which is said to " mark an era in the geography of North America," and was quoted in boundary negotiations. A French copy was published at Paris, 1756 , and a second English edition appeared in 1757 ; reprinted, 1782 ; the British Museum is the fortunate holder of copies. His 
Contest in America between Great Britain and France, by an Impartial Hand, came out in London, I757, also The Present State of Great Britain and North America, 1767. Among his MSS., found after death, was An Account of the Yellow Fever which prevailed in Virginia in 1737 , $I 74 I$ and $I 742$, in letters to Cadwalader Colden and Franklin. These were published, with the replies, by Rush in the American Medical and Philosophical Register, vol. iv.

Amer. Med. Biog. Thacher.

Amer. Med. \& Philos. Reg., vol. iv.

Stephen's Dict. of National Biog.

Contributions to the Annals of Medical Progress. J. M. Toner.

Pulteney's Progress of Botany, vol. ii.

Gentleman's Magazine, r 768. 


\section{CADWALADER COLDEN I688- 1776}

\section{Coldenia procumbens-LINNAEUS}

A link in the botanic chain is a young Scotch doctor, "a truly great philosopher and a very great and ingenious botanist," who came to be Lieutenant Governor of New York. This was Cadwalader, son of the Rev. Alexander Colden, minister in Dunse, near Edinburgh, born February $\mathrm{I} 7, \mathrm{I} 688$.

His father, probably a learned and leisured man, personally directed the boy's education, then sent him to Edinburgh University, where he graduated M. D., in 1705 . During the three following years he devoted his attention "to medicine and mathematical science"-in the quiet little town of Dunse I should imagine. The news which came, from time to time, of William Penn's colony found an eager hearkener in young Colden, and the next definite information is that he practised successfully in Pennsylvania from I 708 to I7I 5 .

Possibly about this time he recalled the great facilities for studying and gaining experience in surgical work which existed in London and Edin- 


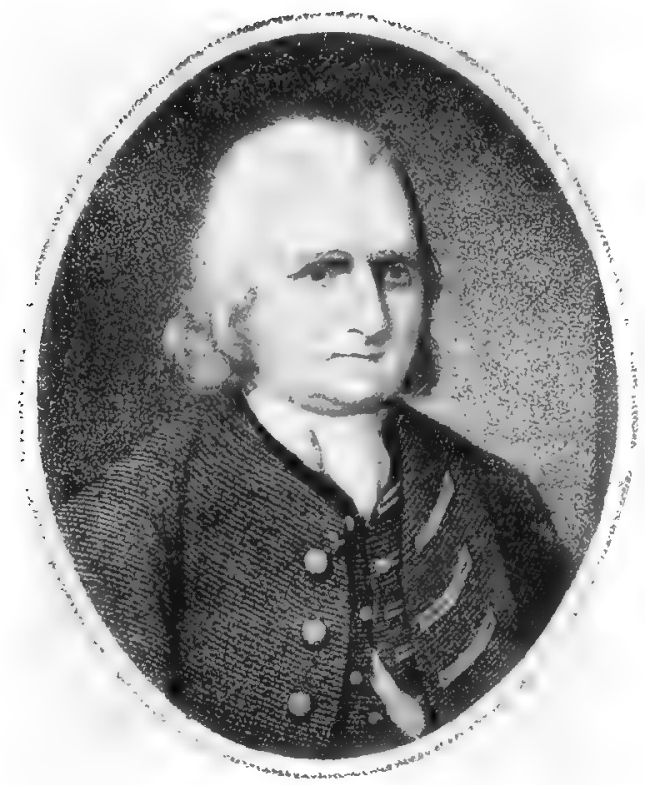

CADWALADER COLDEN

(From a painting in the possession of C. D. Colden) 

burgh, and he may have wanted to freshen his wits and also to see his friends-one friend in particular, Alice Christie, whom he married the year of his arrival in England, at Kelso, November II, I7I5. There must have been great lamentation in the families of Christie and Colden when, the following year, young Cadwalader decided to return to America and take his Alice with him. Doubtless he also took cases of books, instruments and drugs when he embarked for the tedious voyage of some months' duration.

While in London he was introduced to Dr. Edmund Halley, who was so impressed with a paper Colden had written on Animal Secretions that he had him read it before the Royal Society, and made the writer acquainted with many and learned men, who became his good friends and correspondents.

In 1718 he settled in New York, but soon ceased to practise and became more of a public character, being Surveyor-General for the State in 17 I9 and Lieutenant-Governor in 1761. Before this latter appointment he obtained a patent for a tract of land in Orange near Newburgh, which he called "Coldengham." Here he lived from 1728 to 1760 , and in New York City from I 760 to 1763 or I764, when he built and occupied a large house on Long Island, near Flushing, until his death on September 28, I776. 
Colden's public duties did not loosen his grip on science. Much of this knowledge was used in speech and by pen during an epidemic of fever ( I74I-I742) in New YorkCity, of which he wrote an account in Hosack and Francis' Register, vol. i. He loved botany, too, and from Coldenham came his Plantae Coldenghamiae in Provincia Noveboracensi Americes sponte crescentes, quas ad methodum Cl.Linnaei Sexualem, anno I742, observavit Cadwalader Colden. Thacher says the intimacy with Linnaeus came about through a paper Colden wrote on The Virtues of the Great Water Dock.

Linnaeus, writing to Dr. James Lind concerning oedematous swellings on scorbutics says:

"Nor has any cure been found for this state of the disease, except recently in the root of the Water Dock, called Herba Britannica (Rumex aquaticus), which I have introduced on the recommendation of your countryman Colden, who was taught its use by the country people of New York."

When Colden became acquainted with Linnaeus' System, he became even more zealously botanical. He introduced it into America a few months after its publication in Europe and sent Linnaeus his description of some four hundred American plants, which was published in his

${ }^{2}$ Correspondence of Linnaeus, vol. ii, 476 . 
Acta Societatis Regiae Scientiarum Upsaliensis, I 743 .

Linnaeus, in recognition of his services, called a new genus of plants Coldenia, though a prettier version had it that he named it after the doctor's daughter, Jane. "Not only," says Dr. Garden, writing to Ellis, in 1755 , " is the doctor himself a great botanist, but his lovely daughter is greatly master of the Linnaean method and cultivates it with great assiduity." Ellis, in a letter to Linnaeus ( $\left.175^{8}\right)$, suggests that as Miss Colden has drawn and described 400 plants in his (Linnaeus') method, he should call the Helleborus trifolius, Coldenella, and: "You have plainly shewed me that the Fibraurea of Miss Colden is already described. I shall let her know what civil things you say of her. Her Christian name is Jane."

Colden's largest work was his History of the Five Indian Nations of Canada, 1727. The Cause of Gravitation, once an all-absorbing subject with him, resulted in his writing on it, and this paper, much enlarged, was re-published in I75 I as The Principles of Action in Matter. He wrote also an Essay on the Cause and Remedy of the Yellow Fever, so fatal at New York in 1743 and $A$ Treatise on Electricity. His friend-

${ }^{2}$ Correspondence of Linnaeus, vol. ii, p. 343.

${ }^{3}$ Correspondence of Linnaeus, vol. i, pp. 95, 98. 
42 SOME AMERICAN MEDICAL BOTANISTS

ship with Franklin lent keener interest to the electricity, as they corresponded regularly on this subject. Franklin, in describing the American Philosophical Society to a friend, mentions Colden as its originator.

He left many unpublished papers on meteorology, on vital movement, the properties of light, the intelligence of animals and the admixture of metals. Colden's son became a distinguished mathematician and natural philosopher, and his grandson a senator to the State of New York. Of the learned Miss Jane I find no further details.

Writing to him on June 26, 1743, Bartram says:

"Friend Colden:

"I have lately received order to travel to gather the seeds of the Balm of Gilead and other species of evergreens. The Duke of Norfolk hath subscribed twenty guineas, the Duke of Richmond and two other gentlemen fifteen more. .... I am now providing for a journey up Susquehanna with our interpreter, in order to introduce a peaceable understanding between the Virginians and the Five Nations."

But the Indians hindered many a botanical journey, for Colden, on the 27 th of January, 1747 . tells Bartram:

"Memorials of Bartram and Marshall. Darlington. 
"All my botanical pleasures have been stopped this summer, while I was at Albany. We durst not go without the fortification without a guard for fear of having our scalps taken; and while I was at New York I was perpetually in company or upon business, so that I shall be a very dull correspondent. . . . . I expected to have heard from Gronovius by a ship expected from Amsterdam and by which I wrote to him; but I do not hear that she is arrived. I sowed some of the seed of the Arbor vitae, but it failed as yours did. Perhaps they may germinate next year."

Amer. Med. and Philos. Reg., vol. i.

Dict. of National Biog. Stephens.

Memorials of Bartram and Marshall. W. Darlington.

Smith's Corres. of Linnaeus.

Drake's Dict. of Amer. Biog.

Bancroft's Hist. of the United States of America.

Nichol's Literary Anecdotes. 


\section{JOHN CLAYTON \\ I $693-1773$}

\section{Claytonia Virginica-GRONOVIUS}

John Clayton, the botanist, must not be confounded with a naturalist of the same name and period, though more than likely he is a connection. The latter was rector of Crofton, Wakefield, in Yorkshire, England, whence nearly all the Claytons came, but was something more than a theologian, as, after journeying to America, he communicated the result of his natural history gleanings to the Royal Society of London in two papers entitled An Account of Several Observables in Virginia and in his Voyage hither, by John Clayton, and Some More Observables (Phil. Trans., I688). D. Waterson found these papers in a small second-hand bookstore in London and secured them for I 2 cents. Later I noted that Quaritch was asking \$I4! Crofton Church, where John the divine officiated, was built in I 437-I467, and is still standing. My friend, Dr. Sykes, who lives near it, had a photograph taken for me.

The John Clayton after whom our beautiful little modest Claytonia ("Spring Beauty") was 


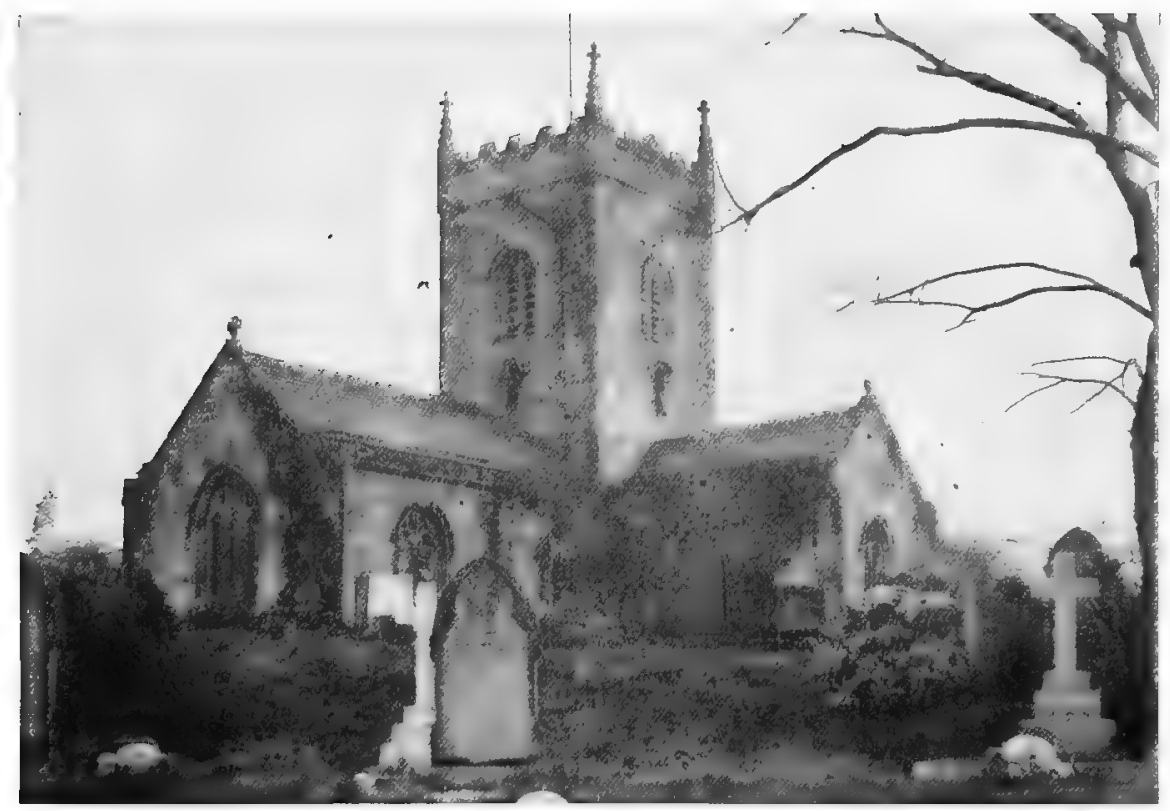

CROFTON CHURCH, YORKSHIRE, ENGLAND 

named entered this life in Fulham, London. Barton (Med. and Phys. Jour., vol. ii) says he came to Virginia with his father when the latter was Attorney-General of Virginia. Other biographers ${ }^{1}$ state that he joined his father in 1705 .

Where he studied or whether he ever took his M. D. degree seems not ascertainable, though Thacher calls him "an eminent botanist and physician " and Leslie Stephen says "he studied medicine." He seemingly did not begin as a doctor, but was put by his father in the office of Peter Beverley, Prothonotary for Gloucester County, Virginia. When Beverley died, Clayton succeeded him and held the post for 5 I years. Apparently this work gave him leisure to make excursions over the country, to continue his chemistry, and do a little doctoring. Most scientists of that time sent the results of their scientific gleanings over to the Royal Society in London; so, like the Observables of the other John Clayton, our botanist in 1739 sent his Experiments concerning the Spirit of Coals, while his papers on the flora of Virginia were published in the Philosophical Transactions, London, vols. xvii, xviii and xli.

These writings led him into correspondence with European naturalists, especially the Dutchmen, John F. and Laurence Gronovius, who pub-

${ }^{2}$ Biographical Dict. Rose.

Dict. Nat. Biog. Stephens. 
46 SOME AMERICAN MEDICAL BOTANISTS

lished their Flora Virginica exhibens Plantas quas in Virginia Clayton collegit (Leyden, I739 and $\mathrm{I}_{745}$ ). These parts were reissued after Clayton's death in 1782. Turning over the pages of the Correspondence of Linnaeus, I find some letters which interestingly refer to this. In his letters to Haller, 1737 and 1738 , Linnaeus remarks that "Gronovius will, doubtless, soon publish the plants sent by Clayton from Virginia, unless he considers too long about the matter," and:

"I have at length received from London a specimen of that American Polygala for which a certain empyric received a thousand pounds sterling from the English American Society; this man having found its root a specific for I know not what disorder.

"The plant has many characters in common with the Penoea of Plumier. Gronovius no doubt will describe it amongst his Virginian plants. I wish he had not so long hesitated to publish his book. He is too timid. You would scarcely believe how many of the vegetable productions of Virginia are the same as our European ones. There are Alps in the country of New York, for the snow remains all summer long on the mountains there. I am now giving instructions to a medical student here, who is a native of that country" (Adam Kuhn?) "and 
will return thither in the course of a year, that he may visit those mountains and let me know whether the same plants are found there as in Europe."

But Gronovius of Leyden, ${ }^{2}$ writing to Richard Richardson,' an English botanist, in 1738 , says:

"I now send you all the rest of Linnaeus' works, in which you will find great learning and many curious remarks. Most of your triflers in Botany dislike his method, and particularly his Critica, because they do not understand him. ... I assure you, Sir, it was by his principles alone that I could reduce several of your Virginian plants to their proper Genus, as you will see in the Flora Virginica. This work will go to press as soon as the Hortus Cliffortianus is published, which I expect every day."

Laurence Gronovius gave the name of Claytonia to a genus of perennial plants of which the Claytoniu Virginica is popularly known as the "Spring Beauty," on account of its early appearance.

I do not know whether Clayton hoped, like old Dr. Garden, that he could roam over celestial fields in search of specimens, but he departed this life the $15^{\text {th }}$ of December, I773, happy in the thought that two volumes of botany notes would

${ }^{2}$ John F. Gronovius, M. D., I690-1762.

${ }^{8}$ Richard Richardson, I663-I74I (Richardsonia, Linn.) 
be published and his Hortus Siccus, in folio, with full marginal notes for the printer and engraver, would benefit the Virginians. Unfortunately, an incendiary set fire to the Town Clerk's office where they were safely stowed away, and all were burnt.

When seventy-seven, Clayton made a botanical tour of Orange County, then largely a wilderness, and visited nearly all the settled parts of Virginia. He was wont to declare that no botanist could be an atheist, seeing, as he did, infinite wisdom in the structure of the smallest plant. From the scanty records left, it is evident that John Clayton was a godly member of the Church of England and a most useful citizen.

Contributions to the Annals of Medical Progress. Toner.

American Medical Biography. Thacher.

Dict. of National Biography. Stephens.

Correspondence of Linnaeus.

Memorials of Bartram and Marshall. Darlington. 


\section{JOHN BARTRAM \\ I699- I 777}

\section{Lantana Bartramii-BALDWIN}

Let John Bartram tell in his own words how he was first led to study the science which made him in after years a pioneer botanist in America. "One day," he says, "I was very busy in holding my plough (for thou seest that $I$ am but a ploughman), and being weary I ran under a tree to repose myself. I cast my eyes on a daisy; I plucked it mechanically and viewed it with more curiosity than common country farmers are wont to do, and observed therein very many distinct parts, some perpendicular, some horizontal. 'What a shame,' said my mind, 'that thee shouldst have employed thy mind so many years in tilling the earth and destroying so many flowers and plants without being acquainted with their structures and their uses.' . . . . I thought about it continually, at supper, in bed, and wherever I went, . . . . on the fourth day I hired a man to plough for me and went to Philadelphia. Though I knew not what book to call for, I ingeniously told the bookseller my errand, who provided me with such as he thought best, and a 


\section{SOME AMERICAN MEDICAL BOTANISTS}

Latin grammar. Next I applied to a neighboring schoolmaster, who in three months taught me Latin enough to understand Linnaeus, which I purchased afterwards. Then I began to botanize all over my farm. In a little time I became acquainted with every vegetable that grew in the neighborhood. . . . . By steady application of several years I acquired a pretty general knowledge of every plant and tree to be found on our continent. In process of time I was applied to from the old countries, whither I every year send many collections."

So wrote America's earliest botanist and the founder of her first botanical garden.

He was born on the 23d of March, I699, in Derby, Delaware County, Pennsylvania, son of William and Elizabeth Hunt Bartram, descendants of Richard Bartram of Derby, England, whose son, grandfather of our botanist, came over to Pennsylvania in 1682 .

The inheritance, from an uncle, of a farm in Derby placed him a little above those petty cares which fret the heart of a scientist, and as he had an early inclination to medicine he acquired so much knowledge as to be useful to sick neighbors who were unable to get to Philadelphia. Probably most of his remedies were herbal, from plants gathered by himself, but he was able to prepare the notes and appendix to the American 


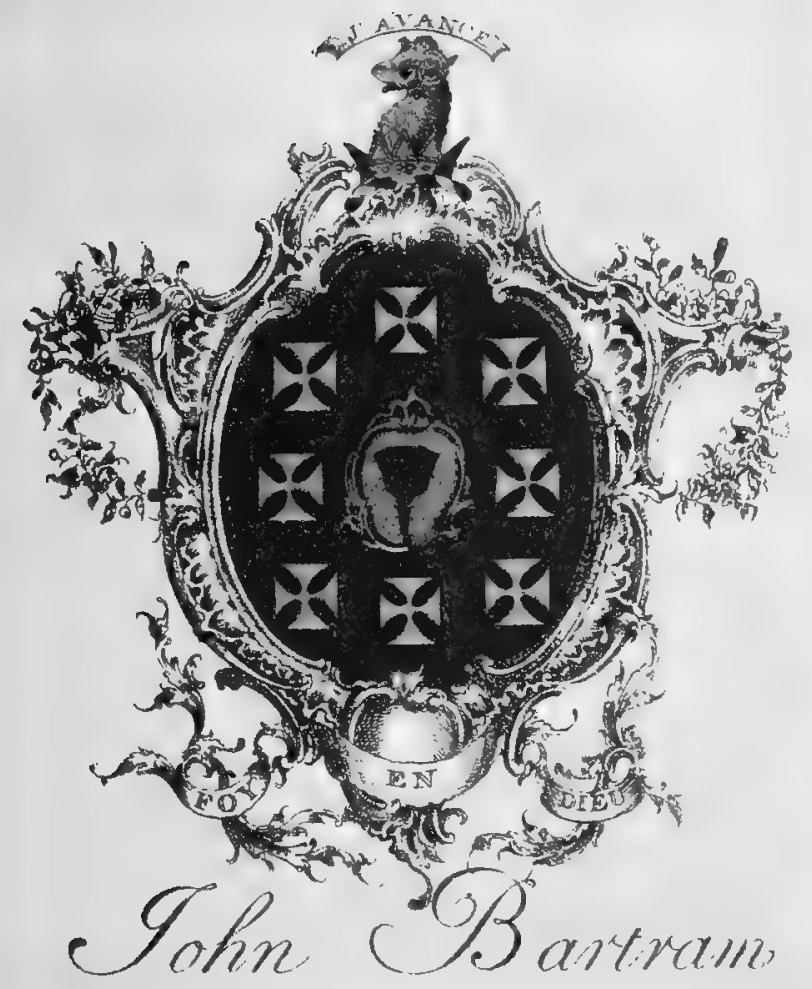

(By permission of Professor Harshberger) 

edition of Short's Medicina Britannica, published by Benjamin Franklin in I75 I.

Haller, in his Bibliotheca Anatomica, speaks of him as a physician, and certainly he devoted much of his time to physic and surgery, obtaining some celebrity in the latter. He bought for his botanical garden a piece of land about three miles from Philadelphia on the Schuylkill, and built a house there with his own hands. He employed much of his time in specimen hunting and natural history research, no dangers deterring him. A modern explorer with an air bed, camp furniture, collapsible tent (and hopes) is a pigmy, contrasted with this John setting out when seventy years old from Philadelphia to explore in Florida. This was before the days of Governmental Commissions, and Bartram paid his own expenses. When he had gathered a large natural history collection, one of his friends-Joseph Breintnall, a Philadelphia merchant-undertook to convey some to the botanist, Peter Collinson, ${ }^{2}$ in London; and it was chiefly through Collinson that Bartram found correspondents throughout Europe and became a member of the Royal Society in London and in Stockholm. Collinson says in one of his letters:

${ }^{1}$ Peter Collinson, r693-1768 (Collinsonia Canadensis. Linnaeus). 
52 SOME AMERICAN MEDICAL BOTANISTS

"My good Friend, John Bartram:

"I am very sensible of the great pains and many toilsome steps to collect so many rare plants scattered at a distance. I shall not soon forget it; but, in some measure to shew my gratitude, though not in proportion to thy trouble, I have sent thee a small token : a calico gown for thy wife and some odd little things that may be of use amongst the children and family. They come in a box of books to my worthy friend, Joseph Breintnall, with another parcel of waste paper which will serve to wrap up seeds, etc. ... Thou canst not think how well the little case of plants came, being put under the captain's bed, and saw not the light till I went for it. ... The warmth of the ship and want of air had occasioned the Skunk-weed to put forth two fine blossoms, very beautiful, but it is of the Arum genus. . . . As I hope to make a present of a part of the seeds (sent) to a very curious person, Lord Petre, I hope to procure thee some present for thy trouble of collecting.

"I am thy very sincere friend, P. Collinson."

"London, January 24, I735."

Any one desirous of some pleasant reading about this genial and learned Bartram should take an hour or two with The Memorials of John Bartram and Humphry Marshall, by Dr. William Darlington, Philadelphia, I 849. 
în.

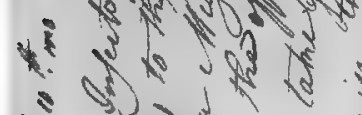

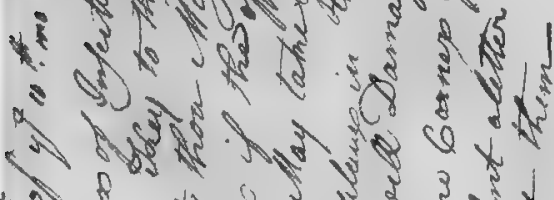

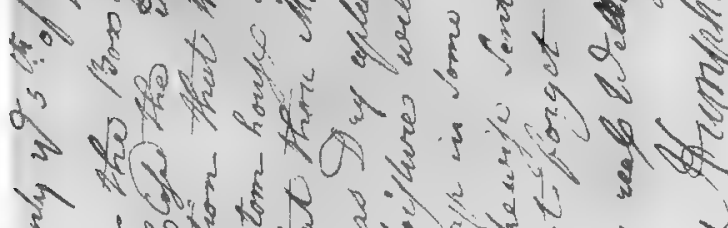

- 104010

d)

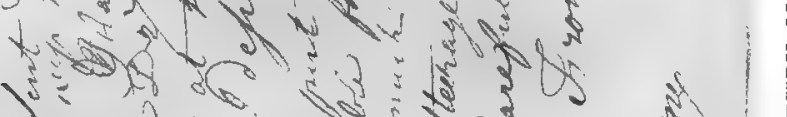

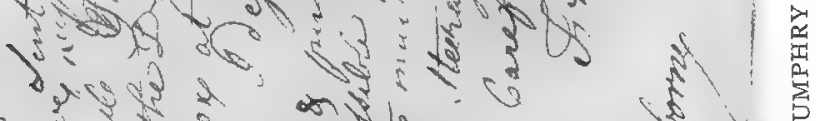

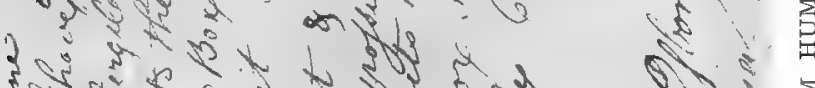

हुका

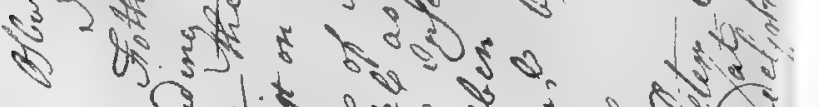

is Q 

In January, I723, Bartram married Mary, daughter of Richard Maris, of Chester, and had two sons, Richard and Isaac. Two years after her death in 1727 he married Ann Mendenhall, and had nine children: James, Moses, Elizabeth, Mary, William and Elizabeth (twins), Ann, John, and Benjamin.

It was William Baldwin who named a plant after Bartram. A letter from him, dated 1817 , in the Reliquiae Baldwinianae, says:

"As our venerable botanical friend, Bartram, will perhaps be somewhat disappointed in not seeing or hearing from me, I should be glad if you call upon him the first opportunity, and make an apology for me. It is my intention to do him all possible justice in my notices of Florida plants. The Lantana which he discovered I have called L. Bartramii-foliis ovatis, obtusis, crenatis; caule herbaceo, angulato, aculeato, piloso, ramoso; floribus capitato-umbellatis, foliosis. This is a beautiful plant, attaining to the height of six feet-and abounds along the coast of Florida. The account given of it by Bartram is very correct. It may come very near the $L$. aculeata of South America."

${ }^{2}$ The Linnaean genus Bartramia was unquestionably named after John Bartram, although he thought it superfluous to say so. The same is true of the well-known genus Bartramia of Hedwig. Neither name is now tenable under modern rules of nomenclature. (J. H. Barnhart.) 


\section{SOME AMERICAN MEDICAL BOTANISTS}

John Hedwig,' the celebrated muscologist, also named a genus of mosses Bartramia, while Lindley gives this and another, on which it was proposed to found a new genus; but the latter was ultimately referred to the Triumfetta of Plumier and Linnaeus." (Darlington.)

In Paxton's Botanical Dictionary," I 840, he describes Hedwig's Bartramia as "an elegant genus of mosses, remarkable for their green leaves and spherical capsules. The genus approaches nearly to Bryum, but differs in almost every species having spherical capsules, and the sixteen broad segments of the inner peristome, instead of being entire, or only perforated, are cleft like the teeth of a Dicranum."

$\mathrm{He}$ employed much of his time travelling through the different provinces of North America subject to England. "Neither dangers nor difficulties impeded or confined his researches after objects in natural history. The summits of our highest mountains were ascended and explored by him. The lakes Ontario, Iroquois and George.... the shores and sources of the great rivers were visited by him at an early period -when it was truly a perilous undertaking to travel in the territories, or even on the frontiers of the Aborigines."

"John Hedwig, I730-ז799.

"Joseph G. Gaetner, M. D., I732-I791.

- Joseph Paxton, r8or-r865. 
When Bartram was on his travels he stayed some days with Dr. Alexander Garden in Charleston, and it is rather amusing to read a letter from Garden to John Ellis (in 1765) :

"My dear friend, et mihi Magnus Apollo:

"First of all let me inform you that I have had Mr. Bartram for my guest for these nine days past. He went this day for Cape Fear, from whence he returns to me in about three weeks, and then he proposes to set out for East Florida. I have had many conversations with him, and have endeavored to give him all the light and assistance I could into the nature of the hot southern climates, and their productions. I have been several times into the country and places adjacent to town with him, and have told him the classes, genera, and species of all the plants that occurred, which I knew. I did this in order to facilitate his enquiries, as I find he knows nothing of the generic character of plants, and can neither class them nor describe them; but I see that, from great natural strength of mind and long practice, he has much acquaintance with the specific characters; though this knowledge is rude, inaccurate, indistinct and confused, seldom determining well between species and varieties. ....

"This I hope will render his enquiries into the Florida plants more certain and accurate; 


\section{SOME AMERICAN MEDICAL BOTANISTS}

and I shall rejoice if it is of the least service to him. He tells me that he is appointed King's Botanist in America. Is it really so? Surely John is a worthy man; but yet to give the title of King's Botanist to a man who can scarcely spell, much less make out the characters of any one genus of plants, appears rather hyperbolical. Pray how is this matter? Is he not rather appointed or sent, and paid, for searching out the plants of East and West Florida, and for that service only to have a reward and his expenses? Surely our King is a great King! The very idea of ordering such a search is noble, grand, royal. It may be attended with much use to mankind, much honour to the Royal Patron; and it will be a further illustration of the power, wisdom, and goodness of our great Heavenly Father."

These remarks concerning his guest as King's Botanist advert to Bartram's appointment and reception of an order to discover the source of the great river St. Johns. Four hundred miles he travelled, and in the course of this journey made an accurate survey of the river, its lakes and branches, the soil, animals and climate, which was published in London.

There seems to have been a little rivalry between Bartram and Garden, though, referring 
again to the correspondence of Linnaeus, Garden says to Ellis ( 1765 ), with a generous enthusiasm: "You tell me you are surprised that I overlooked a new species of the live oak which John Bartram found near Charleston. Let me assure you that John Bartram received from me these very specimens, some of the Phillyrea and many others, from my Hortus Siccus, of which he has, it seems, made a different use from what I apprehended. Yet, after all, he is an excellent man and I forgive him, because it is a matter of little moment who declares the glories of God, provided they are not passed over in silence."

The two always seemed good friends and freely exchanged specimens. Bartram grumbles a little at some of his European correspondents "who write to me as freely for the Carolina plants as if they thought I could get them as easily as they do the plants in the European gardens; that is, to walk at their leisure along the alleys and dig what they please out of the beds without the danger of life or limb."

Still, he had compensations at home, for he says ( I 762 ): "I have received a lovely parcel this Spring from Mrs. Logan,' my 'fascinated widow.' I have also fascinated two men's wives, although one I never saw, that is, Mrs. Lamboll, who hath sent me two noble cargoes."

- A great florist, who married at fifteen and wrote a Treatise on Gardening when seventy years old. 


\section{SOME AMERICAN MEDICAL BOTANISTS}

His personal character in all records is shown to be that of a genial philanthropist with a capability for righteous wrath on occasion. He seems to have anticipated Tolstoy in the "simple life," with his slaves emancipated before the war sitting at the lower end of the dining table, and the fare plentiful but plain. He loved his Bible and read it to his boys and girls. Over the windows of his study was carved:

“'Tis God alone, Almighty Lord,

The holy One by me adored.

"John Bartram, 1770."

Glimpses are caught of his home life in unexpected places. Dusty volumes piled around and wearily read often light up after some little search with glowing accounts of the man I seek. Here is one-Letters from An American Farmer written for the Information of a Friend in England (1782). Hector St. John de Crêvecoeur, the author, was Consul-General to the United States and, being interested in agriculture and natural science, went to call on Bartram, and keenly enjoyed the host and his homestead.

"We entered into a large hall where there was a long table full of victuals : at the lowest part sat his negroes; his hired men were next, and at the head the venerable father and his wife presided. ... Soon after dinner, I heard, as I thought, a distant concert of instruments. . . . Anxious, 
I followed the sound, and, by ascending the staircase, found it was the effect of the wind through the strings of an Aeolian harp..... After dinner we quaffed an honest bottle of Madeira wine ... . and then returned to his study."

Although he lived to be nearly 80 , he had never coveted an old age, fearing he would become useless to society. "I want to die" were his last words, when a short illness bore him, still keenwitted, to the grave.

Memorials of John Bartram and Humphry Marshall. William Darlington. Philadelphia, I849.

Medicina Britannica.

Biog. by Thomas Short.

Correspondence of Linnaeus.

The Botanists of Philadelphia. J. W. Harshberger. 


\section{ALEXANDER GARDEN \\ I728-г 792}

\section{Gardenia jasminoides-ELLIS}

Alexander Garden, of Charleston, South Carolina, was a valued friend of Marshall, Sr., and such a diligent and graceful correspondent with other eminent botanists of his day that much which is interesting concerning his life can be culled from his letters by those who will con them with the affectionate attention they deserve at the hands of an interested posterity.

His father, also named Alexander, who was a clergyman at Birse, near Aberdeen, Scotland, went out in I7I 9 to Charleston and became rector of St. Philip's Church there. He seems to have been a good deal of an autocrat, for he lived in the stirring times of religious revivalism and it is related that after promising George Whitefield his support, he denied him the use of St. Philips because Whitefield had become a "field preacher."

Alexander the second was sent home to be educated, and studied in Edinburgh under the celebrated Dr. Gregory and Alston the botanist. He graduated as an M. D. in Edinburgh and re- 


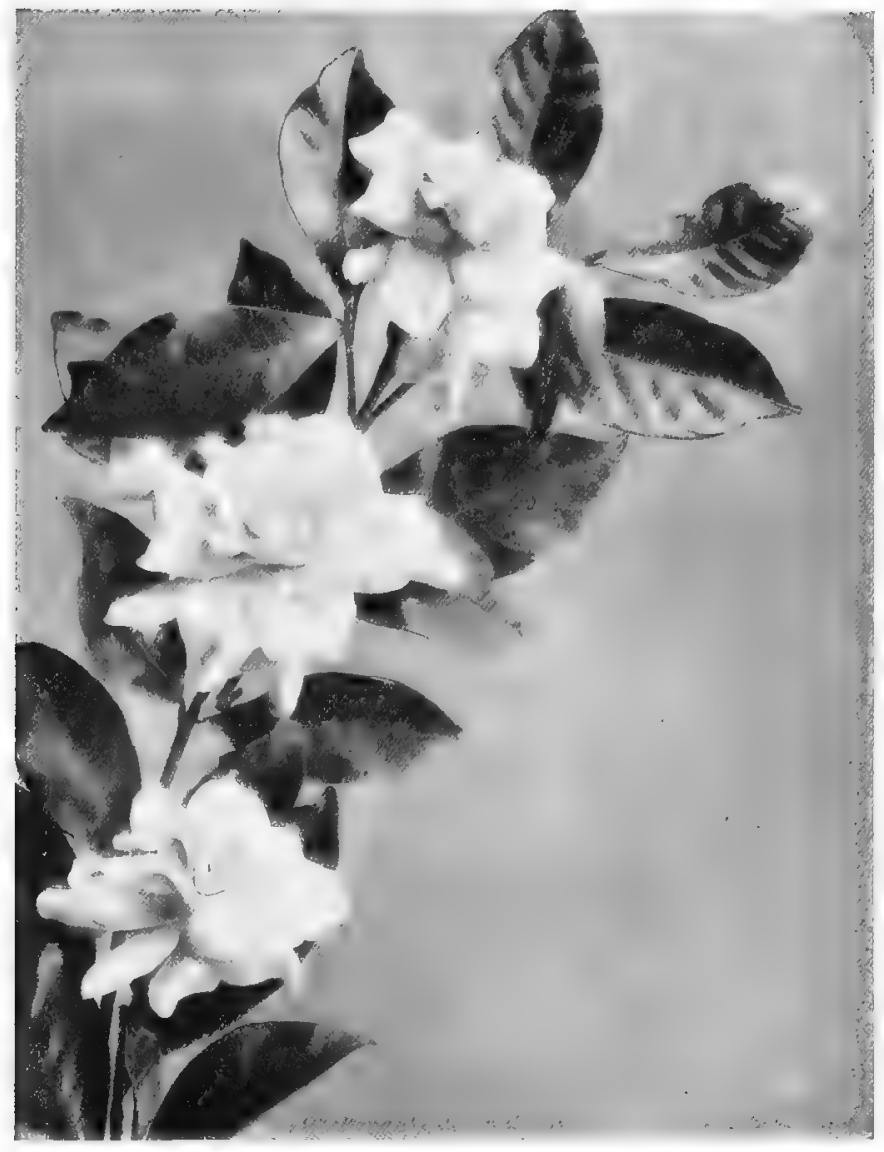

G.IRDENIA JASMINOIDES

(From the J. Horace McFarland Nurseries) 

turned to Charleston in 1752 ; but went for a while before this as professor at King's (afterwards Columbia) College, New York. Returning to Charleston, he began a successful practice. Glimpses of his life at this time are given in his letters, one of which is to John Bartram, the botanist: "Think that I am here, confined to the sandy streets of Charleston, where the ox, where the ass, and where man, as stupid as either, fill up the vacant space, while you range the green fields of Florida."

Not one in a thousand knows after whom the genus Gardenia was named, so I quote a letter from Linnaeus to John Ellis, the botanist ( 760$)$, in which he says:

"I had given the name of Gardenia to an entirely new and very singular genus, the Catti marus of Rumphius, $A m b o i n$, v. z. 177, t. II 3 , in order so far to conform to your wishes. But as you still persist in your decision, that the Jasmine so often mentioned between us should be called Gardenia, I will comply, though I cannot but foresee that this measure will be exposed to much censure. I find it impossible to deny you anything. All that I beg of you, my dear friend, is, that you would publish the genus and its character in some loose sheet, or some periodical

${ }^{1}$ Some biographers say he declined the invitation to King's College.

${ }^{2}$ Correspondence of Linnaeus, vol. i, p. 135. 


\section{SOME AMERICAN MEDICAL BOTANISTS}

work, or Transactions; in which case I promise to adopt the name. I wish to learn from you what Dr. Garden has written in Botany, or what he had discovered that I may make mention of it." Garden gives evidence of his botanic tastes in a letter to Ellis himself:

"You will no doubt readily think that it is odd in me, who live so far from the learned world, to have such an avaricious desire after new correspondents. I own it is really odd; but I cannot help it, and I think that nothing is a greater spur to enquiries and further improvement, than some demands from literary correspondents. I know that every letter which I receive not only revives the little botanic spark in my breast, but even increases its quantity and flaming force. Some such thing is absolutely necessary to one, living under our broiling sun, else ce feu, cette divine flame, as Perrault calls it, would be evaporated in a few years, and we should rest satisfied before we had half discharged our duty so our fellow creatures, which obliges us, as members of the great society, to contribute our mite towards proper knowledge of the works of our common Father."

The study of zoölogy, especially fishes and reptiles, filled up the leisure left from a large practice and botanizing; and he kept up an active correspondence also with Linnaeus, to whom he sent large collections of fishes so well prepared 


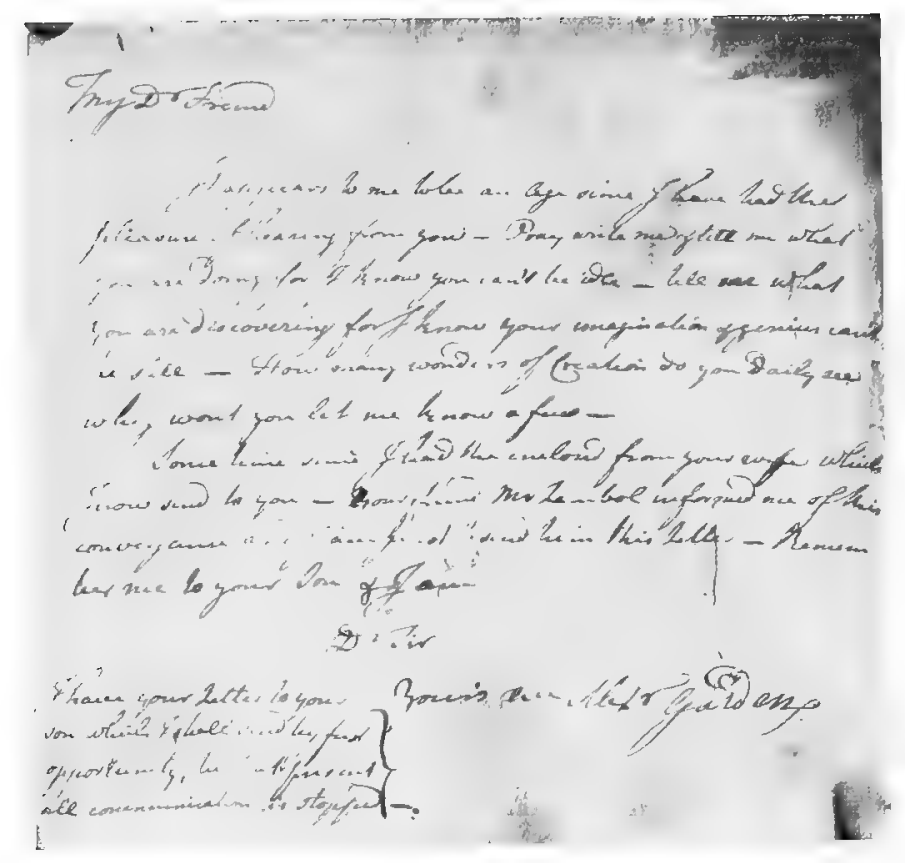

LETTER FROM DR. ILEXINDER GARDEN IN THE POSSESSION OF THE AUTHOR 
that when Prof. G. Brown Goode, of Washington, D. C., saw them in 1883 , he found "nearly every specimen referted to by him (Garden) in his letters in excellent condition, though few collected by others were identifiable."

Garden discovered the Amphiuma means (Congo snake), and was instrumental in sending the first electrical eels to Europe. He tells Ellis (1775) that, owing to a very severe fever, he had not been able to examine them thoroughly, but their structure seemed so uncommon, he had written a paper which might be read by Ellis before the Royal Society (An Account of the Gymnotus Electricus, I775).

"I desired him" (the owner of the eels) "if they arrived safe, immediately to go to you, but, lest they should die by the way, I desired him to put them into a small Kegg of rum. .... I wish to hear both of the fate of my letter and of these fish. I have had so very disordered a state of health that I have not been able to do anything in the way of procuring materials for fresh observations in Natural History."

$\mathrm{He}$ also sent-to Linnaeus-in 1770 , a description of the vermifuge Spigelia Marylandica, or Indian Pink Root, telling him the account of it would appear in the Essays and Observations of the Edinburgh Philosophical Society and promising to find out whether the Chigo ("jigger") 
64 SOME AMERICAN MEDICAL BOTANISTS

flea of Catesby can be found as far north as Carolina.

It was about this time ( I 77 I) that an interesting lad who had been educated in Scotland came to him as pupil. This was William Charles Wells, afterwards to become known for his papers on The Formation of Dew and An Essay upon Single Vision with Two Eyes. Wells had two trials in early life: one, an arbitrary father; the other, our friend Garden. Wells' father, fearing the lad should become tainted with disloyalty after the Peace of $I_{7} 6_{3}$, compelled him to wear Highland dress, hoping to make him remember he was a Scotsman. Wells says bitterly, speaking of his boy companions, "The persecution I hence suffered produced this effect completely." He tells also that "Dr. Garden had been accustomed to apprentices of a very different character [from himself] and frequently suspected me of falsehood and once attempted to strike me with his hand. From this time I became in my conduct to him reserved and indignant . . . and betook myself seriously to study."

The somewhat choleric Garden and the "reserved and indignant" Wells must have made the Charleston home an uncomfortable one during the three years' apprenticeship!

Thacher, who loves to disguise weaknesses in wordy dressing, and admits only that a doctor 
"was addicted to the too frequent imbibition of spirituous liquor," but never that he was drunk, says that Garden was "particularly fond of refined female society and to it devoted a considerable portion of his time, but enough was reserved for mental improvement!"

He married Elizabeth Peronneau, and writes to Ellis: "A love affair prevented me from attending much to my studies or collections," and "I hurry away to meet the parson and my dear girl, so must bid you adieu." He had a son and two daughters, but his family is now extinct.

Eager to extend his knowledge, in I755 he accompanied James Glen, Governor of South Carolina, when the latter penetrated the Indian country and formed a treaty with the Cherokees. About 1772 Garden was made a fellow of the Royal Society of London, and eventually its vicepresident.

A somewhat pathetic interest is attached to a little granddaughter, named "Gardenia." Her father, Alexander, Garden's only son, joined Lee's legion against the British and was never forgiven; nor was the little girl, his granddaughter with the flower name, ever received into the house. This son he sent to England to be educated under Mr. William Rose, his own schoolmaster, and introduces him to Ellis: ${ }^{3}$

${ }^{3}$ Correspondence of Linnaeus, vol. i, p. 603. 


\section{SOME AMERICAN MEDICAL BOTANISTS}

"I have now, my dear Sir, to beg leave to introduce to you the bearer of this, my only son. He has been in England four or five years, but I could not think of troubling you with his visits while he was too young to profit from your conversation. He will now soon leave London to repair to a University; but as he will now and then visit London during the vacation times, I could wish that he had at such times your leave to pay his respects to you, to enquire after your health, and be permitted to see and converse with his father's most esteemed and valued friend.

"I am yet entirely unacquainted with any particular penchant which he may have, or to what profession his genius may incline him. But I think I could wish him to have pleasure in looking at, considering, and admiring the works of his Creator, in the various forms in which they appear to us. This would never interfere with any profession, and it would be a source of benefit to himself. For this reason I should be happy to have him acquainted with, and introduced to, the curious gardens about London, if it should happen at any time to fall in your way to take him with you in any of your walks to Mr. Gordon's or any other curious gardens. I should exteem it a great favour done me."

The lad went to Westminster School and Glasgow University, and after the war he received a 



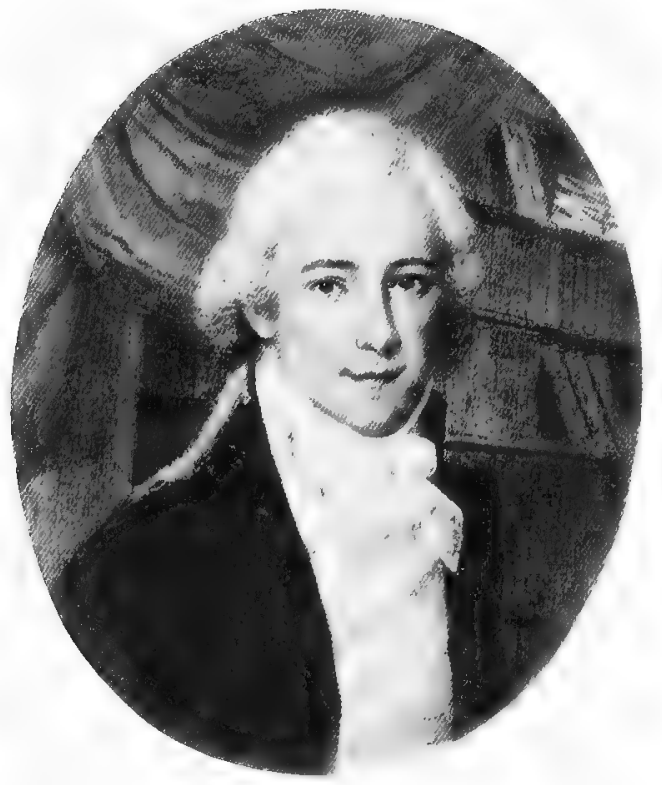

ALASTAR, THE LAST OF THE GARDENS

(From a miniature belonging to Mrs. Henry S. Holmes) 
grant of his father's confiscated estates and married Mary Ann Gibbes. A copy of his Anecdotes of the Revolutionary $W$ ar, 1822 , is in the British Museum, and an original miniature, kindly lent me by Mrs. Henry S. Holmes, of Charleston, shows his son Alastar, the last of the Gardens.

Tuberculosis, hitherto successfully fought, began to tell on Garden's health in 1783 , although it was hoped, in vain, that "revisiting the haunts of his youth [England and Scotland] and the pleasing recollections of juvenile scenes would have salutary influence in arresting the disease." The good time every learned man tried to give him as guest, during the progress homeward and while travelling in Europe, exhausted his strength. He stayed, with wife and two daughters, in Cecil Street, off the Strand, London, a part of the city up which to-day, as then, creep fog and mist from the river-a bad exchange for Carolina sunshine. Here, patiently realizing that nothing could be done, he put on paper all he could of his Carolina work, enjoyed the men who flocked to him, and got ready for his last long journey. He died peacefully in London, in I792, perhaps realizing in some measure that which he had playfully written of in a letter to Linnaeus, dated 176 I: 
"Remember me in a particular manner to Dr. Solander. How happy I should be in having an hour or two's tête-a-tête with you both! If seas and mountains can keep us asunder here, yet surely the Father of Wisdom and Science will take away that veil and these obstacles when this curtain of mortality drops; and probably I may find myself on the skirts of a meadow, where Linnaeus is explaining the wonders of a new world to legions of white candid spirits, glorifying their Maker for the amazing enlargement of their mental faculties. What think you of this time, my dear friend? Shall we have a hearty shake of the hand if such practises be fashionable or in the mode? Believe me, I long to see more of my God, and to know many of my friends that I am afraid I cannot meet elsewhere," "

Memorials of Bartram and Marshall. W. Darlington, 1849 .

American Medical Biog. Thacher.

Memoir of Dr. W. C. Wells.

The beginnings of Natural history in America. G. Brown Goode, 1886.

Ramsay's Hist. of S. Carolina, vol. ii.

Smith's Correspondence of Linnaeus.

George Whitefield. J. P. Gledstone.

Information from (Mrs.) Harriott Horry Ravenel, of Charleston, S. Carolina.

"Correspondence of Linnaeus, vol. i, p. $5 \mathrm{Ir}$. 


\section{ADAM KUHN}

$$
\text { I 74I-I } 817
$$

\section{Kuhnia Eupatorioides-LINNAEUS}

Meanwhile, botanists were increasing in America, especially in Pennsylvania, which state gave us the pompous, methodical, learned Adam Kuhn. It was of him that the great Linnaeus sat down on February 24, 1763 , to write to Adam Kuhn, senior, living in Philadelphia, in fine Latin commending his pupil, Adam junior:

" He is unwearied in his studies and daily and faithfully studies materia medica with me. He has learnt the sympathetic history of diseases in an accurate and solid manner. In natural history and botany he has made remarkable success. He has studied anatomy and physiology with other professors."

Kuhn was born at Germantown, near Philadelphia, November I7, I74I. His grandfather, John Christopher Kuhn, and his father, Dr. Adam Simon Kuhn, came from Heilbronn, Swabia, to Philadelphia in September, I733. Adam first studied medicine with his father, then sailed for Europe, in 1761 , and arrived at Upsala by way of London. 
There is a little glimpse of his life in Upsala in the diary of Professor Fabricius, then fellowpupil with Kuhn, who writes:

"For two whole years [from i762 till 1764 ] have I been so fortunate as to enjoy his [ Linnaeus'] instruction, his guidance and his confidential friendship. Not a day elapsed on which I did not see him, on which I was not either present at his lectures, or, as it frequently happened, spent several hours with him in familiar conversation. In summer, we followed him into the country. We were three, Kuhn, Zoega and $I$, all foreigners. In winter we lived directly facing his house, and he came to us almost every day in his short red robe-de-chambre with a green fur cap on his head and a pipe in his hand. He came for half an hour, but stopped a whole one and many times two. His conversation on these occasions was extremely sprightly and pleasant. It either consisted in anecdotes relative to the learned in his profession, with whom he got acquainted in foreign countries, or in clearing up our doubts, or giving us other kinds of instruction. He used to laugh then most heartily, and displayed a serenity and an openness of countenance which proved how much his soul was susceptible of amity and good-fellowship."

\footnotetext{
'Stoever's Life of Linnaeus.
} 


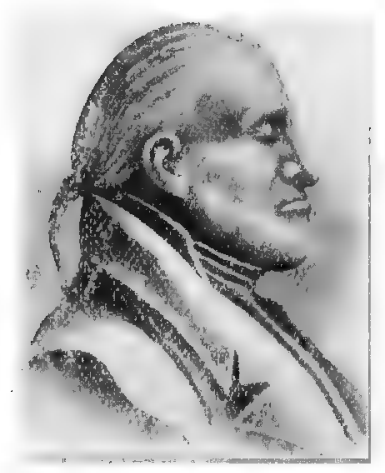

ADAM KUHN 

Kuhn arrived in London in r764 and studied there a while. In 1767 he was in Edinburgh, where he took his M. D. at Edinburgh University the same year. His thesis De Lavatione Frigida, or the use of cold bathing in fevers, was dedicated to his friend Linnaeus.

John Ellis, writing to Linnaeus from London in 1765 , tells him, "Poor Kuhn has been very ill of a pleuritic fever, but is now crawling about "; and in the same year, "Our friend, Adam Kuhn, is now at W. Pitcairn's, a merchant in Edinburgh, Scotland: I do not doubt but he will promote the subject of Natural History there."

Ellis does not seem so much in favor of Kuhn in 1770 , for he says to Linnaeus :

"Dr. Kuhn is one of those American chiefs that despise us Englishmen. I sent him some seeds of the Rheum palmatum by a friend and he had not the decency to thank me; but his German pride will do him no service, for, thank God, we shall now humble those American revolters. He is, to my knowledge, infinitely obliged to you: without your care in cultivating his mind he would have been a mere savage."

After this explosive statement Kuhn figures no more in the Correspondence.

In 1768 , after his return to Philadelphia, he became professor of materia medica and

${ }^{2}$ Correspondence of Linnaeus, vol. i. 
72 SOME AMERICAN MEDICAL BOTANISTS

botany in the College of Philadelphia, being the first professor of this science in America. As a lecturer, in his five or six professorships held, "he was faithful and clear in the description of diseases and in the mode of applying their appropriate remedies, avoiding theoretical discussions." In $\mathrm{I} 774$ he assisted in inoculating a population considerably decimated by small-pox in Philadelphia.

His other appointments included: Physician to the Pennsylvania Hospital ; consulting physician, Philadelphia Dispensary, I786; one of the founders, and in 1808 president, of the College of Physicians of Philadelphia; professor of the theory and practice of medicine, University of Pennsylvania, I789; and on the junction of the two medical schools of the College and University, he was chosen professor of the practice of physic, I792-I797.

Of his writings, with the exception of the thesis mentioned, nothing can be traced save a short letter addressed to Dr. Lettsom on Diseases Succeeding Transplantation of Teeth, and a paper in which he opposed Rush's Treatment of Yellow Fever by publishing his own, over initials, in the General Advertizer of September I I, I 793 (?).

Of Adam Kuhn, Dr. Charles Caldwell, cold, cautious, and sarcastic, says:

${ }^{3}$ Memoirs of the Med. Soc. of London, vol. i. 
"He was by far the most highly and minutely furnished specimen of old-school medical production I have ever beheld. He wore a fashionable curled and powdered wig; his breeches were black, a long skirted buff or white waistcoat, his coat snuff-colored. He carried a gold-headed cane and a gold snuff-box; his knee and shoe buckles of the same metal. His footsteps were sternly and stubbornly regular; he entered the sick-room at a given minute and stayed a given time, and never suffered deviation from his directions. 'Doctor, if the patient should desire toast, water or lemonade may he have it? ' asked the nurse sometimes. He would turn and reply with oracular solemnity, 'I have directed weak sage tea. Good morning madam.' His lectures, not instructive, were mere commonplace. So far from containing an original thought, no portion of them appeared to be the professor's own."

This was pretty strong, yet he adds, without commendation, that Kuhn came to see him (Caldwell) three times a day when he was ill.

Linnaeus, following a pretty fancy, named an American plant Kuhnia (Kuhnia Eupatorioides) after Adam, and when the latter returned to Philadelphia wrote very intimate and graceful letters to him in fine Latin. One has this injunction in it: "I pray and entreat thee send some seeds and plants, among which I ardently desire 


\section{SOME AMERICAN MEDICAL BOTANISTS}

the seeds of the Kuhnia, which perished in our garden."

It would be pleasant to know more of Kuhn, but the short-lengthed, long-adjectived, pompous biographies in old medical journals do not give much. One writer calls him "a discreet young physician, not remarkable for powers of imagination, but his talent for observation profound; a lover of music, abstemious in diet, neat in person."

He did not marry until he was thirty-nine, after which it is gratifying to learn "he had two sons, respectable characters," by his wife Elizabeth, daughter of Isaac Hartman of St. Croix.

When seventy-three he "grieved" his patients by giving up practice, and in June, 1817 , began to feel conscious that life was ending. After a short confinement of three weeks to the house, but suffering no pain, Adam Kuhn passed away on July 5 , in full serenity of mind and heart.

Eclectic Repertory, Philadelphia, 1818. Dr. S. Powell Griffiths.

Stoever's Life of Linnaeus.

Autobiography of Charles Caldwell, Philadelphia, 1855 .

The Botanists of Philadelphia, 1899. Harshberger. 


\section{MOSES MARSHALL}

$$
\text { I758-I } 8 \text { I } 3
$$

\section{Marshallia trinerva-SCHREBER}

The fame of this expert medical botanist has been somewhat eclipsed by that of his uncle Humphry (not a doctor), of whom Darlington left studious and loving record in his Memorials of Bartram and Marshall, but Moses made several long exploring journeys through the wilds of the West and rendered valuable assistance to his uncle in preparing the Arbustum Americanum ( 1785 ).

He was the son of James and Sarah Marshall and the grandson of Abraham Marshall, who came from Gratton, Derbyshire, England, to Delaware, in 1697. West Bradford, Chester County, Pennsylvania, was his birthplace; when he was twenty, Dr. Nicholas Way, of Wilmington, New Castle County, undertook (I776) "to instruct Moses Marshall, son of the said James, in the art of physick, according to the best of his understanding, for the space of two years, which time the said Marshall is to abide with him and his wife," $£ 75$ being the sum paid. Moses did not trouble himself about a medical degree- 
76 SOME AMERICAN MEDICAL BOTANISTS

which was not demanded at that time, nor for a hundred years later, for practice in Pennsylvania-but he had good surgical practice in tending the soldiers wounded in the Battle of Brandywine, September I I, I 777.

As it was customary to attend a course of lectures, he went to hear William Shippen and Rush at a cost to his father, owing to the depreciation of paper currency, of $£_{15}$ o. His diary at this time shows medicine not wholly absorbing, for frequent mention is made of a certain Polly Howell and of Sally Samson, the latter "behaving for three evenings, especially the last, in a most engaging manner." Then followed a year or two of desultory medical work, including inoculations round about London Grove, Pennsylvania, and the keeping of an apothecary's shop "which came to nothing and less." The truth was he had not found his true vocation, which was botanizing. His uncle writes to Franklin in 1785, and Moses himself to Dr. Lettsom in London, suggesting a government-supported exploration of the western states. That he was competent to lead one was known from the fact that he had already made a botanical trip to Pittsburg, the party travelling in wagons. "We have been," he writes to his uncle, "among the pine mountains, where we have seen cucumber trees, rhododendrons, mountain raspberries, and yester- 
day, about Juniata, the broad willow-leaved oak and the red-berried elder." A careful entry was made of everything interesting, and he speaks of intending to bring home specimens of the horsechestnut tree.

In I786 Sir Joseph Banks wrote Humphry Marshall, asking for one hundredweight of fresh ginseng roots. Moses spent twenty days in the Alleghanies getting these, and charged Lettsom $\$$ I.25 a pound, not a high price, considering the perils encountered; and uncle Humphry Marshall lets Sir Joseph know that the ginseng had been obtained at considerable expense, by telling him that his nephew had had to "travel about 200 miles to the westward through a dismal mountainous part of our country, as the ginseng is either dug up for sale, or rooted up by the hogs, so much that it begins to grow scarce in the habitable parts. ... He was likewise obliged to hire a person at a dollar a day to assist him in digging said ginseng, both of them being obliged to camp in the mountains, strike up a fire, and lie by it all night..... If thou thinkest [the price] too much, be pleased to pay what thou thinkest would be a compensation." It is then he asks if Moses could be employed by the Royal Society.

\footnotetext{
${ }^{1}$ When I was a boy, the natives were still digging ginseng roots in the Alleghany mountains of Pennsylvania and selling them at a dollar a pound, and dreaming of the fortune to be made by a ginseng farm. H. A. K.
} 
78 SOME AMERICAN MEDICAL BOTANISTS

Lettsom and Moses Marshall seem to have carried on a brisk correspondence, especially concerning the Talinum teretifolium, hitherto undescribed by botanists. He sends Lettsom three tortoises and some plants, one of which, a Polygala, is thus mentioned in a letter:

"Should this prove to be a new genus, I had designed the appellation of Lettsomia, with this provision, that it might not be unpleasing to thee, and that, in the interim, I should not be able to discover a plant more exalted, conspicuous and worthy." He also asks for a "surgeon's pouch of instruments" to be sent him, and Lettsom hastens to acknowledge the compliment of a floral godchild and encloses ten pounds in case Moses should be out of pocket for seeds asked for. A plant was also named after Moses, but many authorities have claimed the Marshallia for his uncle. Two letters of 1792 have recently come to light which settle the question. Muhlenberg, the correspondent, was himself a leading Philadelphia botanist:

"Dear Sir:

"I beg leave to inform you that the new edition of the Genera Linnaei is safely arrived. I am happy to see that the editor, my friend Dr. Schreber, has done what I requested of him. He has given your name to a hitherto undescribed plant that belongs to the Syngenesia which he 
names the Marshallia. Give my best respects to your uncle, Mr. Humphry Marshall, and believe me with great esteem, sir,

"Your humble servant,

"Henry Muhlenberg."

In a collection of the Marshall papers in the possession of Gilbert Cope, there is the following copy of the reply to this note in the handwriting of Dr. Marshall:

\section{"West Bradford, April I3, I792.}

"Reverend Sir: I have just received yours of the ninth instant, and am much pleased to hear of the arrival of the Genera Plantarum. I am very sensible of the honor done me, through your request, by Dr. Schreber, and think myself but too undeserving. I shall be pleased in your calling on your intended journey, and hope you will consider my uncle's house as a welcome stage. I am, with all due respect,

"Your much obliged friend, "Moses Marshall."

In the glimpses of Marshall seen in biographies of other doctors, he appears as an indefatigable traveller; for he tells Sir Joseph Banks, in I790:

"In May last I set out upon a botanic tour by way of Juniata to Pittsburg, thence southward up the Monongahela upon Green Briar River, over 
New River to Holston, Nolichucky, etc. Then, crossing the high and great chain of mountains, came upon the head waters of Santee in South Carolina, thence by Ninety-six to Augusta and to Savannah Town, and continuing southwest to the river Alatamaha in Georgia. . . . . I then returned to Charleston, making a route of about I6oo miles, and thence by water to Philadelphia. ....

"Notwithstanding the great fatigue, the danger and the expense in travelling, I have in contemplation a second and yet more extensive route."

The suggested exploration of the country west of the Mississippi did not come off in Marshall's time, though Thomas Jefferson was active in planning one and Dr. Caspar Wistar thought he could raise a subscription guaranteeing "one thousand guineas to any one who undertakes the journey and can bring satisfactory proof of having crossed the South Sea."

Like Colden, Marshall entered into civic life, and became Justice of the Peace in I796. He still did a little botanizing and shipped seeds to Europe, but when Humphry Marshall died, leaving a considerable part of his farm west of the Brandywine to Moses, the latter seems to have become a private country gentleman. He built a house and mill on the farmstead; and the village 
of Northbrook, formerly known as Marshall's Mill stands on the land.

About 1797 he married Alice Pennock, and had six children. After his uncle's death there is not much told of his scientific work, and he died on the i 3 th of October, I8I3.

Sketch by Dr. William T. Sharpless. West Chester Daily News, Nov. 22, 1895 .

Memorials of Bartram and Marshall. William Darlington.

The Botanists of Philadelphia. Harshberger. 


\section{CASPAR WISTAR \\ I 76 I - - 8 ז 8}

Wistaria speciosa-NUTTALL

$W$ istaria, the beautiful flowering vine with its rich drooping spring cluster, is known, of course, to all, and "Wistar parties" to most of us; so it comes to pass that the memory of one of our great surgeons is conserved in two emblems of festivity rather than, as he perhaps imagined, in his original observation and Description of the Posterior Portion of the Ethmoid Bone with the Triangular Bones Attached.

His grandfather, Caspar Wistar, a German, came to Philadelphia in 1717 , and Dr. Wistar was born there in $176 \mathrm{r}$. He had the advantage, as a medical student of sitting under Morgan, Shippen, Rush and Kuhn, after which, like most men of his day, he went to Europe, taking his medical degree at Edinburgh University. His inaugural thesis, De Animo Demisso, was dedicated to Franklin and Cullen. He studied under Cullen, and, rate honor for a youthful stranger, was twice president of the Royal Medical Society of Edinburgh.

He was initiated into practice under Dr. John Jones, author of the first work on surgery in 


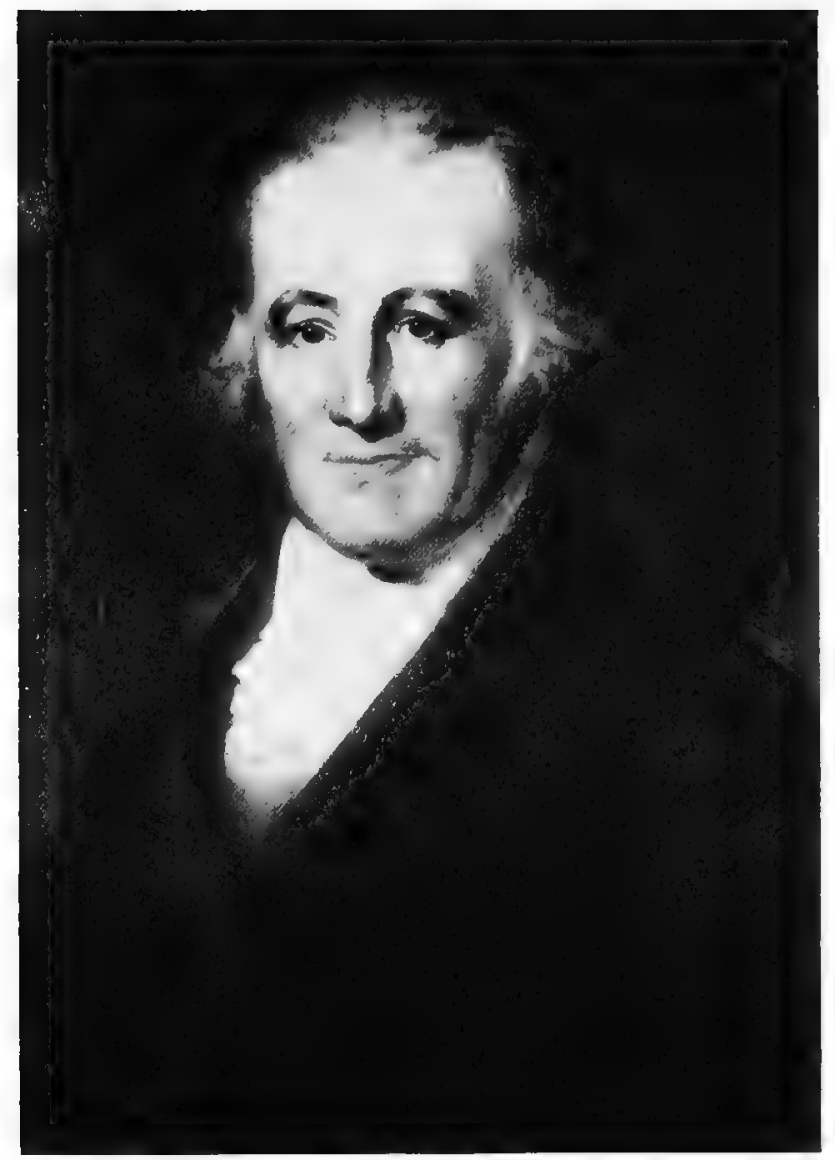

CASPAR WISTAR

(From a family portrail) 

America, which appeared in 1776 , and was appointed Professor of Chemistry and Physiology in the College of Philadelphia, r789. From I 793 to I 8 I o he was physician to the Pennsylvania Hospital. The work of the American Philosophical Society, of which he became president in I 8 I 5 , interested him greatly, and he did much to stimulate the society into collecting the fleeting materials of American history. After the death of Shippen in 1808, he became Professor of Anatomy in the Medical School of the University of Pennsylvania, using such fine descriptive powers that the students flocked to listen; and after the lectures they thronged around him, for his manner convinced them that their interests were paramount to his convenience. He used also to invite them to his house, and Dr. Caspar Morris says, "His urbane manner and happy faculty of engaging them in conversation relieved the frigid formality which usually settles on such assemblages. No sooner would Dr. Wistar enter the room, around the wall of which some twenty or thirty young men but little acquainted with each other were arranged in awful expectancy, than he would draw them into conversation and give freedom to their powers pent up, not so much by ignorance, as timidity."

His sociability and teaching did not leave him much time for writing, but he got through a Sys- 


\section{SOME AMERICAN MEDICAL BOTANISTS}

tem of Anatomy, an excellent work, sent some papers to the Transactions of the American Philosophical Society and made a contribution to the anatomy of the ethmoid bone, as described by Tilghman. Bardeen says Wistar was undoubtedly the first to describe the posterior portion of the ethmoid bone in its most perfect state; viz., with the triangular bones attached to it. Anatomy was his forte, but he was learned also in the natural sciences and collected a number of subjects for the study of comparative anatomy. He kept up a delightful correspondence with Correa da Serra, the botanist, and such men as Humboldt, Soemmering, Camper, Michaux, Marshall and other scientists.

When Humphry Marshall, the great botanist, was seventy-one, young Wistar performed on him the operation of couching for cataract, with partial success, for the old man was at least enabled to distinguish his favorite plants as he walked in his garden. Were the instruments those in the case Wistar afterwards gave to his pupil, Short, another botanist, when the latter left him for his home in the South? I had a pleasant note from Dr. Thomas Wistar of Philadelphia in answer to one of thanks for a portrait of his great uncle:

${ }^{1}$ See Biography of Short. 
“Dear Dr. Kelly:

"Well may you be ' in love with Dr. Wistar.' Every one was in love with him! It was probably his most marked characteristic to draw the admiration, love and respect of all with whom he came in contact. By virtue of his social and scholarly instincts his rooms were informally open to his friends on Sunday, later (by request of his wife) on Saturday evenings, when tea and cake were handed, and every savant from far and near was sure of an invitation to his salon."

Once a week, in his house at the southwest corner of Fourth and Locust Streets, he received his friends and any distinguished strangers who happened to be in town. After Wistar's death his friends kept up these "Wistar Parties" in one another's house for over forty years. The members were fifty in number and members of the American Philosophical Society. S. D. Gross was the one who gave the last party. Wistar died suddenly on January I8, I8I 8, of heart disease; his last words were: "I wish well to all mankind." His memory has been perpetuated in the Wistar Institute of Anatomy and Biology, Philadelphia, and in the Wistaria, concerning which his great nephew, Dr. Thomas Wistar, writes to me:

"As to the naming of the genus Wistaria in honor of Dr. Caspar Wistar, there is not the 
slightest doubt of this fact, although the same honor has been claimed in favor of the late Charles J. Wister (not Wistar) of Germantown, who, with Dr. Wistar, was also a personal friend of Thomas Nuttall, the distinguished botanist, and no mean botanist himself. Dr. Caspar Wistar and Charles J. Wister were relatives, descended from a common ancestor in the Palatinate, near Heidelberg, Germany. The books, so far as I have seen, seem to credit Nuttall with naming the new genus $W$ isteria-its many varieties or species making it quite distinct from the genus Glycinae, with which it was formerly classified. But it is a very fixed and positive tradition in our family that the famous Abbé Correa da Serra gave the name $W$ istaria to this beautiful climber in honor of his friend Dr. Wistar. So I have always heard it stated in the family as a fixed fact, without doubt or question, by my father and several uncles and aunts long since dead, and others, all of whom were contemporaries and ardent admirers of Dr. Wistar, and all persons of the highest reputation for intelligence, truth and probity; yet I have nothing to prove it - no letters or documentary evidenceand it is now rather late in the day to find such corroboration. Our family-the Wistars-have been justly criticised for their seeming indifference or lack of active interest in this matter; but 


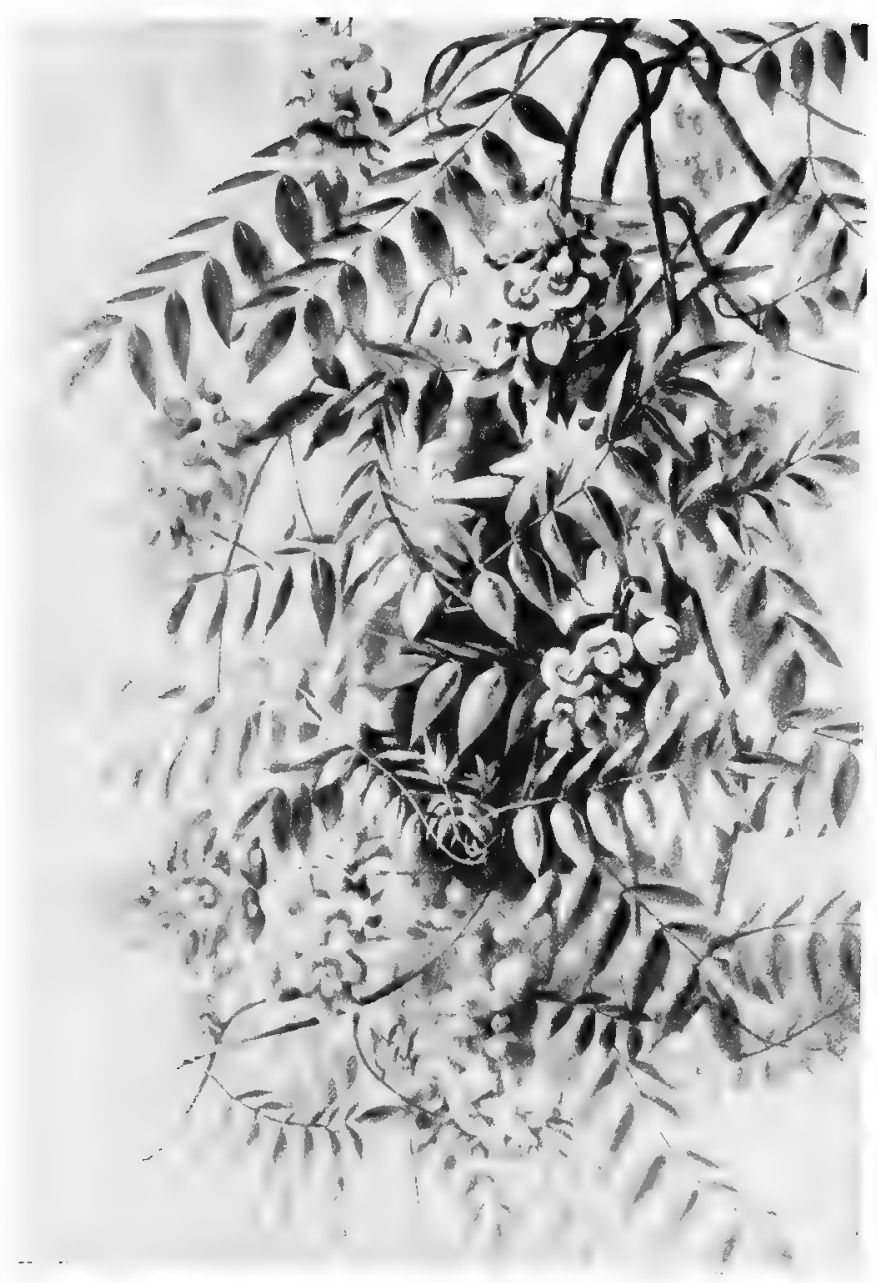

WISTARIA SPECIOSA

(From Southern Wild Flowers and Trees, Lounsberry) 
may we not readily believe that, on the first announcement of the new genus comprising all the varieties or specimens of this beautiful plant, the ardent Abbé himself at once gave it the name $W$ istaria, and that this worthy tribute to their mutual friend and fellow-botanist, Dr. Wistar, was readily accepted and adopted by the distinguished author Nuttall?" 2

His biographers tell us that soon after his return from Europe "he was united in matrimony" with Isabella Marshall, but she died childless. Eight years later he married Elizabeth Mifflin, who made him happy with two sons and a daughter. He was a Quaker and a religious man, and brought up his children to revere God's word, of which he carried a cherished copy given him by Dr. Charles Stuart of Edinburgh. He often took his children out in the carriage with him to talk of the teachings of the Bible.

A Tribute to the Memory of Caspar Wistar. D. Hosack.

An Eulogium in Commemoration of Dr. Caspar Wistar. W. Tilghman.

An Eulogium on Caspar Wistar. C. Caldwell.

Communications from the Wistar family.

${ }^{2}$ Nuttall writes 'W isteria,' but states it was named after Dr. Caspar Wistar. (E. J. Nolan.)

Gray calls it Wistaria and that is sufficient to settle the matter for any lay American community. 


\section{BENJAMIN SMITH BARTON I 766 - I 8 I 5}

Bartonia decapetala-MUHLENBURG

In Lancaster, Pennsylvania, on February Io, I766, Benjamin Smith Barton came into the world with a fair heritage of theology from his father, an Episcopal clergyman, and of science from his mother, sister to David Rittenhouse, the astronomer. The father, Thomas Barton, seems also to have been a scientist, for he was a member of the American Philosophical Society and a correspondent of Linnaeus.

Benjamin Smith was only eight when his mother died, and but fourteen when left an orphan. His taste for botany developed early, and his knowledge of drawing was increased by lessons from Major André, then a prisoner of war at Lancaster, Pennsylvania.

He went to live with an elder brother and became a student at the College of Philadelphia, beginning his medical studies under Dr. William Shippen, Jr. While still a pupil with him, he journeyed with his maternal uncle, David Rittenhouse, and the other commissioners appointed to survey the western boundary of Pennsylvania, 


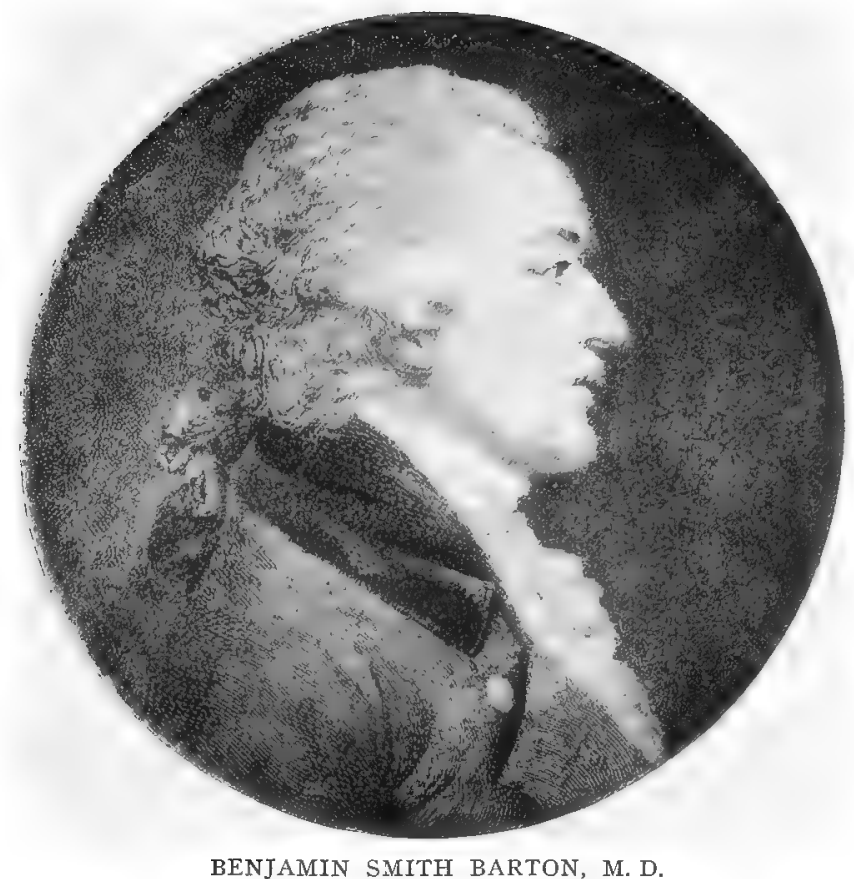

(From a mezzotint by St. Memim, by permission of Professor Uri Lloyd) 

thus having his attention directed to the study of the Indian tribes, a subject which interested him throughout life.

Like many young medical students of those days, he went to Europe to study, and, as the voyage was apt to run into two months, the medical adventurer had time to read and plan his life there.

Except for a few months in London, Barton stayed the whole of two years in Edinburgh, and while there made his first venture in authorship with his Observations on Some Parts of Natural History, to which is prefixed an account of some considerable vestiges of an ancient date which have been discovered in different parts of North America ( 1787).

He left Edinburgh before graduating, and took his M. D. at Göttingen. His reasons for not taking it at Edinburgh are set forth in a letter to his brother, written in London in 1789 in which he states that he preferred getting his diploma from Göttingen because he was dissatisfied with the discourteous manner in which two of the professors at the University of Edinburgh had treated him. However, he did receive several honors, the membership of the Royal Society of Edinburgh, and an honorary premium from that society for his dissertation on Hyoscyamus Niger, the Harveian prize, consisting of a superb quarto edition of the works of William Harvey. 
In 1789 , carrying this prize with him, and a more valuable possession, the friendship of John Hunter and Lettsom, he set sail for America and Philadelphia, where his merits were speedily recognized, particularly as a natural scientist. There was no "Chair of Natural History" in the College of Philadelphia, so a wise Board created one, adding "Botany"; and when the College and the University of Pennsylvania united (I79I), Barton still kept the professorship, along with the post of physician to the Pennsylvania Hospital, taken on in I798. He finally succeeded Rush as Professor of the Theory and Practice of Medicine in I8 I3.

For a busy and not very strong man he wrote a good deal at this time, notably $A$ Memoir concerning the fascinating faculty which has been ascribed to the Rattlesnake, etc., I796. This had a supplement in 1800 and a second edition in I 8 I 4. His Elements of Botany (30 plates) came out in 1803 ; a second edition, in 1812 . The preface says:

"The different branches of Natural History, particularly Zoölogy and Botany, have been my favorite studies from a very early period of my life. The happiest hours of near sixteen years of cares, of difficulties, or of sickness, have been devoted to the cultivation of these interesting sciences. During this long period I have never 
ceased to look forward, as I still look forward, to the time when Natural History, including Botany, shall be taught as an indispensable branch in our University."

In 1805 he started publishing the Medical and Physical Journal, and he also wrote many short articles on topics connected with medicine, history and archaeology, much of his work appearing in the Transactions of the American Philosophical Society.

He was remembered by his immediate successors in the University as a man of extraordinary industry, quick to perceive his own limitations, equally quick to recognize the man who could help, yet keeping step with him for accurate data by means of his wonderful memory and appreciation of fine detailing.

In temperament he was irritable and even choleric, and his manners were consequently variable, impetuous, vehement. So writes his nephew, William P. C. Barton, and this, of a tuberculous, gouty man loaded up with work, is probably accurate. He had married (I797) a daughter of Edward Pennington, of Philadelphia, and had two children, a son, Thomas Pennant, who was American Chargé d'Affaires in Paris, 1836 , and a daughter.

Owing to constant attacks of gout, Barton was unable to take long botanical excursions like his 
fellow-scientists; but having made friends with Frederick Pursh, he financed this botanist for a journey through the mountain chains of Virginia and Carolina, returning through the coast lands ( 1805 ).

In 1807 there came to America a young botanist, Thomas Nuttall," "who visited nearly all the States of the Union, and made more discoveries than any other explorer of the botany of North America." Barton met him in Philadelphia and "omitted no opportunity of fostering his zeal and of endeavoring to extend his knowledge. He had constant access to my house and the benefit of my botanical books."

It is easy to imagine the two men sorting up and classifying the specimens Nuttall found, and the talk they would have of plants not indigenous. Nuttall had but scanty means, Barton an equally scanty store of health. What better solution than their combination of forces?

So, armed with " a considerable collection of manuscript queries and memoranda," Nuttall set off with Bradbury, in April, I8Io, to explore the northern and northwestern parts of the United States. Barton says: "Among a very considerable number of plants which he observed and collected in the course of his journey, there were two species of a genus which he observes

${ }^{1}$ Thomas Nuttall, 1786-1859. 
in his notes to have the 'facies' or aspect of cactus, and which he very properly referred to the class and order of Icosandria monogynia-he names this genus Bartonia. One of the species he calls Bartonia superba and the other Bartonia polypetala. The former he found in flower in August and September; growing all the way from the river Platte to the Andes, on broken hills and the clefts of rocks (Pursh adds, not, I fear, on the best authority, 'and on volcanic soil'). He speaks of it as a plant (herba) about three feet high, whose 'splendid flower expands only in the evening, suddenly opening after remaining closed during the day, and diffusing a most agreeable odour.' It may justly rank (he adds) with the most splendid plants of either America, and very probably inhabits Mexico, if not South America.

"The other species, Bartonia polypetala, he describes as a perennial, growing on gravelly hills, near the Grand Détour, and flowering in August."

Other honors besides floral ones held by Barton included membership of the Imperial Society of Naturalists of Moscow; the Danish Royal Society of Sciences; The Linnaen Society of London; and the Society of Antiquaries, Scotland.

The naming of the plants must have given pleasure to the man who so willingly sojourned with Nuttall. He spent his leisure during this 


\section{SOME AMERICAN MEDICAL BOTANISTS}

time in getting as far as 74 printed pages in his Flora Virginica, and a new edition of the first volume of the Elements of Botany, the second volume of this edition appearing in 1814 ; also in this year the first part of the Archaeologiae Americanae Telluris Collectanea et Specimina, 64 pages, and a new edition of his memoir on the fascinating faculty of various kinds of serpents.

"The pernicious consequences of his midnight and injudicious toils" sapped his vitality. A severe hemorrhage interrupted his work, and in April, I8I5, he tried a sea voyage to France, returning by England. Landing in New York in November, he had not strength to get on home, being laid up for three weeks by hydrothorax. Travelling slowly home, by ship or one of the "highflyer" coaches, he was only fit for bed on arrival. Yet the indomitable spirit of work prevailed, and three days before the end, and in spite of frequent hemorrhages, he wrote a paper - part of which I have quoted-concerning the genus of plants named in his honor, a paper which his nephew, W. P. C. Barton, read at the following meeting of the American Philosophical Society.

Early in the morning of December I9, I 8 I 5 , Barton was found dead in bed. Relatives, hastily summoned, receive no parting words, but dumbly 


\section{ADVERTISEMENTS.}

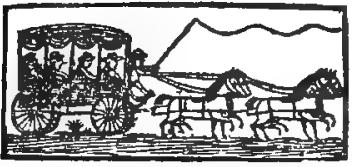

The Swiftsure Line of Stages,

\section{Running from New York and Philadelphia.}

By the shortert, cheapest, safest, and most pleasant road,

Through Newark, Springfield, Scotch-Plains, Union Camp, Bound-book, Millstone. Pennugton, Nevtown, Bustleton, and. Erankford.

\section{THE SWIFTSURE}

Starts from New-York at 9 o clock every day (Sundays except, ed) and arrives at Philadelphia, early the next evening.

From Philadelphia it starts from the Green Tree, No. 50 North Fourth street, at 8 o clock every morning, and arrives at New York early the next evening

Fare for passengers 5 dollars, way passengers 6 cents per mile. Each passenger allowel I l lb of baggage. One bundred and fifty weight ot baggage to pay the same as a passenger.

All baggage to be at the risk of the owner, unless insured and receipted for by the clerks of the different offices. Rate of insirance one per cent.

- Apply to WILLIAM VANDER VOORT, No. $4^{\text {s Court- }}$ land Setreet, N. E. Corner of Greenwich Street, New York, and to JOHN M'CALLA, No, jo North Fourth Street Philade!phus. 




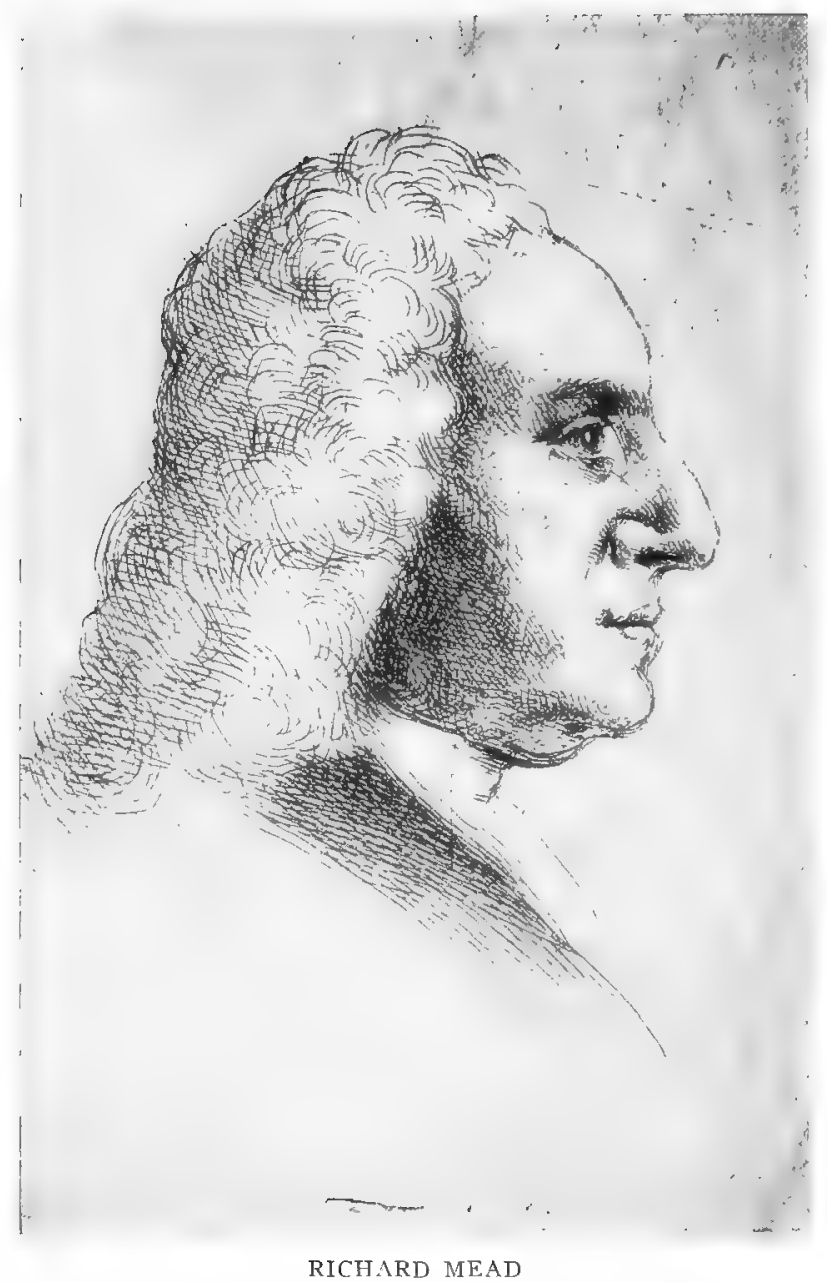

(From the original sketch in the author's possession) 
question the pale lips which had perhaps longed to give some last message-some instructions as to his work. There was so much to be completed; but, noting the list of writings Prof. Uri Lloyd has gathered, these, as well as the prematurely closed life, seem to merit the epitaph "Complete."

There is a remarkable resemblance between the celebrated English doctor, Dr. Richard Mead (1673-1754), and our American worthy, Dr. Barton, as will be seen from a proof etching in my possession. A beautiful flowering plant, the Dodecatheon Meadia (Catesby), is named after Mead.

William Paul Crillon Barton, I783-1856, his nephew, who wrote a good biography of his uncle, must have had much in common with him, for he too was a passionate botanist. It was the fashion of those days for students to take the name of some hero; so William became" William Paul Crillon" Barton, graduated M. D. in I 808 from the University of Pennsylvania, and became a naval surgeon the following year. His thesis On the Chemical Properties and Exhilarating Effects of Nitrous Oxide Gas was the standard treatise of the time. From I816-1822 he was Professor of Botany in the University of Pennsylvania, but he wrote in 1814 a famous Treatise

${ }^{2}$ Bull. of the Lloyd Library, No. i, Igro. 
96 SOME AMERICAN MEDICAL BOTANISTS

Concerning the Internal Organization of Marine Hospitals, and afterwards a Vegetable Materia Medica of the United States, 2 vols. in I, I8I7I 818 , with fifty plates, drawn and colored by the author. Following this, a Compendium Florae Philadelphicae, 2 vols., I818.

While he was Professor of Natural Medicine and Botany at Jefferson Medical College, he published his Outlines of Lectures delivered there ( 1827 ), and during the same time his Flora of North America, I82I.

A mere list of his writings fails to do justice to the wonderful amount of work done by Barton. It would be interesting to know more about the books, and about the writer as an artist, but details are scanty.

Bull. of the Lloyd Library. Reproduction series, No. I, 1900.

Thacher's American Medical Biography.

An account of the life of B. S. Barton, by W. P. C. Barton. The Portfolio, vol. i, No. 4, April, 1816. 


\section{DAVID HOSACK \\ I $769-1835$}

\section{Hosackia bicolor-DOUGLAS}

David Hosack was one of those who live for to-morrow, who doggedly advocate and carry out reforms for which they themselves get neither thanks nor profit. He brought the same keen interest to bear on a new town sewer as on a new view of disease or a new plant for his botanical garden.

He was born on August 3 I, I769, at 44 Frankfort Street, New York, the son of Alexander and Jane Arden Hosack and eldest of seven children. His father came over from Moray, Scotland, as an artillery officer under Gen. Sir Jeffrey Amherst, and was at the retaking of Louisburgh. His mother was of English-French descent.

When about thirteen, young David went to school under the Rev. Alexander McWorter, of Newark, New Jersey; then for a short time to Dr. Peter Wilson, of Hackensack; and finally, in I786, to Columbia College, New York, beginning to study medicine with Dr. Richard Bayley, a New York surgeon, in 1788 , and graduating B. A. from Princeton in 1789 . 
98 SOME AMERICAN MEDICAL BOTANISTS

His first important step after returning to America was the marrying of Catherine Warner, "a lady of great worth"; his next, to remove to Alexandria, Virginia, believing it would become the capital of the United States. But the call of the metropolis was too strong, and he returned in 1792 ; and in that year, seeing the necessity for studying in the European hospitals, left his wife and baby with his parents and spent two years in Edinburgh and London, meeting Robert Burns and all the celebrities of the day, listening to learned divines on Sunday, and getting all he could during the week from men like Munro, Black, Gregory, Duncan, in Edinburgh, and in London consorting mainly with Sir Joseph Banks and his set, who, like himself were genuine botanists.

During the winter in London, with the concurrence of Sir Joseph Banks and other scientists, his Observations on $V$ ision was published in the Transactions of the Royal Society, I794, and the author was duly thanked. He took full advantage of his stay, dissecting under Dr. Andrew Marshall, studying chemistry and mineralogy and visiting the hospitals. He had the good fortune also to make the acquaintance of William Curtis, author of the Flora Londinensis, who had just completed a botanic garden at Brompton, London. Hosack went there nearly every day, 
and in 1794 attended the lectures of Sir J. E. Smith, President of the Linnaean Society.

A tedious journey of fifty-three days in the Mohawk, varied only by an outbreak of typhus on board, brought him again to New York, where he settled down to practise, helped somewhat by friendships made on board. The professorship of botany in Columbia College was offered him in 1795, and in the autumn of that year he and the other young doctors had plenty of opportunity to distinguish themselves, as yellow fever of a malignant type broke out and raged for over four years. Hosack was incessantly busy, but wrote a good deal on the fever, urging always "the sudorific plan of treatment."

Also at this time he took care of Dr. Samuel Bard's patients for a while, so well that a partnership was tendered and accepted. This was a great compliment to Hosack, and-such was the confidence in his judgment-he was often asked by the Board of Health to investigate diseases.

His writings embraced many subjects. Some notable papers, Observations on Glossitis, Cases of Anthrax, Observations on Haemorrhage and the Removal of Scirrhous Tumors from the $B$ reast afterwards appeared in his three volumes of Medical Essays, I824-183o. His Practical Nosology came out in 1819 . 
Having lost his wife and child, he married on December 2I, I797, Mary, daughter of James and Mary Darragh Eddy, and had nine children. The stress of necessity, perhaps, and an immense power for work, made Hosack one of the leading surgeons in New York. He held the chair of materia medica in Columbia College in 1797 ; that of surgery and midwifery in the College of Physicians and Surgeons of New York in 1807 , and there, later, the chair of the theory and practice of physic and clinical medicine.

In 1808 Hosack was the first American to tie the femoral artery for aneurysm. He introduced the method of treating hydrocele by injection as early as I795; and he insisted, in operations, upon the importance of leaving wounds open to the air in order to check hemorrhageadvocated later by Astley Cooper and Dupuytren.

Dr. S. D. Gross writes affectionately of him in his Autobiography, and says:

"I heard him discourse on fevers. He sat in an armchair and read from his manuscript, but frequently indulged in extemporaneous flights, accompanied by flashes of his dark eyes and by graceful gesticulation which enchained the attention of his pupils. His manner was delightful, his voice commanding. . . . After the lecture was over, he said to me: 'The New York Philosophical Society will meet at my house to- 
night and you must not fail to come.' On my arrival ... I was surprised to find a large assembly of gentlemen and ladies, the former including eminent artists, scientists, and authors, to many of whom I was presented by the host. ... The menu embraced every available delicacy, and the wines were of the best quality."

His love of botany led to his founding the Elgin Botanic Garden in I8or, about three and one-half miles from the city of New York, modelling his twenty acres, perhaps, on the plan of those he had seen in London. The expenses were defrayed from his own pocket, including those for a fine conservatory for tropical plants. He had under cultivation nearly I 500 American plants, besides exotics. I expect his floral godchild, Hosackia bicolor, named after him by Douglas, the botanist, was there; also a budding hope, which never came to fruition, for Hosack had imagined the state would take the whole thing over and make it a miniature Jardin des Plantes. They did buy it, but like many similar investments, it was suffered to go to ruin. Imagine Hosack slowly pacing the walks, stopping to adjust a trailer, to nip a dead blossom, his mind full of plans for the various societies of which he was indeed an "active" member and originator. The Historical, Horticultural and New York Literary Societies and the Medical 
and Philosophical Register (1810), all owed much to him; the Journal was run by Hosack and the genial, witty Dr. John Francis. He also founded the Humane Society-one branch for the recovery of persons nearly drowned and another for the relief of the indigent poor; the City Dispensary was remodelled; and he instituted medical lectures to policemen.

As a little play he set to work arranging and augmenting a cabinet of minerals he had brought from Edinburgh-possibly the first collection brought over. He eventually gave this to Princeton, where it was displayed in a special room and supplemented by the gift of a fine lot of works on mineralogy.

Hosack felt that after fifty years of practice he was justified in retiring to his pretty country home at Hyde Park, Dutchess County. He had married his third wife, Magdalena, widow of Henry A. Coster, and with her kept up a good, old-fashioned hospitality, welcoming, alike, famous men and shy ambitious students. Three times, in spite of his busy life and large family, he adopted into his household and trained a poor but clever young man, one of them being Delile, who became superintendent of the Jardin des Plantes, Montpellier.

His son, Dr. Alexander Hosack, tells of the fruit and flower gardens, the conservatories, 
terraced walks, model farm and unconscious thefts of exotics by the villagers, who readily returned the plants, which had been recognized in their cottage gardens. Everything seemed to point to a calm old age; but in December, 1835 , having a presentiment of a coming paralysis, he began trying to write with his left hand. On the eighteenth he had an apoplectic stroke from which he never rallied.

Medicine in America, Philadelphia, 1903. J. G. Mumford.

Amer. Med. Biog., Philadelphia, x86r. S. D. Gross.

Autobiography, Philadelphia, 1887. S. D. Gross.

Boston Med. and Surg. Journ., r868-1869, vol. xlvii.

Mass. Med. Soc., Boston, 1868, vol. xi.

American Med. Biog. Williams. 


\section{WILLIAM BALDWIN}

$$
\text { I 779- I } 8 \text { I } 9
$$

\section{Baldwinia uniflora-NUTTALL}

William Baldwin's name is closely associated with that of Darlington. They were classmates in the University of Pennsylvania; and when Darlington was ill, he says: "My friend Baldwin promptly sought me out, devoted to me every hour he could command .... and night and day, like a ministering angel, was hovering round my bed."

The botanist who makes his biographical début as "a ministering angel "was the son of a Quaker preacher and was born in Newlin, Chester County, Pennsylvania, on the 27th of March, I779. When school days were over, he studied medicine under Dr. William A. Todd, in Downingtown, Chester County, taking his first course of medical lectures at the University of Tennessee in 1802 , though when the second session opened, Baldwin, with a full heart but an empty purse, was already back with Dr. Todd, yet hoping for better times in order to take his medical degree.

This blighting of budding ambition was really the best thing which could have happened, for, in little Downingtown, not big Philadelphia, he met 


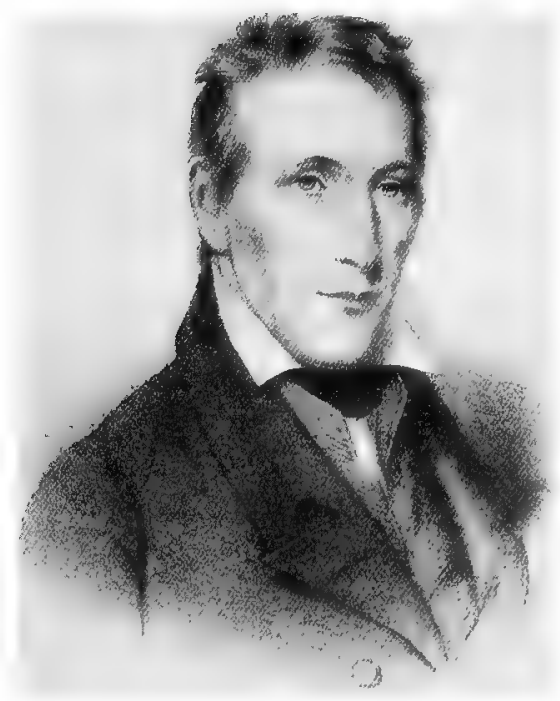

WILLIAM BALDWIN

(From a portrait by Peale) 

the best friend he ever had, Dr. Moses Marshall, son of Humphry Marshall, the botanist, and Dr. Benjamin Smith Barton; and these two, in pleasant companionship of excursion, correspondence and study, made an enthusiastic botanist of Baldwin.

Perhaps because not very strong, or from a desire to travel, Baldwin engaged himself as ship's surgeon on a vessel leaving Philadelphia for Canton. Our enterprising young botanist set out lacking a medical degree, and, as a fellow-passenger laughingly told Darlington, with only three shirts for the long voyage. But he won golden opinions on board as a doctor, and, when he returned in I806, had money enough to study for his M.D. at the University, taking his diploma in 1807 with a thesis: A Short Practical Narrative of the Diseases which prevailed among the American Seamen at Wampoa, in China, in the year 1805 , etc. His grandson tells me that he bought a second-hand copy of this Thesis for five cents, in which Baldwin had written, "To Richard Brown, M. D., with the best wishes of his friend, the author."

He settled down to practise in Wilmington, Delaware, employing his leisure in studying the local flora and in courting and wedding one Hannah Webster, the daughter of a Wilmington druggist, apparently a discreet maid, for Dar- 


\section{IO6 SOME AMERICAN MEDICAL BOTANISTS}

lington says she had "superior intellectual endowments" and her education had "received a classical finish quite unusual among American females at that day.

"They were both Quakers, and were promptly turned out of meeting for being married by a Presbyterian 'hireling preacher.' Baldwin apologized and was taken back. When he entered the navy in $18 \mathrm{r} 2$, he was again expelled from the meeting and was never reinstated, although he made strenuous efforts. He declared that he had gone to the war " not to make wounds but to heal them," but the reply was that war was such a horrible affair that no good Quakermore especially a doctor-should have anything to do with it, and he should at least set a good example to the nation."

As a complement to his botanical pleasures he received one day a letter from a botanist of Lancaster, Pennsylvania, the Rev. Henry Muhlenberg, who said:

"Sir:

"Will you forgive me, if I, as a stranger, intrude upon your studies and beg your acquaintance? Doctor Heister, the present physician of the Lazaretto, informs me that you are a great friend of Botany. I have been the same for nearly forty years and have collected, of American plants in particular, whatever I could get. 
The State of Delaware alone, amongst all others, has contributed nothing to my Herbarium, and I am certain it contains many new and curious plants ...."

Darlington, when writing the life of Baldwin, got possession of the letters which followed and happily includes them in his Reliquiae Baldwinianae.

In I8 I Baldwin reluctantly had to leave Delaware. Hereditary tuberculosis-of which all his family eventually died-made him take to an open-air life in long foot journeys over Savannah and St. Mary's, Georgia, within Indian territory, "his gentle, inoffensive demeanour" overcoming any hostility.

The lurid light of war in 18 i 2 flashed across the path of our perambulating botanist, and American scientists, though zealous for their country, openly lamented the cessation of letters and exchange of specimens with their transatlantic brothers. Baldwin was requisitioned as navy surgeon, the pay being not unwelcome, in view of his young family.

He served chiefly at St. Mary's, Georgia, and when war ceased, seems to have taken to botany as a profession; for, after installing his family again in Wilmington, he spent the winter and spring of 1816-1817 exploring in East Florida, only recalled by the news that he had been 
appointed surgeon-botanist (if such a term may be used) to the frigate Congress, then under weigh for an expedition to Buenos Ayres and other South American ports, there to investigate conditions among the Spanish colonists, and the "vegetable products." He writes to Darlington on the eve of departure:

"Although the state of my health is not such as to render my situation alarming, yet-as life under any circumstances is uncertain-there can be no harm in just mentioning that, in case I should never return, I leave all my botanical concerns to you, who, with the aid of Z. Collins, must make the best of them."

He returned in 1818 rather better in health, and with a fine store of specimens for his friends, and a partly completed catalogue of them. His time, when at Wilmington, was chiefly occupied in describing his treasures-a description never completed, resulting in two papers, ${ }^{1}$ one in the American Journal of Science, I8I9, one in The American Philosophical Transactions, I8I9. His popularity with the government as a wholly trustworthy servant was shown in his appointment (1819) as surgeon and botanist, to go with Major Long up the river Missouri, a most unfortunate voyage from every point of view, judging from

${ }^{1}$ An Account of two North American Species of Rottboellia discovered on the sea-coast of Georgia, 1819. An Account of two North American species of Cyperus from Georgia, etc. 
the last two letters ever received from Baldwin by Darlington:

"This boat, hastily constructed, and built entirely of unseasoned timber, is almost daily in want of repairs, and is so leaky and wet that we have not a dry locker for our clothes. It will be with the utmost difficulty that I shall save any specimens I may collect. . . . . Little opportunity has been afforded to the naturalists to do anything. .... At St. Charles a pack horse was procured for $\$ 50$, and Say, Jessup, Seymour and Peale set out by land. They accomplished no more than they would have done on board the boat, and suffered excessively with thirst and heat in passing burning prairies where no water was to be found. The mail closes presently, and I feel myself too much indisposed to write or to think much."

He tells, in I8I9, of finding a specimen of his own floral namesake in possession of a German botanist: "In looking over his collection I found a Balduinia uniflora. . . . . I informed him the name would not be adopted in this country. He reprobated, and had changed the orthography to Baldwinia." Neither the genus nor the spelling pleased Baldwin, but the name is properly listed by Torrey and Gray as Baldwinia uniflora, though Lindley ${ }^{2}$ gives Balduina."

'Gray's Botany.

Lindley (The Vegetable Kingdom), pp. 334-7Ir. 
I IO SOME AMERICAN MEDICAL BOTANISTS

A letter received recently from his grandson, Dr. Edward Baldwin Gleason, is not without interest:

"My dear Dr. Kelly:

"October 30, I9I2.

"Your letter of the 24th relative to my grandfather, Dr. William Baldwin, reached me. I went with Dr. Seneca Egbert to the Academy of Natural Sciences and was shown some dried plants gathered by my grandfather in Georgia and the Bermudas about roo years ago. These plants, a part of the von Schweinitz collection, were in an elegant state of preservation and compared somewhat favorably with plants of the same family recently collected by a member of the Academy.

"Nuttall's name for the plant he named after grandfather was Baldwinia uniflora. The following is from Genera of North American Plants and a catalogue of species to the year $I 817$, by Thomas Nuttall, F. L. S., Philadelphia, I8 18, p. I75.

" 688. Baldwinia. Calex imbricated, foliacious and squarrose; rays rubrifed; receptacle hemispherical, corneous, cellular, seeds immersed, pappus foliacious, awnless, erect, about ten-leaved. Dedicated as a just tribute of respect for the talents and industry of William Baldwin, M. D., late of Savannah, Georgia, a gentleman 
whose botanical zeal and knowledge has rarely been excelled in America.'

"I was greatly surprised that the two officers of the Academy whom I met seemed to know all about my grandfather and his work as a botanist. One of them asked me what was the probable date of his visit to the Bermudas, when he had been in conversation but a few moments, and without hesitation selected part of a portfolio which contained plants collected by my grandfather in that locality."

The next news Darlington had of his friend was an official letter announcing his death on the Ist of September, I819, at Franklin, on the banks of the Missouri, in the home of his friend John Lowry.

Mrs. Baldwin was quite willing to let Darlington have the Herbarium; her husband had written to her five days before his death reminding her of his promise, but Darlington's compassion for the young widow and four little children induced him to try to sell it, its obvious value prohibiting his buying it himself at the price he could afford. Zachary Collins, the botanist, bought it and meant to place it in the Philadelphia Academy of Natural Sciences; but his representatives sold it to the Rev. L. D. de Schweinitz, who finally bequeathed it to the Philadel-

${ }^{3}$ Lewis David von Schweinitz, botanist, I780-1834. 


\section{2 SOME AMERICAN MEDICAL BOTANISTS}

phia Academy. In it he found 3,000 species not in his own collection. Darlington tried in vain to get a small government pension for his friend's widow, and doubtless the unexpected refusal meant in roads into his own scanty income. He gave also most generously of his leisure in sorting over Baldwin's manuscripts and letters and has transmitted to us the Reliquiae Baldwinianae ( 1843 ). In this work he gives no published writings from Baldwin, save the two papers mentioned; the other manuscripts unpublished came into Dr. Torrey's possession and, though in a fragmentary state, were used as contributions for his monograph of the Cyperaceae, and for Gray's monograph of Rhynchospora, in the Annals of New York Lyceum of Natural History, vol. iii.

At the beginning of his biography of Baldwin, Darlington has this quotation:

\section{“Manibus date lilia plenis}

Purpureos spargam flores animamque nepotis

His saltem accumulem donis, et fungar inani

Munere!" (Virgil, Aen. 6, 883-6.)

("Bring me handfuls of lilies, that I may strew the grave with their dazzling hues, and crown, if only with these gifts, my young descendant's shade and perform the vain service of sorrow.")

-Conington.

Reliquiae Baldwinianae. W. Darlington. 1843 .

Memorials of Bartram and Marshall. W. Darlington. I849.

Personal Communication from his grandson, Edward Baldwin Gleason. 


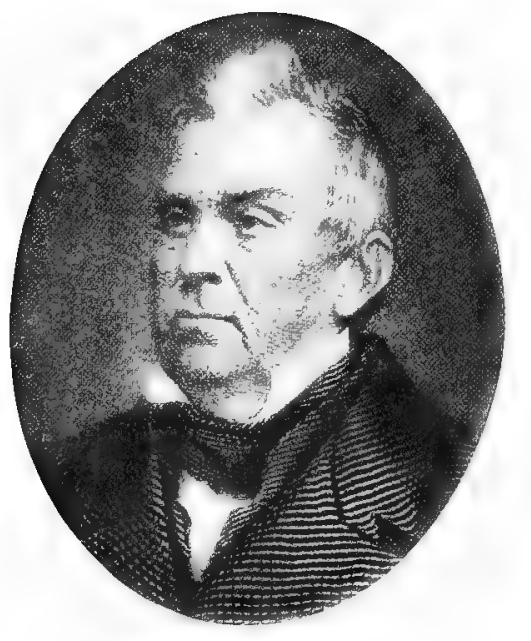

WILLIAM DARLINGTON

(By permission of Professor IIarshberger) 


\section{WILLIAM DARLINGTON \\ 1 $782-1863$}

Darlingtonia Californica ${ }^{1}$ - TORREY

Born in Chester County, Pennsylvania, a doctor, botanist, and author, Darlington was one of a famous group of scientists exploring, writing and keeping up a keen scientific correspondence with each other; from Europe to America, from America to Europe, news of fresh plants, packets of seeds, graceful congratulations were sent, Linnaeus being the brightest star and one whose opinion was first sought.

The seeming hardship of having to work on a farm, the outdoor life, may have indirectly helped William Darlington's botanical interests. His great-grandfather, Abraham Darlington, had come over from England to Pennsylvania when a young man, and settled near Chester. William was the eldest child of Edward and Hannah Townsend Darlington and one of five sons. He had a common school education, but, hungry for more, persuaded his father to let him

${ }^{1}$ The name Darlingtonia had been previously otherwise used. This plant will always be popularly known as "Darlingtonia," but most careful botanists now use the technical name Chrysamphora. (J. H. Barnhart.) 


\section{I4 SOME AMERICAN MEDICAL BOTANISTS}

study medicine with Dr. John Vaughan, of Wilmington, Delaware. He took also private French lessons, studied hard at Latin, Spanish and German and received his medical degree from the University of Pennsylvania in I804.

He had the good fortune of being able to attend the botanical lectures of Dr. Benjamin S. Barton, and it is easy to imagine the shoots of his botanic ideas taking root in the firm earth of accurate knowledge.

A voyage to India as ship's surgeon gave him leisure for study and reflection, but does not seem to have given him "travel fever" also, for, the following year, he settled down to practise in West Chester, after marrying Catherine, daughter of Gen. John Lacey, of New Jersey.

In 18 r 2 international science yielded to international strife, and Darlington became major of the "American Grays," organized to defend Philadelphia. Shortly after he figured as a politician advocating the restriction of slavery. He was nominated by the secretary of war as visitor to West Point. He served on the Board of Canal Commissioners to connect the Great Lakes with the Atlantic, yet, in the midst of much civic business, he found time to botanize and found the Chester County Cabinet of Natural Science and to publish, in 1826 , his Florula Cestrica. Later, in 1837 , a new edition appeared as Flora Ces- 
trica, both being a description of plants growing in Chester County, Pennsylvania. With some confrères he founded and became president of the Medical Society of Chester County, a happy union which drew together all that was best in the local medical world.

One thing which pleased him greatly was the perpetuation of his name in a flower. Professor De Candolle of Geneva named a genus after him, but it was not sufficiently distinct; another friend, Professor Torrey of New York dedicated to him a finer plant, of the order Sarraceniaceae, growing in California.

Professor Torrey, writing On the Darlingtonia Californica, tells us: "This new Pitcher plant was first detected by Mr. J. D. Brackenridge, who found it in a marsh, bordering a small tributary of the Upper Sacramento, a few miles south of Shasta Peak..... Without the flowers (it being October) nothing further could be determined respecting it; but from the bracteate scape and deeply parted lamina or appendage of the leaves, it seemed more probable that it was distinct from Sarracenia." Dr. G. W. Hulse, of New Orleans, found it in the same region many years later, and sent one in flower to Torrey; so the latter goes on to say: "The plant proves to be generically distinct from Sarracenia as well as

'Smithsonian Institution Papers, April, 1850. 


\section{6 SOME AMERICAN MEDICAL BOTANISTS}

from the genus Heliamphora of Bentham, and I take pleasure in dedicating it to my highly esteemed friend, Dr. William Darlington .... , whose valuable botanical works have contributed so largely to the scientific reputation of our country. The genus dedicated to this veteran botanist by De Candolle has been reduced to a section of Desmanthus by Bentham, and a Californian plant, on imperfect specimens of which I have recently indicated a genus under this name, proves to be only a species of Styrax."

Darlington certainly deserved the honor, for a more generous man never lived. This was shown in his gathering together all the letters and memoranda of Dr. William Baldwin, a zealous botanist, who died still young while on an expedition up the Missouri. He called the book Reliquiae Baldwinianae, $\mathrm{I} 843$, and, six years later, made all botanists his debtors by his loving work shown in The Memorials of John Bartram and Humphry Marshall, I849, the careful footnotes alone constituting valuable references to the botanical side of that period. Between these two volumes another was written, a result of his observation of the unscientific farming going on around him, a book which was of genuine service; this was his Agricultural Botany, 1847.

He willed that his herbarium and all his botanical works should go to his own county, where 


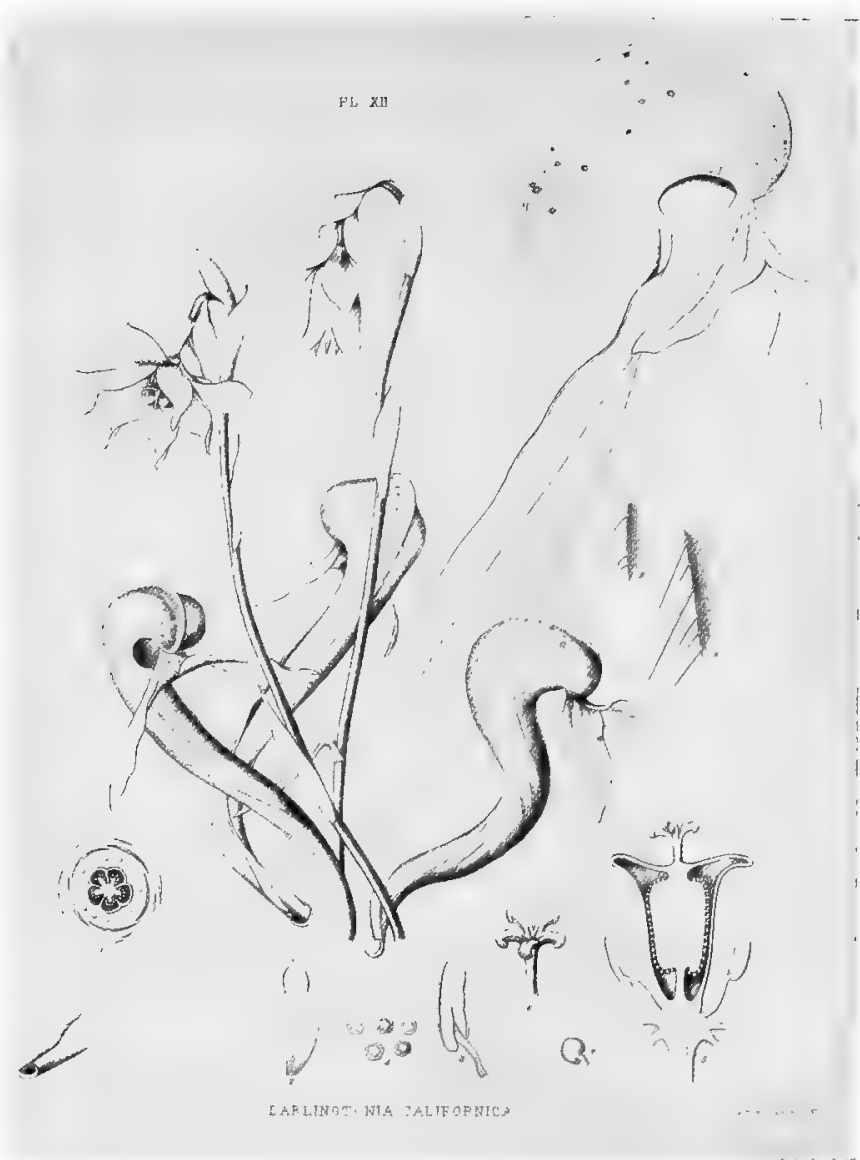

DARLINGTONIA CALIFORNICA

(From The Smithsonian Contributions to Knowledge, I 850 ) 

they are still in the museum of the West Chester State Normal School, now, like many another valuable collection, too little known, but erstwhile a fount of continual joy to the great collector, adding zest to his correspondence with fellow-botanists on both sides the Atlantic, and the more than forty learned societies which elected him to membership.

Darlington had a great sorrow in 1845 , when his son, who had served in the navy for seventeen years, died of disease contracted on the coast of Africa. Mrs. Darlington died shortly after, and in the spring of 1862 Darlington had a slight attack of paralysis, followed in ${ }^{2} 86_{3}$ by another, from which he died on Thursday, April 23, I863, nearly eighty-one years old and with mind still unimpaired. He was buried in Oaklands Cemetery, Philadelphia, and on his tomb is carved:

$$
\begin{aligned}
& \text { Plantae Cestrienses } \\
& \text { quas } \\
& \text { dilexit atque illustravit } \\
& \text { Super Tumulum ejus } \\
& \text { Semper Floreant. }
\end{aligned}
$$

Tr. Med. Soc. Penn., Phila., I863.

Memorial of William Darlington, by W. T. James. West Chester, 1863. 


\section{JAMES MACBRIDE \\ 1784- 1817}

\section{Macbridea pulchra'-ELLIOTT}

\section{Although Macbride's name figures in the indi-}

ces of several volumes, yet, taking all the references together, very scanty information can be had concerning him. The fact that Dr. Stephen Elliott dedicated to him the second volume of his Sketch of the Botany of South Carolina and Georgia (1824), and named the Macbridea pul-

1 "This plant, nearly allied to Melittis, appears to differ in its calyx, corolla, anthers and perhaps by its glands. I have therefore inserted a minute description, that it may be compared with that genus. Its habit is peculiar. Each whorl, when in flower, appears to be on the summit of the stem. Two flowers generally shoot up at a time. These are large for this order, rather exceeding an inch in length, and are fancifully said to resemble two ears. Sometimes, though very rarely, all the flowers of the whorl expand at the same time. While the first whorl is flowering, the stem insensibly extends; and, when the first flowers have decayed, a second whorl appears on the summit of the stem, ready to expand its two most forward buds. There are rarely more than three or four whorls on each stem. I have named this genus in commemoration of the late Dr. James Macbride, whose untimely death, Medicine and Natural History, and an admiring country equally deplore.

"It grows in the narrow swamps through the pine barrens in the middle districts of Carolina, and is very abundant between Saltcatcher bridge and Murphy's bridge on the Edisto river; it flowers from August to September." (Elliott's Botany of S. Carolina and Georgia, vol. ii, 1824.) 
chra for him, indicates that the writer presumed James Macbride to be well known.

Born in 1784 , he graduated from Yale in 1805 and afterwards studied medicine. He then settled to practise for a while in Pineville, South Carolina, but later removed to Charleston, where he died of yellow fever in $18 \mathrm{I} 7$, only thirty-three years old, yet with renown as a doctor and a scientist.

Botany was clearly his favorite study and his chief writings on this subject are in the Transactions of the Linnaean Society.

Memorials of Bartram and Marshall. W. Darlington.

Sketch of the Botany of South Carolina and Georgia. Stephen Elliott. 


\section{JACOB BIGELOW \\ I 787 - I 879}

\section{Bigelowia Menziesii ${ }^{1}$-DE CANDOLLE}

It must ever prove a source of gratification to lovers of natural science that the boys in the past, studiously inclined, were often tolerantly or resignedly allowed to "waste their time" in field and wood, making boyish "collections" and harvesting observations. Jacob Bigelow says he spent his long leisure, until he was thirteen, "roving about the woods, puzzling myself with speculations on natural objects and taking intense delight in the construction of miniature saw mills, machinery for entrapping rats and squirrels, and rude attempts at drawing and carving."

He speaks laughingly of his first lesson in botany; it was given when, as a little boy, he asked a learned gentleman the name of the plant "Star of Bethlehem": "That? Why, that's grass, you little fool "!

Massachusetts gave us this great educational reformer, who was one of America's most learned botanists and was closely associated with the lead-

${ }^{1}$ But neither this nor any of the four earlier Bigelovias or Bigelowias, are now tenable. 


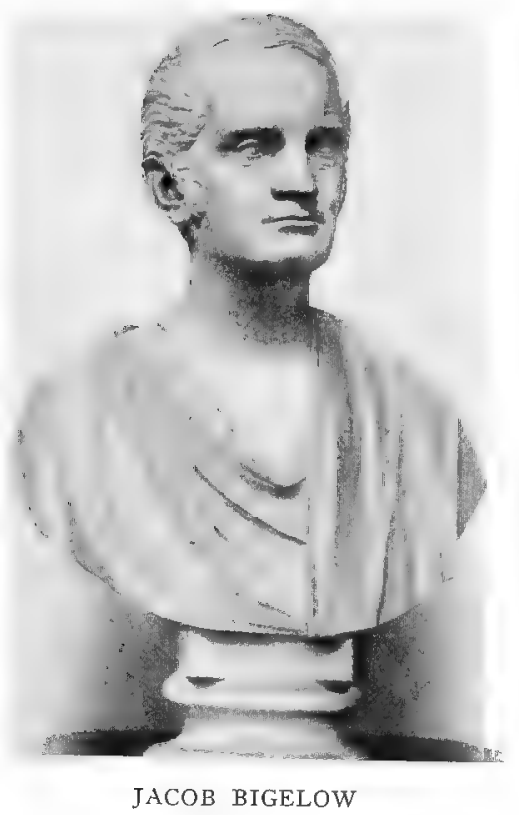

(Frontispiece, A Memoir of Jacob Bigelore, G. E. Ellis) 
ing scientists of the world. $\mathrm{He}$ was of $\mathrm{New}$ England ancestry, his people coming over about I640 and settling in Watertown, Massachusetts. Jacob Bigelow, father, was a Congregational minister, who married a daughter of Gershom Flagg.

The son was born February 27, 1787, his childhood being passed in the country at farm work, with scanty schooling. Painfully his father managed to send him to Harvard, where he graduated in 1806 , and in 1808 attended the medical lectures there as a pupil under Dr. John Gorham and taught in the Boston Latin School. Then he went to the University of Pennsylvania to attend the lectures of Rush, Wistar, Barton and Coxe and to receive the doctor's degree ( $18 \mathrm{IO}$ ).

He was a private pupil under Benjamin Smith Barton, and so had his botanical knowledge considerably augmented. Some years previously, Ward Nicholas Boylston had instituted a prize for the best dissertation on a medical subject, and student Jacob says:

"So great was my diffidence at the thought of presuming at a mark far beyond my reach, that I concealed my purpose from every one and wrote a long essay on Cyanche Maligna, in winter time, in a cold chamber, being obliged to wear a glove on my right hand to preserve the flexibility of my fingers." At last, when it was fin- 


\section{I22 SOME AMERICAN MEDICAL BOTANISTS}

ished, he went out one dark evening and left it at the Committee's rooms; but it was returned as too late for examination, and he tried again next year with Phthisis Pulmonalis, sending in the first paper also. Both received prizes, and the award was his once more the next year for his Treatment of Injuries occasioned by Fire and Heated Substances.

So promising were his abilities at this time ( $18 \mathrm{r}$ ) that Dr. James Jackson invited him to become his partner and "be at hand at all needed times." Bigelow easily succeeded in that part of the practice which Jackson declined, and was also his successor as president of the Massachusetts Medical Society and of the American Academy of Arts and Sciences.

"Finding that a considerable taste had sprung up among my pupils for the study of plants, I began to collect materials for a description of the native plants of Boston and its vicinity, which I published in 1814 under the name of Florula Bostoniensis. This limited volume passed through three editions with enlargements, and was for several years the principal book used by herborizers in New England. ....

"The Abbé Correa da Serra, when he visited Boston, perused my herbarium and afterwards gave me letters to eminent botanists of Europe, so that I was able to open a correspondence and 
exchange specimens. . . . Genera of plants were named for me by Sir J. E. Smith in the supplement of Rees' Cyclopaedia, by Schrader in Germany, and by De Candolle in Paris. Of these the last only stands, the two others having been previously appropriated to other botanists."

Gray says, in his tribute to Bigelow in the American Journal of Science and Arts (I879 ?) that more than thirty species of Bigelovia, besides one from Mexico and two from the Andes of South America, now commemorate him. Most of them were described by Gray himself.

Bigelow was awakening an interest in a science for which the literature was scanty; some old works were in the libraries, but, with their Latin and unnecessarily complicated nomenclature, they were not adapted to students.

In 1817 , Bigelow, with two others, sat very seriously as a committee to receive the depositions of eight persons who had seen a sea-serpent off the coast. A time-stained pamphlet of fifty-two pages, with engravings, contains the Report of a Committee of the Linnaean Society of New England, relative to a large Marine Animal, Supposed to be a Serpent, seen near Cape Ann, Massachusetts, in August, I8I7, and a copy was sent to Sir Joseph Banks in London, who ventures, though courteously, to express a little incredulity "which future observation will no doubt clear up." 


\section{I24 SOME AMERICAN MEDICAL BOTANISTS}

Another event in 1817 occupied the professor's serious attention quite as much as the sea-serpent: this was the finding of a wife-Mary, daughter of Col. William Scollay, who bore him five children, one of them Henry Jacob Bigelow, and gave him " more than fifty years of uninterrupted happiness." There is no record that he consulted Sir Joseph Banks this time concerning the correctness of his discovery.

At thirty, then, this young professor is found with ability and courage equal to all the many duties which crowded his day; moreover, he had been made Rumford Professor of the Application of Science to the Useful Arts, which was worth \$I,OOO annually. Most of the lectures were embodied in his Elements of Technology (Boston, I 829).

"In I818, I began," he says, "to publish a work on American Medical Botany, to consist of six half-volumes. .... I involved myself in the difficult responsibility of investigating the whole subject and of furnishing sixty plates and sixty thousand colored engravings, which were to be engraved in outline and the impressions separately colored by hand. I soon found that I had greatly over-rated the ability of my artists and under-rated the time and labor necessary to oversee the proceedings of the work. I came to the conclusion that the only way of extricating myself 
from the difficulty was to invent some new mode of printing the impressions at once in colors from the copperplates. After many trials and experiments a tolerably successful mode was discovered, which consisted in engraving the plates in aqua tinta, thus producing a continuous surface, to the parts of which separate colors could be applied, and the surface wiped off in different directions so as not to interfere with each other."

The title of the book is American Medical Botany, being a collection of the Native Medicinal Plants of the United States, etc. The third volume came out in 1820 ; the finish both of the pictures and of the text is such that it would be creditable even to-day. It is a prize eagerly coveted by collectors, but diligent search has as yet given me only two parts of the three volumes.

When the great cholera epidemic of 1832 in New York carried off some 3,000 victims, Boston's death-roll numbered only one hundred, owing to the authorities being wise enough to adopt the stringent sanitary precautions urged by Bigelow, who, with Ware and Flint, offered his services as investigator of the conditions in New York.

Those who used the new Pharmacopoeia of the United States in I 820 must have been grateful to Bigelow for his wisdom in dealing with his assignment-the list and nomenclature of the 


\section{26 ȘOME AMERICAN MEDICAL BOTANISTS}

materia medica. Spaulding, of New York; Hewson, of Philadelphia; Ives, of New Haven; and De Butts, of Baltimore, were his co-workers. Bigelow, disregarding the double or triple names in the English pharmacopoeias, let Gentiana appear without the "lutea" or "radix" and treated all names in the same way. "This simple nomenclature continues to be used in this country and seems likely to supersede all others, at least so long as medicine continues to be made a mystery, and pharmacy a trade, and therapeutics almost a pseudo-science."

Bigelow at middle age was visiting physician to the Massachusetts General Hospital, was Professor of Materia Medica at Harvard, had an enormous consulting practice, wrote frequently for the press, and keenly worked for reform in the practice of medicine. He had clear vision, and for many years, in season and out of season, insisted particularly upon the self-limited character of disease. In 1835, when he read an address with this title before the Massachusetts Medical Society, the effect was instantaneous and immense. O. W. Holmes says, "This remarkable essay has more influence on medical practice than any other similar brief treatise." The paper is bound up in a little volume entitled Nature in Disease and Other $W$ ritings, 1854. 



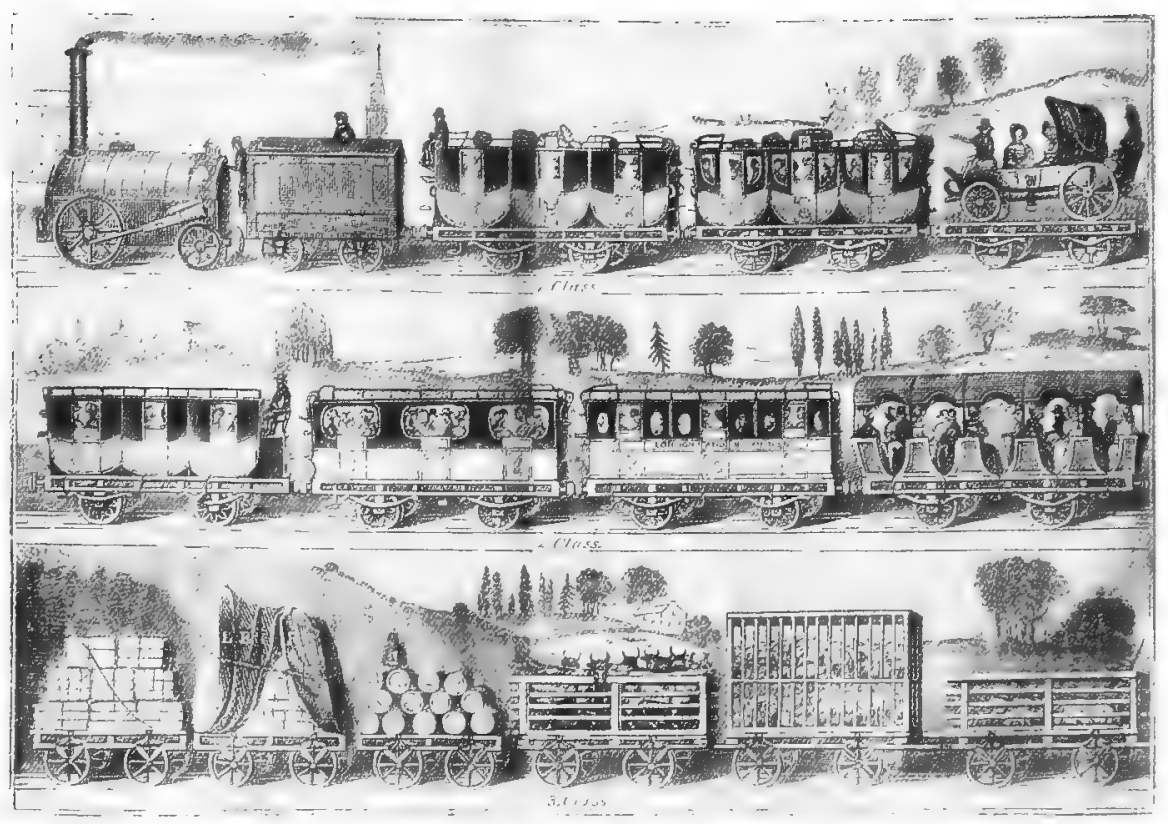

TRAVELLING IN EUROPE, I830, AT "THE HIGH SPEFD OF 30 MILES AN HOUR" 
His lectures on the reform of medical education, at a time when doctors easily obtained degrees or practised without them, provoked much discussion both here and in Europe. Lecky wrote a strong letter of dissent on receipt of Bigelow's Modern Inquiries, but Lyell, Huxley and Spencer "heartily thanked "the writer.

After I 835 , he began to get a little holidaying into his life and made excursions over the country, also a second journey to Europe in 1848 . I 870 saw him, an old man, with film impairing his vision, crossing the continent to San Francisco. "He takes note of the Echo Canyon, the Desert and Alkali Pines, the oak groves and the wild flowers . . . . he goes to the valley in which the gigantic Sequoias stand in their marvellous grandeur. He had still a degree of bodily vigor on his return sufficient for active exercise for three more years."

"A gathering of cataracts upon his eyes was his first disablement; then a partial dullness of hearing; then a gentle but sensible dealing from paralysis." For the last five years of his life he was sightless and generally in bed. He reminded a friend who pitied his blindness that we usually close our eyes before sleeping and he was only doing it a little earlier. News of the outside world, in talk and book, still interested him greatly, while the droll side of happenings met, 
as ever, a quick responsiveness. Now, as always, his home was the best place he knew. When active, he used to rush upstairs to the children, for whom he made toys and planned tearless paths in learning's stony ways. Music, modelling, botany were his refreshment. His religion, not for speech, discussion or profession, was that of a serious man living very near the realities of life! Unforgotten to the end, though long inactive, he died in January, 1897 , and was buried in the beautiful Mount Auburn Cemetery, which he himself had originated.

Abridged from Surgical Memoirs and Other Essays. Dr. J. G. Mumford, New York, I908.

Memoir of Jacob Bigelow. G. E. Ellis. Cambridge, 1880.

Boston M. and S. Jour., 1879, 3. s., xvii. Am. J. Sci. and Arts, 1879. New Haven, 3. s., xvii. 


\section{CHARLES WILKINS SHORT}

$$
\text { I 794- } 1863
$$

Shortia galacifolia - GRAY

Among the pupils who loved Wistar, and one ever a welcome guest at his home, was Charles Wilkins Short, a Kentucky lad born in I794, the son of Mary Symmes and Peyton Short, who owned a farm of several thousand acres. Gross says that Short, as a boy, was "noted for his exemplary conduct and love of nature "; also that he was "of medium height, with blue eyes and an ample forehead, and a smile radiant with goodness and beneficence."

Dr. Frederick Ridgeley, of Kentucky, gave him his first medical training; then followed two years with Dr. Wistar in the University of Pennsylvania. A thesis on The Medical Virtues of Juniperus Sabina marked his graduation there in 1815 , and Wistar, who had become warmly attached to his pupil, gave him a cherished case of eye instruments when he left for home. That same year he devoted some of his time to wooing and wedding Mary, only child of Armistead and Jane Churchill. The young couple travelled home to Kentucky in a spring- 


\section{I3O SOME AMERICAN MEDICAL BOTANISTS}

cart, Short botanizing on the way; and the journey, whether owing to Mary or to the specimens, is described as " replete with interest." So also was the scene of his first settled practice, Hopkinsville, then a wild, romantic district, where he gathered patients and plants.

The botanical journeyings must have been very interesting. Picture Short, his brother, and three other botanists setting out " in a light covered wagon to study the autumnal flora of the prairies, travelling over 400 miles in Illinois." What careful pressing and storing in the evening, with thoughts flying ahead across the Atlantic to botanical comrades destined eventually to receive some of the spoils of the day!

Short's botanical colleagues always regretted that he could not or would not write a book concerning his researches; but he never took to the idea, and his chief writings are Notices of Western Botany and Conchology, a paper published jointly by himself and Mr. H. Halbert Eaton (1830) ; Instructions for the Gathering and Preservation of Plants in Herbaria; a Catalogue of the Plants of Kentucky, which had two supplements; The Bibliographia Botanica (1836); Sketch of the Progress of Botany in Illinois ( 1845 ) ; and, with his colleague, Dr. John Easton Cook, he founded The Transylvania Journal of Medicine, in 1828 . 


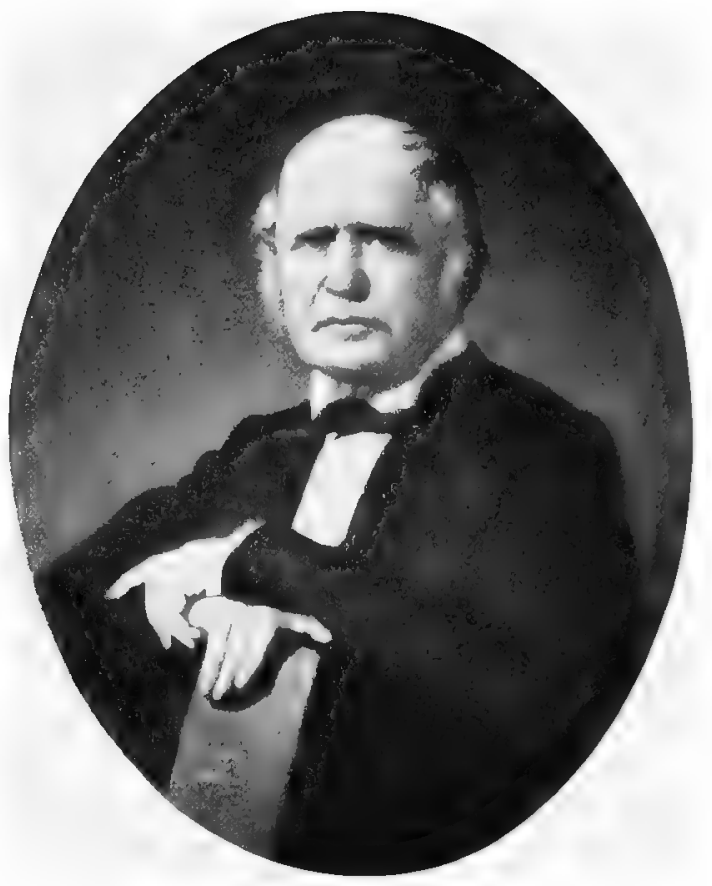

CHARLES WILKINS SHORT

(Frontispiece, A Sketch of C. W. Short, S. D. Gross) 

Short's chief usefulness in the botanical field was mainly owing to the great extent and the particular excellence of his personal collections; also to the generous profusion with which he distributed them, far and wide, among his fellowlaborers in this and other lands. $\mathrm{He}$ and $\mathrm{Mr}$. Oakes - the one in the West and the other in the East, but independently-were the first in this country to prepare, on an ample scale, dried specimens of uniform and superlative excellence, and in lavish abundance, for the purpose of supplying all who needed them.

He soon got into touch with scientific men everywhere by exchanging specimens. This gave him reputation, and led eventually to an invitation, which he accepted, to become professor of natural medicine and medical botany in Transylvania University, where Benjamin W. Dudley and Daniel Drake were his colleagues. Short's heart was thoroughly in his work, and he stayed there until internal dissensions in 1837 made him and Drake accept the same professorships in the University of Louisville.

Twelve years there as teacher made Short crave more time for private work; so, in I 849 , "he retired to Hayfield," five miles out of Louisville, and "enjoyed an elegant leisure" in his herbarium, helped by his daughters; but he planned and financially helped several distant 


\section{I32 SOME AMERICAN MEDICAL BOTANISTS}

and difficult botanical expeditions, and bought the rich herbarium of Berlandier, the fruit of research in Texas and Mexico. He gathered books also-some 3,000 of them-one-fourth of them rare botanical works. His vast collection of dried specimens passed into the hands of the Academy of Natural Sciences, Philadelphia. This was originally meant for the Smithsonian Institution, but they had no room for it.

One grieves a little to learn that a curious debility and ennui came over him when he was sixty-seven. The old interests failed to attract; and two years later, pneumonia, following on typhoid, ended his life on March 7, 1863.

Gray, writing to Sir William Hooker concerning him, says: "He was one of our oldest botanists, the best of men and kindest of friends. I feel the loss very much. Although we never met, he was one of my most valued friends."

His name is commemorated by a number of plants: "Genus Shortia, galacifolia, founded by Prof. Asa Gray, on a plant of the Pyrola family, discovered by Michaux on the mountains of North Carolina ; a cruciferous plant, $V$ esicaria Shortii, described by Torrey and discovered by Short on the banks of Elkhorn Creek, Lexington, Kentucky; a leguminous plant, Phaca Shortiana, 


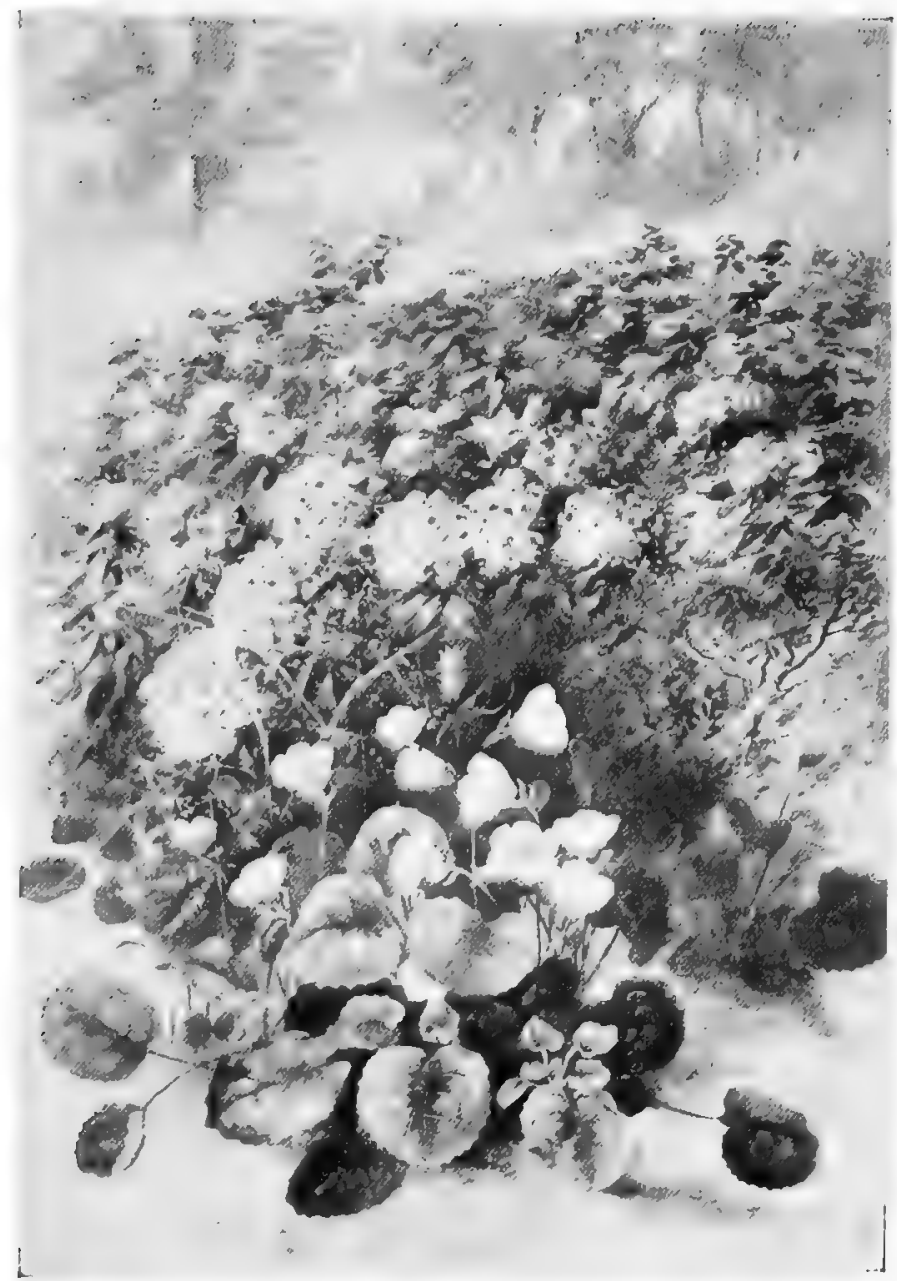

SHORTIA GALACIFOLIA

(From Sowthern Wild Flowers and Trees, Lounsberry) 

of Nuttall, found in Missouri; Aster Shortii, so named by Boott, growing in Ohio, Wisconsin and other regions; Solidago Shortii, of Torrey and Gray, a goldenrod discovered at the Falls of the Ohio; Carex Shortiana, of Dewey, extending from southern Pennsylvania beyond Illinois." 1

The story of Shortia, which was lost for nearly fifty years, is full of interest.

"When Dr. Gray was in Paris, in 1839 , he observed in the herbarium of the elder Michaux an unnamed specimen of a plant. It consisted merely of the leaves and single fruit, and its label stated that it had been collected in les hautes montagnes de Caroline. On his return to America, Dr. Gray hunted assiduously for the plant in the mountains of North Carolina, but wholly without success. Two years later, however, Dr. Gray ventured to describe the plant, which had, he said, the habit of pyrola and the foliage of galax, and dedicated it to Dr. C. W. Short, the eminent botanist of Kentucky. Henceforth no botanist ever visited the region in North Carolina without searching for Shortia as if for the philosopher's stone. In the meantime, Dr. Gray found among a collection of Japanese plants a specimen almost identical with that of Michaux, a coincidence which strengthened his faith in the existence of the American species. It was not until

${ }^{1}$ Biographical Sketch. S. D. Gross. 1865. 


\section{I34 SOME AMERICAN MEDICAL BOTANISTS}

I 877, however, that it was found, and then quite accidentally, by G. M. Hymans, a boy who knew nothing of the good luck that had befallen him. He had picked it up on the banks of the Catawba River near the town of Marion, in McDowell County, North Carolina. Fortunately his father was a professed herbalist, and, through a correspondent, finally learned the true nature of the plant. It had been collected when in flower, and thus Dr. Gray was able to substantiate his original ideas of the genus and perfect its description. He still clung to the idea that its natural habitat must be, as Michaux said, in les hautes montagnes de Caroline, arguing that the point on the Catawba where it had been found was an outlying haven to which it might have been washed. So with renewed energy it was searched for through the mountains, but always without success.

"In the autumn of I886, Professor Sargent visited the mountainous region of North Carolina about the head waters of the Keowee River, with the object of rediscovering Magnolia cordata. At Hog Back, now called Sapphire, he was met by Mr. Frank Boynton, to whom he showed a leaf that he had gathered, and asked what it was. Mr. Boynton at first thought it was galax, but on looking at the leaf more closely said that he didn't know. The same evening a letter came from Dr. Gray in which he urged 
them to discover the original habitat of Shortia. Mr. Stiles, the editor of Garden and Forest, who was also present on this eventful evening, said in a joking way: 'That is Shortia you have in your hand.' This proved to be true. The leaf was Shortia. Professor Sargent had found it, just ninety-eight years after Michaux's discovery, probably near the same spot.

"About two weeks later, Professor Sargent, Mr. Boynton and his brother went to find the exact place of the plant's growth. They found it near Bear Camp Creek in a rather limited quantity, but still enough for them to carry away a box full of specimens for distribution. The following spring, Mr. Harbison started out in quest of it. He went beyond Bear Creek to the forks of the rivers and there saw it growing in great masses-acres, in fact, covered as thickly as clover fields. Wagon-loads were eventually taken away, and still there appeared to be no diminution in abundance. So the search for Shortia ended. Through the further efforts of Mr. Harbison, the plant is now well-known and a common one in the nursery catalogues, though in its wild state it grows at its finest and best under the shade of kalmias and rhododendrons."

Trans. Amer. Philosoph. Soc. Philadelphia, 1865.

Biog. Sketch of Charles Wilkins Short. S. D. Gross. Philadelphia, I865.

${ }^{2}$ Southern Wild Flowers and Trees. Alice Lounsberry. 


\section{JOHN TORREY \\ I 796 - I 873}

Torreya taxifolia-ARNOTT

The names of John Torrey and Asa Gray seem almost inseparable. In I830, Gray, a lad of twenty, came into New York bringing a packet of undetermined plants for Torrey to label, and from the dead plants sprang a vital lifelong friendship.

Torrey was born in New York on August I 5, I796, the son of a Revolutionary soldier, William Torrey, and Margaret Nichols. He had the ordinary public school education, and when he was fifteen two events occurred: his father was appointed Fiscal Agent of the State Prison at Greenwich, New York, and the family moved there; and John met Amos Eaton, ${ }^{1}$ a pioneer of instruction in natural science in America. Eaton taught the lad the structure of plants and encouraged him in his taste for mineralogy and chemistry, no mean preparation for the study of medicine in 1815 under Wright Post, and in the College of Physicians and Surgeons under Samuel

${ }^{2}$ Amos Eaton, botanist, I776-r842.

${ }^{2}$ Wright Post, surgeon, I766-1828. 
Mitchell ${ }^{8}$ and David Hosack." Being endowed with unusual natural gifts, he quickly forged ahead. He took his medical degree in 1818 with a thesis on Dysentery, and by I8I 7 had already presented to the Lyceum of Natural Historyof which he was one of the founders-his Catalogue of Plants growing within thirty miles of New York (1819), and enjoyed as correspondents such men as Sir James Edward Smith, Nuttall, ${ }^{8}$ and von Schweinitz.

About the time Elliott's Sketch of the Botany of South Carolina and Georgia was being published, Torrey conceived a similar systematic work on The Flora of the North and Middle Sections of the United States, and got out Volume I by the summer of 1824 . It showed the rare power of setting forth details in delicate separateness, yet as a comprehensive entirety.

In 1824 he was settled at the Military Academy at West Point with a bride, Elizabeth Robinson Shaw, and as Professor of Chemistry, Mineralogy and Geology. The Flora did not extend to a second volume, but ended in a pocket " Compendium" in I 826, for Torrey rightly foresaw that "the natural system was not longer to remain

\footnotetext{
${ }^{3}$ Samuel Latham Mitchell, surgeon, 1764-1831.

4 David Hosack, surgeon, 1769-1835.

' James Edward Smith, botanist, London, r759-1828.

- Thomas Nuttall, botanist-explorer, I784-1859.

${ }^{7}$ Lewis David von Schweinitz, D. D., I780-1834.
} 
an esoteric doctrine, but was destined to come into general use and change the character of botanical instruction." He himself was the first to apply it in any big work, and found his opportunity, when, in I 826, he wrote, in their natural orders, of the plants collected by Dr. Edwin James, botanist, in 1820 , to Major Long's Expedition to the Rocky Mountains. This was the earliest treatise of the kind written in America; and his energy in this direction being aglow, he set to work in 183 i on an American edition of Lindley's Introduction to the Natural System of Botany and added a catalogue of the North American genera on the same plan.

Not only Dr. Edwin James, but other botanical friends, were fond of entrusting their specimens, ideas or manuscript to his categorical and editorial care. Lewis von Schweinitz, when he went over to Europe, left his Monograph of the North American Species of the Genus Carex (1825) with Torrey to edit, but the " editing," from Torrey's idea of that office, meant practically rewriting and extension, a duty so faithfully done that von Schweinitz wanted it published under a joint authorship. Ten or twelve years later, Torrey's own elaborate Monograph of the other North American Cyperaceae appeared, with an appended revision of the Carices.

${ }^{3}$ John Lindley, botanist, I799-1865. 
One is, perforce, at this time a little sorry for our botanist. He wanted so much to embark on a grand undertaking-a general Flora of the United States; but leisure was scanty. He had taken a professorship of natural science at Princeton; and an appointment came just then as State Botanist to a geological survey of $\mathrm{New}$ York, which could hardly be refused. It meant much hard labor but in 1843 , after a great deal of discouragement, the result was his largest work: A Flora of the State of New York, in two large quarto volumes, with I6I plates.

But the other book was not forgotten. He asked his old pupil, Asa Gray, to become his associate. So the pupil stepped up nearer the master and put all his heart into the work, the two together making marvellous advances; and in July-October, I 838 , half the first volume was ready. The next year Gray went to Europe to study the sources and originals of earlier established species, and the latter half of the volume was out by June, I 840 . The second volume was completed in $\mathrm{I} 843$.

If we add to all this the Botanical Reports of the various land-exploring expeditions written from 1822 to 1858 , the amount of work done is seen to be astonishing, all being accomplished in the intervals of an overcrowded professional life. When in 1857 , he "exchanged a portion, and, a 
few years later, the whole, of his usual work to become United States Assayer," his time for writing became still more scanty, as the head of the treasury frequently asked his help in questions of counterfeit and other monetary problems.

Still, there were compensations, notably when, in 1865 , that same head sent him to California by way of the Isthmus, whereby his health became better and his herbarium more complete as he experienced the enjoyment of plucking, with his own hands, flowers he had named and described from dried specimens. The invaluable herbarium, along with a choice botanical library, he left to Columbia College.

A goodly number of the scientific societies of Europe gave him membership; and from Yale he had the honorary M. A., and from Amherst the LL. D. He was president of the American Association for the Advancement of Science, and twice president of the New York Lyceum of Natural History.

"Almost in his youth a genus was dedicated to him by his correspondent, Sprengel. This proved to be a Clerodendron, misunderstood. A second, proposed by Rafinesque, was founded on an artificial dismemberment of Cyperus. The ground, therefore, was clear, when, thirty or forty years ago, a new and remarkable evergreen tree was discovered in our own Southern states, 
which it was at once determined should bear Torrey's name. More recently a congener was found in the noble forests of California. Another species had already been recognized in Japan, and lately a fourth in the mountains of Northern China. All four of them have been introduced, and are greatly prized, as ornamental trees in Europe." So that, all around the world, Torreya taxifolia, T. Californica, T. nucifera, and $T$. grandis, should keep his memory as green as their own perpetual verdure. ${ }^{10}$

Dr. Gray, being sent away for a cough, made a journey to Apalachicola, Florida, going by Washington, Augusta and Tallahassee, of which journey and his successful search for Torreya he wrote a lively account for the American Agriculturist, republished in his Scientific Papers. Dr. W. P. Copeland, of Eufaula, Alabama, tells me that "The Chattahooche River, Florida, is said to be one of the two or three places in the world where the Torreya tree grows. It was discovered by Dr. Alvan Chapman, of Apalachicola, Florida, who lived at the mouth of the river where it empties into the Gulf of Mexico.

${ }^{9}$ Arnott's genus was the fourth Torreya, the three earlier ones not proving "good" genera . . . . but of course it is conceivable that any one of the three might at any time come to be regarded as "good." The name now accepted for Torreya taxifolia is Tumion taxifolium. Of course the name Torreya will undoubtedly cling to the plant permanently as a semi-popular one. (J. H. Barnhart.)

${ }^{10}$ Letters of Asa Gray, vol, ii. 


\section{SOME AMERICAN MEDICAL BOTANISTS}

Torrey investigated Dr. Chapmann's discovery and wrote it up. With the irony of fate, Chapmann did not have the honor of having the tree called after him.

"The common name given to the tree by the people is 'stinking cedar.' In 1877 I saw several posts in Florida on which a pigeon house was supported, the house said to have been built $b_{y}$ the Spaniards when they owned Florida. The posts were in a perfect state of preservation. Another name the tree has is ' gopher-wood tree.' The wood is said to last for centuries."

Torrey will be remembered by the students of the College of Physicians and Surgeons as an excellent teacher. No man had a better understanding of their character. Were they uproarious-he joined in their glee, and they soon lent an attentive ear. Were they stupid-he was patient and painstaking. Were they rude-he was always a gentleman, and at once commanded respect. He quietly pursued his course, giving the plain truth in a simple and comprehensive manner. The boys always had a good time in his room, for he relished a joke as much as any of them. In a serious and quiet manner he was closing a lecture with some remarks upon formic acids, when he was interrupted by the reception of a note from one of the students. His eye twinkled, and his benevolent face changed to a 
smile as he glanced at the question asked: "Is not formic acid an ant-acid?" $\mathrm{He}$ at once dismissed the class amid shouts of laughter, remarking that he was not prepared to give an immediate answer, but they should have the rest of the hour to themselves.

"His faith in the Holy Scriptures found a firm foundation in the study of nature. The God of the one was the God of the other. If there were difficulties, he knew, if not immediately, they would in time be reconciled. The more closely they were studied, the more positive would be the mutual confirmation."

The character of Torrey is best depicted in the influence he exercised over Asa Gray when the latter came to live with the Torrey family. Mrs. Torrey was also a woman of rare character and intellect, and devoutly religious. When Gray became one of the family, "the difference in the life, the contrast in the way of meeting trial and sorrow," as compared with his own family, "struck him forcibly, and the religious side of his nature was aroused and a serious interest awakened." "1

Torrey died on March Io, I873, at his house in Columbia College, and Gray, writing to De Candolle that summer, says:

\footnotetext{
${ }^{11}$ Letters of A sa Gray.
} 
I44 SOME AMERICAN MEDICAL BOTANISTS

"At a time when I was already overloaded, the death of dear Torrey has thrown some cares and extra work on me. I have to carry through the press a report of his upon the plants collected in west North America, in Wilkes' Expedition, which was drawn up, but never really finished, twelve years ago and was called for during Torrey's sickness, and to his annoyance, which I felt bound to relieve as well as I could."

Med. Reg. of the State of New York, 1873-1874, vol. xi.

John Torrey, by Asa Gray. Am. Jour. of Sci. and Arts, 1873, vol. v. Letters of Asa Gray. J. L. Gray. 



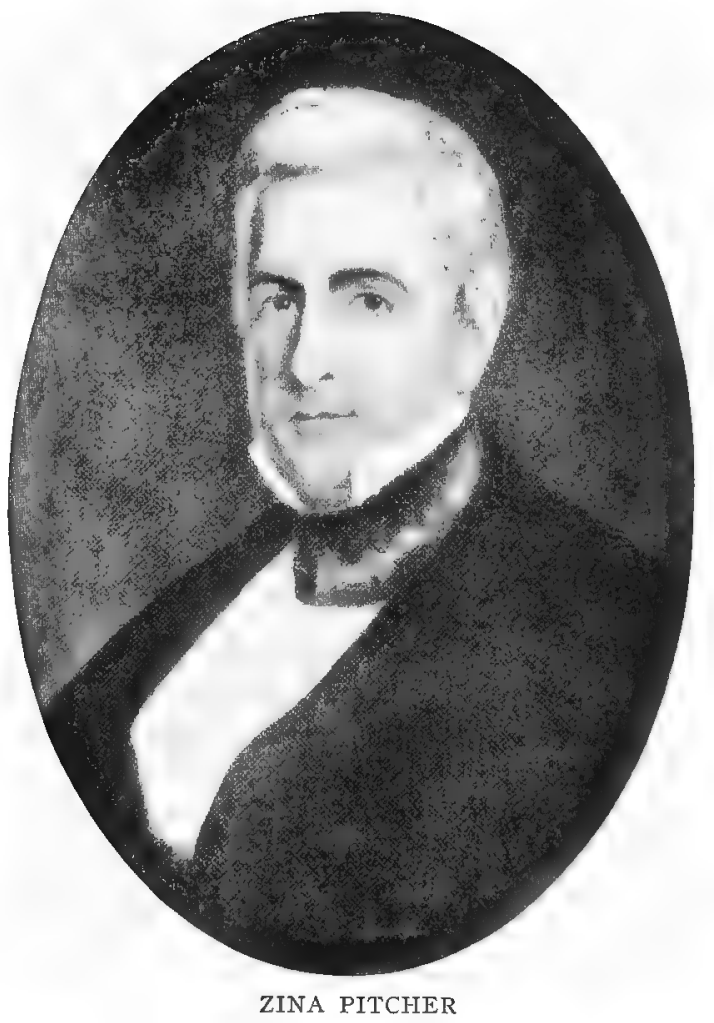

(From a family portrait) 


\section{ZINA PITCHER}

$$
\text { I797-I } 872
$$

\section{Carduus Pitcheri-TORREY}

It would seem almost reasonable to expect plants named for Zina Pitcher to be our familiar "pitcher " plants, but a thistle, a peanut, a clematis and a sandwort commemorate the botanist son of Nathaniel and Margaret Stevenson Pitcher, born April I2, 1797, on a farm in Washington County, New York. When five years old his father died, leaving the mother with four young sons and an unattractive farm. Being Scotch, she had learned the value of education, and she determined to provide the best possible for her children. The little boys went to the village school and helped on the farm, all eventually doing well-one of them becoming Acting Governor of New York. Zina "avoided the pleasures and excesses of his young associates," so I imagine him strolling in field and wood, noting everything, and making the burden of dull farm work a stepping-stone to his loving study of the natural wonders around him.

$\mathrm{He}$ began to study medicine at the age of twenty-one with private practitioners, and at Cas- 
I 46 SOME AMERICAN MEDICAL BOTANISTS

tleton Medical College, graduating in medicine from Middlebury College in 1822 . While studying he tutored in Latin, Greek and the natural sciences-the latter with Professor Eaton, of Van Rensselaer Polytechnic Institute, at Troy, New York. Soon after graduating, the Secretary of War, John C. Calhoun, sent him a commission as assistant surgeon in the United States army. The responsibility of this position rapidly developed his self-reliance, so that he was soon made full surgeon. During his fifteen years of army service he was stationed for the first eight years in the yet unbroken wilderness of the territory of Michigan.

Life at the frontier posts was not exactly luxurious. To read a list of the things deemed "necessaries" for army surgeons to-day makes one wonder how those of Pitcher's time ever survived. His friend, Dr. J. L. Whiting, summoned in 1823 to a sick garrison in Saginaw, gives a little glimpse of outpost life:

"I found the whole garrison sick, with one or two exceptions, and Dr. Zina Pitcher, the surgeon in charge, the sickest of the lot. He was completely broken up. He had some one hundred and twenty souls, old and young, sixty enlisted men, with officers, laundresses and children, under charge, and all of them sick but one, with one of the most abominably distressing fevers 
imaginable. He was all alone, one hundred miles from anywhere, with an appalling amount of work on hand, and no wonder he broke down. When I reached Saginaw he was being carried all over the garrison on a mattress, by men not well enough as yet to move about or lift anything, giving opinions and advice; and a dreadful sight he presented, I assure you."

But Pitcher managed to find time, not only to study medicine, but to study the flora around. He made friends with the Indians, wrote concerning their diseases and therapy, and embodied much of the knowledge so acquired in his monograph on Indian Medicine, which appeared in Schoolcraft's fourth volume on The Conditions and Prospects of the Indian Tribes, I854, a work preceded and followed by two Reports on the Epidemics of Ohio, Indiana and Michigan, George Mendenhall helping with the first two.

In I 828, the Michigan Historical Society was founded by General Cass, Schoolcraft and Pitcher. Here explorations, Indian lore and natural history formed the subjects for discussion, and Pitcher secured the sum of $\$ 970$ to purchase Audubon's splendid work on ornithology. It is easy to imagine the members gathering around to see the book, and the mutual congratulations upon its acquisition. 
In 1824 Pitcher married Ann Sheldon, of Kalamazoo, Michigan. They had a son (Nathaniel) and daughter (Rose) the mother died in 1864 . In 1867 he married Emily Backus, granddaughter of Col. Nathaniel Rochester, of Virginia, the founder of Rochester, New York, and, on the death of DeWitt Clinton, Acting Governor of New York. I do not know whether Nathaniel and Rose helped their father in his natural history work, as nothing much is told of his family life, the door just standing ajar when we read that " his home was at the service of the sick: he was known to have taken a stranger suffering from small-pox in to his home, and to both nurse and doctor him to recovery. Moreover, to him the Bible was a guide, a counsellor and an inspiration." Of his fruitful outdoor life his writings testify. In driving through the country he at once detected an unfamiliar plant or animal, secured a specimen and determined its place. While in Texas he collected many fossils and forwarded them to the Philadelphia Academy of Natural Sciences. Studies of these and allied collections were the basis of Dr. S. G. Morton's work, Cretaceous System of the United States. One of the specimens is known as Gryphaea Pitcheri. In Gray and Torrey's Flora of the $U$ nited States several new species are named after Pitcher in acknowledgment of his service to bot- 
any. Here are their names: Carduus Pitcheri, Torrey, a thistle found growing in the barren sand dunes on the shores of Lakes Michigan, Huron and Superior; Gaura Pitcheri, Torrey and Gray; Falcata Pitcheri, Torrey and Gray, "Pitcher's Hog Peanut," found by the Red River, Arkansas; Clematis Pitcheri, Torrey and Gray, found in the same place (this plant, by a revision of names, is now known as Clematis Simsii, Sweet; Arenaria patula, Michaux, "Pitcher's Sandwort" (Arenaria Pitcheri, Nuttall). (Torrey and Gray, in Flora of North America, vol. i.) "This genus is not now commonly recognized, though it is found in smaller Florae as a good genus." (J. H. Barnhart.)

His chief biographer, Dr. Frederick G. Novy, (physician and surgeon, I908), has gathered a list of his forty-one papers, which include:

1832. Penetrating $W$ ound of the Abdomen and Section of the Intestinal Canal Successfully Treated on the Plan of Ramdohr. (American Journal, Medical Sciences, vol. x.) (Under the conditions this was a remarkable piece of surgery.)

I853. Are Typhus and Typhoid Fevers Identical? (Peninsular Medical Journal, vol. i, second series.)

I853. Epilepsy Treated by Ligation of the Common Carotid Artery. (Peninsular Medical Journal, vol. i.) 
I 50 SOME AMERICAN MEDICAL BOTANISTS

I 855. On the Induction of Puerperal Fever by Inoculation. (Peninsular Medical Journal, vol. ii.)

I 855. Amputation in Utero. (Ibid., vol. iii.) I855. Malformation of the Heart. (Ibid., vol. iii.)

Pitcher was elected president of the American Medical Association, at its meeting in Detroit in 1856 ; he edited the Peninsular Medical Journal, I855-I858; he was president of the Old Territorial Medical Society for fourteen years; and president of the Michigan State Medical Society, I 855 - I 856 .

After a long, active life he began to feel rather tired. Even botanical fields are hard to the feet when life lingers in the shadows of seventy-five years; moreover, he had an inoperable bladder trouble which demanded heroic patience. The end came on April 5, I872.

History University Mich., Ann Arbor, University Press, I906.

Representative Men in Mich., 1878, vol. i.

Trans. Mich. State Med. Soc., I874.

Mich. Univ. Med. Jour., Ann Arbor, 1872, vol. iii.

Richmond and Louisville Med. Jour., Louisville, Ky., 1869, vol. vii, Trans. Amer. Med. Ass., vol. xxiii. 


\title{
CHARLES PICKERING
}

\author{
I $805-1878$ \\ Pickeringia Montana - NUTTALL
}

Charles Pickering, known to the scientific world as an anthropologist and botanist, was of good New England stock, being a grandson of Col. Timothy Pickering, a member of Washington's military family and of his first cabinet. $\mathrm{He}$ was born on Starucca Creek, Upper Susquehanna, Pennsylvania, on a grant of land owned by his grandfather. His father, Timothy Pickering, died when thirty, leaving Charles and his brother Edward to the care of their mother.

He left Harvard before graduation, but took his M. D. there in 1826 . In his earlier years he used to make botanical expeditions with one William Oakes; and when he settled in Philadel-

${ }^{1}$ Nuttall named two genera for Pickering. The first Pickeringia (P. paniculata), of the family Myrsinaceae, turned out to be a species of Ardisia. He therefore called another new genus (of leguminous plants) Pickeringia (type, $P$. montana), and this name is still in use anong certain botanists. However, I doubt if you will find the name adopted in any recent American publication; for the view now prevails that a name can be used only for the genus for which it was first proposed, and if it cannot be used for that (as Pickeringia cannot, because Ardisia is an older name) it cannot be used for any. The second Pickeringia is now Xylothamnia. (J. H. Barnhart.) 


\section{I52 SOME AMERICAN MEDICAL BOTANISTS}

phia in 1829 , he had a strong bent towards natural science, very soon being appointed one of the curators at the Academy of Natural Sciences, and during this time publishing a brief essay on The Geographical Distribution and Leading Characters of the United States Flora.

When the United States Exploring Expedition was organized in the autumn of 1838 to sail for the South Seas, Pickering was elected as the principal zoölogist, and the fame of that expedition rests chiefly on the work he then did with Professor Dana. Although Pickering retained the ichthyology, he went keenly into the geographical distribution of animals and plants; to the latter especially, as affected by the operations and movements of the races of man. A year after the expedition, and at his own expense, he visited Egypt, Arabia, Eastern Africa and Western and Northern India, publishing in 1848 his volume The Races of Men and their Geographical Distribution (vol. ix, Wilkes Exploring Expedition Report). In the fifteenth volume appeared his Geographical Distribution of Animals and Plants. He had no better luck than many a scientist; for, in the course of printing, Congressional appropriations stopped, and the publication of further Reports was abandoned. But, under privilege, he brought out in 1854 a small edition of the first part of his essay, and in 
I 876 a more bulky one $O n$ Plants and Animals in Their Wild State. These writings, and some contributions to scientific journals, notably to the Smithsonian Contributions to Knowledge, constituted his no mean help to the study of natural science; but he had been long and lovingly working on a book yet unfinished when he died, a book edited afterwards by his wife, Sarah S. Pickering, and appearing in 1879 , entitled Chronological History of Plants, or Man's Record of His Own Existence.

Professor Harshberger, from whom I have largely quoted, says he was singularly retiring and reticent, dry in ordinary intercourse, but to those who knew him well, communicative and genial.

The Botanists of Philadelphia. J. W. Harshberger. 1889.

Proc. Acad. Nat. Sc., Phila., 1878. W. S. W. Ruschenberger. 


\section{JOHN LEONARD RIDDELL}

$$
\text { I } 807-\text { I } 865
$$

\section{Riddellia tagetina-NUTTALL}

John Leonard Riddell, physician, author and inventor, was born in Leyden, Massachusetts, in I 807 , of fine Scotch-Irish ancestry which could be traced back to the eighth century.

He held his degrees of A. B. and A. M. from the Van Rensselaer School of Troy, New York, and began his career as a lecturer on scientific subjects. In $\mathrm{i} 835$ he was made adjunct professor of chemistry and botany in the Cincinnati Medical College, from which he received his M. D.; and during this year, also, he published $A S y n \circ p$ sis of the Flora of the Western States, the pioneer botany of that section of the country. In 1836 he became professor of chemistry in the Medical College of Louisiana, a distinction which he enjoyed until his death in 1865 .

His catalogue of Louisiana plants secures to him the discovery of several new, or unobserved species, one genus being called for him Riddellia (Riddellia tagetina, Nuttall).

Professor Barnhart tells me that:

"The manuscript, which was published in the New Orleans Medical and Surgical Journal, vol. 


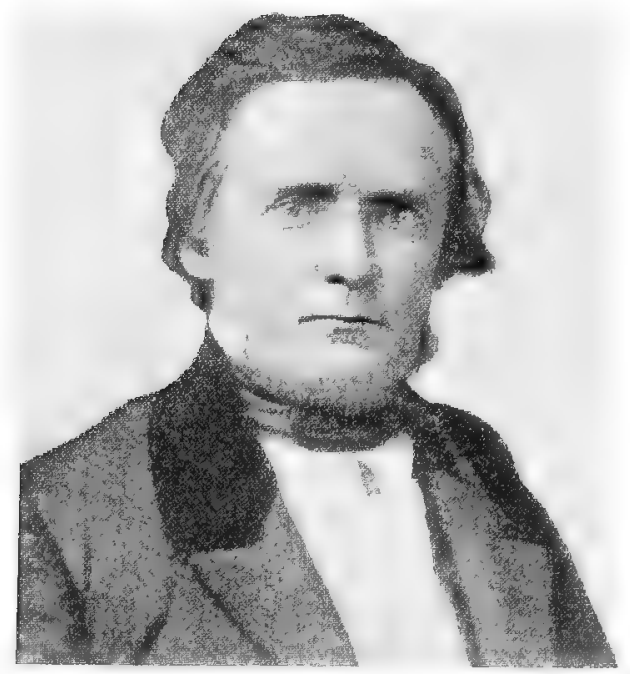

JOHN L. RIDDELL 

viii, pp. $743-764$, May, I 852 , is prefaced by this paragraph:

" The following systematic list, embodying the results of a great many years of observation, by Dr. Josiah Hale, by the late Prof. W. M. Carpenter, and by the author (Riddell), has been abridged from a manuscript work contributed by the author, in $185 \mathrm{I}$, to the Smithsonian Institution. The manuscript work alluded to is entitled "Plants of Louisiana." It comprises the technical and the vulgar names of the flowering and filicoid species of plants, well ascertained as growing within the limits of the State of Louisiana (nearly all of which are represented by specimens in the author's herbarium) -with special localities, times of flowering, and full descriptions of the new species. The Cyperaceae and Gramineae, specially contributed by Dr. Hale, are not included in the present abridgement.'

"There is another reference to the manuscript in the Botanical Gazette, vol. viii, pp. 270 and 27 I, August, I883, which gives no further data regarding the manuscript, but states that 'His herbarium ... . is said to have been very large and excellently arranged.'

"There is a further reference to his herbarium in the Ohio Naturalist, vol. i, p. 33, January, I9or, which states that scarcely any of his specimens seem now to be in existence, though he pre- 


\section{I56 SOME AMERICAN MEDICAL BOTANISTS}

pared sets for sale and accumulated a large herbarium."

In 1838 the President of the United States appointed Dr. Riddell melter and refiner for $\mathrm{New}$ Orleans, in recognition of the creditable work performed in a scientific exploration conducted in Texas; he held this office until I 849 . In I 844 he was one of a commission recommended by the governor and legislature to devise a means for protecting New Orleans from overflow, and about this period he became devoted to microscopy and invented the binocular microscope. (Ency. Brit., vol. xvi, ninth edition.)

$\mathrm{He}$ it was who advocated the organic nature of miasm and contagion as early as 1836 , and later made extensive investigations concerning the microscopic characteristics of the blood in cholera and yellow fever.

Daniel Drake and his followers. Otto Juettner.

N. Orleans Med. \& Surg. Jour., vol. xix, I866-r867.

Personal Communications. 


\title{
GEORGE ENGELMANN
}

\author{
I 809-1 884
}

\section{Engelmannia pinnatifida-TORREY}

The sponsorial claimant of Engelmannia is first seen at Frankfurt-on-the-Main, the eldest of thirteen children (his birthday February 2, I 809), and in student days at Heidelberg University particularly happy because Agassiz, Karl Schimper ${ }^{2}$ and Alexander Braun ${ }^{2}$ were also there. The next glimpse shows him graduating as a doctor at Würzburg and reading a thesis on De Antholysi Prodromus, in good Latin, treating of morphological monstrosities in plants and their metamorphoses. Gœthe noticed and approved it and offered to place his own notes and sketches in his hands, but death intervened and carried off the poet. "This essay," says Dr. Boislinière," "was soon followed by a monograph, also in Latin, on the habits of a little creeper he had found on a hazel bush, and it delighted scientists on account of the minuteness and perfection of the observations. He always investigated systematically and accepted in science nothing for granted until it had passed

${ }^{1}$ Karl F. Schimper, botanist, $1803-1867$.

${ }^{2}$ Alexander Braun, botanist, I805-1877.

${ }^{3}$ St. Louis Med. \& Sur. Jour., 1893. 
I58 SOME AMERICAN MEDICAL BOTANISTS

through the searching crucible of his analogical mind."

Before coming to America he spent a year in Paris studying medicine and obstetrics. Cholera was raging most of the time, but he had Agassiz and Braun with him, and much useful scientific investigation was made.

Meanwhile, in 1832 , glowing accounts of the possibilities in western America had reached two of his uncles in Dresden, and these resolved to make land investments in the Mississippi Valley. Some relations were already settled in Illinois; why not send nephew George to investigate? He could botanize and perhaps found a practice. So it was arranged, and the student from crowded Paris " made long and lonely journeys through southern Illinois, Missouri and Arkansas." In his excursions through the wilds of Arkansas he stopped one night at a farmer's rude cabin, and while cleaning the large knife which he used to dig out plants and roots, the farmer, watching him closely, and thinking that Engelmann had some murderous design, stepped forward and said, "Look ye here, stranger, let us swap knives " -at the same time brandishing a vicious-looking "Arkansas toothpick." Engelmann was at some trouble to convince this backwoodsman that he used his knife only to dig out roots.

$\mathrm{He}$ used to make notes on, and sketch the plants en route, and must have had that rara avis, 
an intelligent secretary, for the collected notes were all found and filled sixty file books in the Missouri Botanical Museum after his death.

"His method of working was to take a single group of plants and work it over systematically, so far as was in his power. His treatment of the genus cuscuta ${ }^{*}$ increased the number of species from one to fourteen, without going west of the Mississippi Valley. Seventeen years later .... he published a systematic arrangement, giving twenty-seven species, besides varieties."

After several excursions he decided to settle in St. Louis, then a town of only Io,ooo inhabitants. It required some courage; for he was not rich, and even had to sell his guns and pistols to help pay the rent. Fortunately, St. Louis was a growing city, and it was soon discovered there was no one more skillful in ushering young citizens into the world than Dr. Engelmann; he was the first there to use the obstetric forceps, though the local accouchers were strongly against the innovation.

Four years of patient, hard work in St. Louis permitted a visit home to "the happy fatherland " to marry Dora Horstman. She had been waiting ten years and was ready to travel to faraway Missouri with her husband, who, with a somewhat heavy practice in town, a love of bot-

- A genus of parasitic plants of the convolvulus family. 
any drawing him to the country, and a strong scientific bent, especially towards meteorology, could not have had much time for the young wife; yet, when she died in 1879 , his friend, Dr. Boislinière says: "Engelmann was inconsolable and in spite of attempted consolation by his friends, of whom I had the honor to be one, and occasional visits to the Rocky Mountains and Colorado, he gradually succumbed to the intensity of his sorrow."

During the latter part of his life he travelled over the mountains of North Carolina and Tennessee, the Lake Superior region and the Colorado plains to study in situ the Cacti, Coniferae and other groups. The year of his wife's death he made a long journey through the Pacific States to see, in full dress and beauty, many plants hitherto known as half-clothed exiles, or viewed lying stiff and stark in an herbarium. He published in America his masterpiece, The Monography of North American Cuscutinae. This was republished by botanical periodicals in England and Germany; also in America, in I842, by the American Journal of Science. His descriptions of the Cactaceae of the Pacific Railroad Survey followed; and several years later came his most renowned work on the Cactaceae of the boundary, which forms a highly interesting portion of Emory's Report of the United States and Mexican Boundary Survey, I858. He went over to 
Europe in 1856 and stayed there two years, directing the engraving of the plates for this work.

Many other papers on botany were also published by him at different times: The Yucca, The Agave, The Conifera, The American Oaks, etc. His publications on the North American vines deserve particular mention for their importance to the grape-growers of this country and of Europe. In 1856 he originated the St. Louis Academy of Science, of which he was first president.

His name has been given to a monotypic genus of plants, Engelmannia, by Torrey and Gray. There are many letters to Engelmann in The Letters of Asa Gray, and in one ( $184 \mathrm{I}$ ) he refers to a species named after his friend: "Eupatorium Engelmannianum, sp. nov. Am. Bor., semina misit Engelmann. Can this be it, think you? If so, pray help me to it, and to anything else you can, as I mean to give addenda et corrigenda to the Compositae at the end of the order if I ever get through this formidable job. No wonder seven years' labor at them ruined De Candolle's health. You know he is dead?"

There is another letter from the cheery Gray worth quoting. Writing to Engelmann on July 4, I 877, he says:

"Dear old E.:

"Never mind if you are seventy; Hooker is sixty, and I am between, and we are lively yet. 


\section{I62 SOME AMERICAN MEDICAL BOTANISTS}

"Perhaps we young fellows may knock about rather faster than you like, wanting to do much in a little time. But then, you need not do so much in Colorado as we. Take the easy part . . . I shall be sorry if you fail us.

"We must twine in Cuscuta as we twine in the rest of the book. For real accuracy we must finally come to the terms I propose, entropic and antitropic."

This was written two years before Mrs. Engelmann died and Engelmann's health failed. A journey was taken to Germany in 1883 , and he picked up again, was even able to work there; but after more sickness he came back, was again helped by the voyage over, and again did some work, but increasing infirmities gradually lessened his powers until his death on February 4, I 884 .

A list of his botanical papers has been published by Prof. C. S. Sargent in Coulter's Botanical Gazette for May, I884, who enumerates one hundred and twelve entries, and also counts thirty-eight scientific societies of which Dr. Engelmann was a member.

Am. Jour. of Sci., New Haven, 1884, 3 s., vol. xxviii. (A. Gray.) Pop. Sci. Mon., New York, 1886, vol, xxix.

St. Louis Med. and Surg. Jour., 1893, vol. lxv. (L. C. Boislinière.) Science, Cambridge, 1884, vol. iii.

Weekly Med. Rev., Chicago, 1884, vol. ix.

A Biographical History of Botany in St. Louis, Mo. Dr. Perley Spaulding, rgog. 


\title{
ALVAN WENTWORTH CHAPMAN
}

\author{
I 809- I 899
}

Chapmannia Floridana-TORREY AND GRAY

I managed with great difficulty to secure a copy of the Flora of the Southern United States (1860), by Alvan W. Chapman, of Apalachicola, Florida, but I had not much success in tracing the life of the author. He was born in Southampton, Massachusetts, graduated at Amherst College in 1830 , and began practice in Apalachicola in 1847 . His Flora was preceded by $A$ List of Plants Growing in the Vicinity of Quincy, Florida, I845, while the Flora ran through two extra editions, I882 and I896, and became the leading authority for the Southern States. Gray and Torrey named one of the papilionaceae Chapmannia Floridana after him; and Gray, writing in his Journal, I839, says, Chapmannia exists in Bartram's old collection here, which you saw at the British Museum."

Chapman's first and larger herbarium went to Columbia University, and a later collection with most of his library, is owned in Biltmore, North Carolina, by the Vanderbilt estate. 
I64 SOME AMERICAN MEDICAL BOTANISTS

The people of Apalachicola hope some day to erect a suitable monument over Chapman in their city graveyard; but the perishable flower is more enduring, and, if the ghostly sponsor, with unimpressioning feet, should tread again these earthly fields, his spirit will be sufficiently gratified to find his work marked "rare " in the antiquarian's catalogue. 



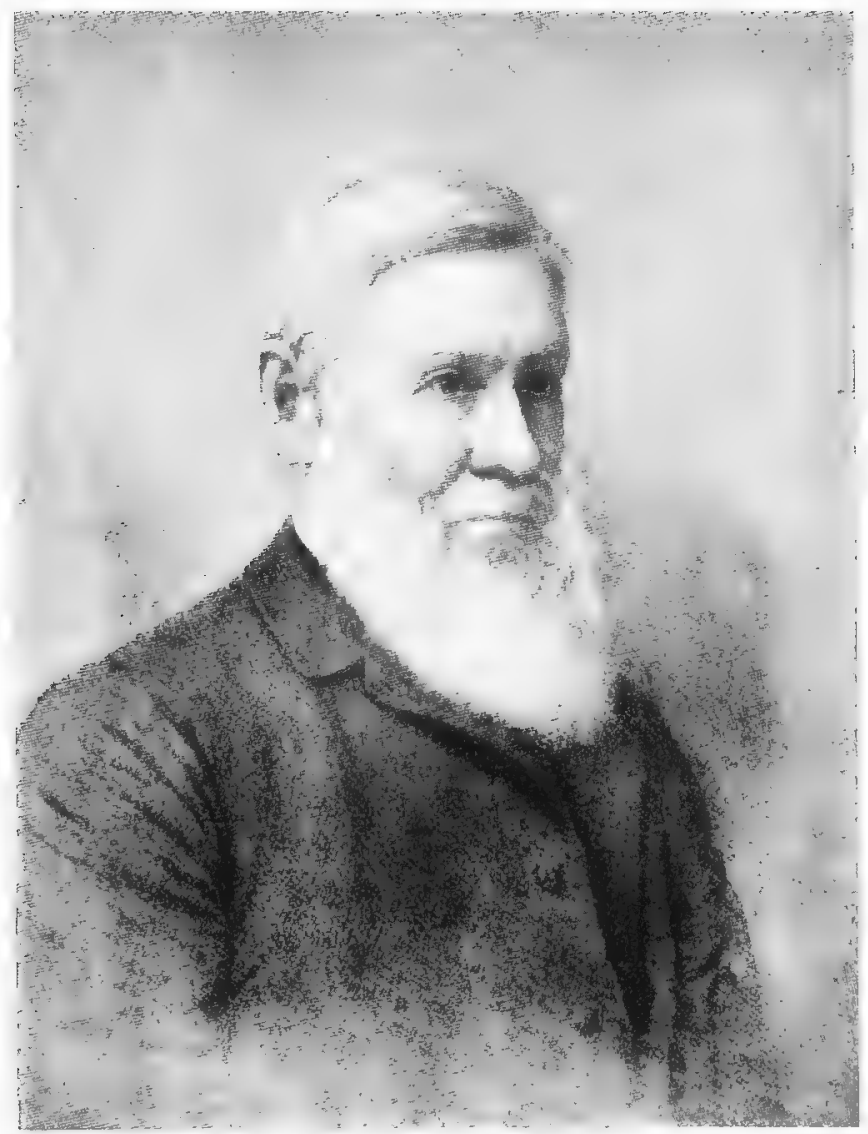

ASA GRAY

(From an engraving by Gustav Kruell, 1890) 


\section{ASA GRAY \\ I $810-1888$}

\section{Lilium Grayii-HOOKER AND ARNOTT}

Could our great men come into the world so labelled, expectant relations would surely treasure up for posterity all those evidences of genius or the curious lack of it in childhood and youth which so arouse our wonder in later years, when they have passed within the hall of fame. But the first generation dies, and the son who is leader in the next has too great modesty to pour out for an expectant, eager posterity all of his early career. So, of Asa Gray, there survives only a group of uncertain reminiscent planks with which to bridge the gaps in an interesting life - a life which started in the household of a tanner in Sauquoit, Oneida County, New York, on the I 8 th of November, I8Io, the parents being Moses and Roxana Gray, the father hailing originally from Londonderry, Ireland, and the mother from Kent, England.

Not long after Asa's birth they moved to Paris, Furnace Hollow, Sauquoit, and set up a tannery and a shoe shop. "Of the tannery," says Gray, 
"I retain some vivid recollections, especially those connected with the first use to which I was put, the driving round the ring of the old horse which turned the bark mill, and the supplying the said mill with its grist of bark-a lonely and monotonous occupation." A young aunt of ten escorted him, when three, to the village school, where his genius seemed to lie in spelling, and his chief occupation in "my omnivorous reading. .... I was a reader almost from my cradle. ... There was a little subscription library at Sauquoit, the stockholders of which met four times a year and distributed the books by auction to the highest bidder, to have and to hold for three months. One Sunday afternoon ... . I went into the public room of one of the two village inns, where half a dozen of the villagers were assembled and one was reading aloud Quentin Durward.... this was my first introduction to the Waverley novels." The coming of seven more little Grays somewhat depreciated the increased family prosperity, but Asa, after some years at academies, was sent, without any college education, to the Fairfield Medical College, where he graduated in medicine in $183 \mathrm{I}$, with a thesis on Gastritis. The data for this maiden medical lucubration may well have been generated in the youthful stomach, sorely tried by being "boarded out" by an uncle who sold 
stoves and let some of the buyers feed Asa and a fellow-student in lieu of paying for the goods. "One woman fed us so much on boiled salt cod, not always of the freshest, that the sight of that dish still calls up ancient memories not altogether agreeable."

The spring and summer of 1827 were passed with Dr. Priest of Sauquoit, and in the course of the winter at Fairfield he bought Eaton's Manual of Botany, "pored over its pages and waited for spring. . . . I I sailed forth one April day into the bare woods, found an early specimen of a plant in flower peeping through dead leaves, brought it home, and, with Eaton's Manual, without much difficulty I ran it down to its nameClaytonia Virginica. (It was really $C$. Caroliniana, but the two were not distinguished in that book.) I was well pleased, and went on collecting and examining all the flowers I could lay hands on.... I began an herbarium of shockingly bad specimens."

"In addition to Dr. Hadley's summer course of lectures on chemistry, Dr. Lewis C. Beck used to come and deliver a short course of lectures on botany. He gave this up the year in which I received my $M$. D. ; so Professor Hadley invited me to come and give the course instead."

About two years after, Professor Torrey engaged Gray to go and collect plants in the pine 
barrens of New Jersey, he to take the half of the collection and pay expenses in the field. While at Quaker Bridge he met a "fine-looking man who came down in a chaise looking after some particular insect"; this was Major Le Conte, long time a resident of Philadelphia and active member of the noted Academy of Natural Sciences, whom I also knew for many years.

The following year-Gray is not quite sure of the date-he got a furlough from Bartlett's School at Utica, where he was teaching botany, and became assistant to Torrey during his course of chemical lectures in the Medical College of New York, living in his house in the herbarium and receiving $\$ 80$ as pay.

The first century of his North American Gramineae and Cyperaceae came out in the winter of 1834 . But rather a disappointing time came between this and the next century, in I 835 . He had thrown up the appointment at Bartlett's School, and now Torrey-the Medical College being in a bad way-found he could no longer have an assistant; but Gray determined to go to New York and help him. Staying with Torrey was really a fine part of Gray's education; for the scientist was also a devout Christian and, with his religious, kindly wife, criticised and amended the young man's manners, tastes and habits, rous- 
ing the deeper side of his nature and creating a lifelong faith.

In the spring of 1835 he went home for a while, armed with such books as De Candolle's Organographia and Théorie Elementaire, which he "devoured like novels." Here, too, he partly wrote his Elements of Botany. Returning to New York and taking cheap lodgings, he found "the prospect for daily bread rather dark"; but Carvill, of New York City, agreed to take his Elements and give him \$150. His friend, John Carey, helped read the proofs, over which there was "warm and noisy discussion" as they worked together at his boarding-house. Brighter times came when the New York Lyceum of Natural History completed its hall and appointed Gray Curator, on very small pay, but with time to write. "There I wrote my papers Remarks on the Structure and Affinities of the Ceratophyllaceae, 1837 , not a very wise production, and some of the observations are incorrect; also the better paper, really rather good, $\mathrm{Mel}$ anthacearum Americae Septentrionalis Revisio, I 837."

Torrey had planned and was working very slowly on his Flora of North America when Gray came offering his leisure to work up some

${ }^{1}$ John Carey, botanist, - I880, wrote chapters on "Willows" and "Sedges" in the Manual of Botany. 


\section{I7O SOME AMERICAN MEDICAL BOTANISTS}

of the earlier orders, manifesting the catholicity of spirit of a real genius. The great desideratum was to get a big and useful work through, and Torrey welcomed the help, though he nearly lost it, for Gray had been appointed in 1836 botanist to a South Pacific Exploration. However, there were so many "alarums and excursions," such endless delays, that the explorers did not sail until 1838 , and meanwhile Gray had accepted the professorship of Botany in the University of Michigan and continued helping Torrey, who, quick to appreciate Gray's value, asked him to be joint author. The first part was issued in July, the second in October, 1838 , at their joint expense, Gray paying his with the salary received while waiting orders for the South Pacific voyage. That same year inclination and circumstances jumped together. It was quite clear that he could not "profess" anything in a University which had no building, and equally clear that not enough was known of the original sources of information to work up the North American flora properly. Michigan University wanted books for a general library. Torrey and Gray equally wanted much information from Europe. Michigan behaved generously and gave Gray a year's leave, with $\$ \mathrm{I}, 500$ as salary and $\$ 5$,000 to spend on books in Europe. 
Gray made the most of his year; his letters home are crowded with the joys of visits to old friends, the making of new ones and the happy times spent in botanic gardens. These epistlesmost of them-have been gathered in the Letters of Asa Gray and present delightful reading for all true botanists.

The head of the Putnam firm-George Putnam-then living in London, guided him in obtaining the books his friends recommended for the University of Michigan; and it is easy to imagine Gray walking around with a notebook, jotting down titles, and also his pleasure in going over the books on his return, as he dilated on their special merits, lingering a while, before he put one down, as he recalled the man or circumstances which had led to that particular purchase.

The authorities of Michigan University were quite willing to extend his furlough (without pay) ; so Gray "took sharp hold of the Flora of North America, and in June, I840, put out parts 3 and 4 of vol. i, then went at the Compositae." But the work was interrupted for a while, because he went with John Carey on a botanical trip up the Valley of Virginia to the mountains of North Carolina.

Sometime in April, I84I, President Quincy, of Harvard University, wrote offering him the Fisher Professorship of Natural History, with 


\section{I72 SOME AMERICAN MEDICAL BOTANISTS}

$\$ \mathrm{I}, 500$ annually. As the chief subject was to be botany and the care of the Botanical Garden, some seven acres, he accepted the offer and tells Torrey that he has "the privilege of spending $\$$ IOo in botanical illustrations, to be the property of the college," and asks his advice, adding: "Though greatly behind-hand I must get Compositae all done this month. I am deep among Thistles, which are thorny, though I see they are satisfactionable."

He was very nervous about his first lecture. $\mathrm{He}$ " made a few remarks without stammering a bit." Once, at the end of the hour, he offered another hour with the option of leaving, but they all remained. Another time he caught "one of the fellows throwing his cap to a companion or playing some trick. You know I can scold; so I gave him about half a dozen words which made him open his eyes wide, and I do not think that he, nor any of that division, will venture upon anything of the kind very soon."

Gray also takes a Sunday School class "of eight or nine very intelligent misses from sixteen to twelve," a variation after a week with rough students. He did a good deal in the way of planning lectures when away in Virginia and Carolina in the fall of 1843 . Dr. George Engelmann hears from him that he is also "preparing for a terrible course of public lectures, so that I cannot 
work at the Flora until spring. But I will find time to study and revise any sets of Lindheimer's, Geyer's and Lüder's plants you send. . . . . As to my paper on Ceratophyllaceae, I have long since wished it unpublished, as it contains mistaken views."

His life at this time was very full, and friends laughingly recall his alertness, mental and physical. "In the street he was usually on a half-run. .... When travelling by coach and climbing a hill, he would sometimes alarm his fellowtravellers by suddenly disappearing through a window, in his eagerness to secure some plant he had spied. He was quick and impetuous in temper, but his prevailing spirit was one of apparently inexhaustible good nature." Prof. J. K. Hosmer says: "On an autumn day, in the early fifties, as I loitered in the greenhouse of the Botanic Garden at Cambridge, a lithe, bareheaded man, in rough brown attire, quickly stepped in from the flower-beds outside. He was in his fullest vigor, his hair smooth, his dark eyes full of animation. It was a noticeably vivid and alert personality; and as he tossed onto a working-table a heavy sheaf of long-stemmed plants, wet from a recent shower, and bent over them in sharp scrutiny, I became aware I was in the presence of Asa Gray, the first of American botanists. He had come as a boy from a remote 
I74 SOME AMERICAN MEDICAL BOTANISTS

rural district; and with few advantages, following the bent of a marked scientific genius, he had won for himself before reaching middle life a leading place. I was soon to know him better, for it was my fortunate lot to be one in the crowd of juniors which for a term lined up before him once a week or so in Holden Chapel."

He was happy, too, in his work, though hampered for want of funds for the garden and his books. He found it difficult, in I847, to make an arrangement "for the publication of the Illustrated Genera and arranged to pay the expenses of the first volume, but it led him heavily into debt." The first edition of his Manual appeared in 1848 , " a model of clear arrangement and masterly description." Associated with the Manual were the various text-books, from How Plants Grow, I 858, to the Structural Botany, I 879. One of his best papers was on The Relation of the Japanese Flora to that of North America.

Gray, with his wife, sailed for England on June I I, I 850 . Though it is tempting to dwell on all his journeys, his visits and enthusiastic work while abroad, the boundaries of a short biography would soon be passed.

How much he did in the way of collecting and writing can only be estimated by those who knew how he kept in constant correspondence with old pupils and scientists. Those who are curious as 
to that between Gray and Darwin will find it all in Gray's Darwiniana, 1876 , and will note that he, while accepting Darwin's theory, was a firm theist. He tells Darwin ( 187 I), in thanking him for his Descent of Man:

"I have not had time to read any of it, so keep it well out of sight, not caring to look just yet at any of the pages which you think likely to 'aggravate' me. . . . Y You have such a way of putting things, and you write in such a captivating way. One can only say: 'Almost thou persuadest me to have been a hairy quadruped of arboreal habits, furnished with a tail and pointed ears,' etc."

In 1872 he resigned his professorship at Harvard, asking still to be Curator of the Herbarium. This resignation left him free for excursions, for writing, and for lecturing on outside topics, notably two on Natural Science and Religion before the Yale Theological School in I 880; but that same year he was off to Europe, and again in 1887 , but always writing and planning new work, the results of which may be seen in the complete list published in the Letters of Asa Gray.

On the morning of his $75^{\text {th }}$ birthday came a wonderful silver vase from $\mathrm{I} 8 \mathrm{o}$ of his American botanical friends. On it were represented many of the North American flora, and Gray had great 


\section{I76 SOME AMERICAN MEDICAL BOTANISTS}

delight in recognizing them. By this year he had also many floral namesakes, and a mountain peak in California called after him by Dr. Parry. Three different genera were named for him: Grayia, Hook. and Arn., in I $84 \mathrm{I}$, a genus of the Chenopodiaceae, Asagraea, Lind., in 1839 , and Asagraea, Baill., i 870 . The two latter are not now in good standing, having been reduced.

Among the species are: Notholaena Grayi, Poa Grayana, Cyperus Grayi, Rhynchospora Grayi, Lilium Grayi, Oreobroma Grayi, Silene Grayi, Anemone Grayi, Ranunculus Grayi, Saxifraga Grayana, Potentilla Grayi, and many others. These are all North American plants, but others are not limited to North America.

There was scarcely a society of note which did not claim Gray as active or honorary member or give him honors. He held the Edinburgh LL. D., the Oxford D. C. L., the Harvard M. A. and LL. D.

After his return from Europe in 1887, he meant to write some account of the old botanists he had seen in his earliest visits; he "also took up work on the Vitaceae, for the Flora."

Thanksgiving Day came and he went into Boston to the family dinner, though a slight cold and fever troubled him. On Sunday, though poorly, he came downstairs and wrote a long letter to Dr. Britton concerning the naming of 
Conioselium Canadense, but the next morning there was slight paralysis of the right arm and tongue. He lingered patiently, in much weakness, until the 3 oth of January, I 888 , when he gradually sank and quietly passed away. A simple stone in Mount Auburn records his emigration. The Gray Herbarium at Harvard guards his best earthly treasures, and all men are heritors of the knowledge which he garnered for America.

Letters of Asa Gray.

American Acad. of Arts and Sciences, Cambridge, 1888.

Proc. Royal Society of London, 1889.

Nat. Academy of Medicine, Washington, 1895.

A Notice of Asa Gray. W. Deane. 1888. 


\title{
ARTHUR WELLESLEY SAXE
}

\author{
I 820-I 89 I
}

\section{Rumex Saxei-KELLOGG}

The first real glimpse of Saxe is as a student painting pictures, chiefly portraits, to pay his fees at Castleton Medical College, where he graduated in medicine.

He was born at Plattsburg, New York, October 20,1820 , and had only a common school education, though he also took painting lessons with a good artist.

In May, I 850 , he went to California, and was in the mines until 1852 ; but two years afterwards he is heard of as a resident doctor in Santa Clara County, California, where he remained until his death at Pasa Robles, in May, I89r.

That he was president of the State Medical Society and of the State Horticultural Society and owned "one of the largest collections of roses and rare bulbs in the state "gives a fairly good picture of the man at home, while accounts of some botanical excursions through California and to the Sandwich Islands show him to have been an energetic traveller and a real amateur in the botanical world. He did good work as a doctor, was a skillful surgeon, and was reputed to 


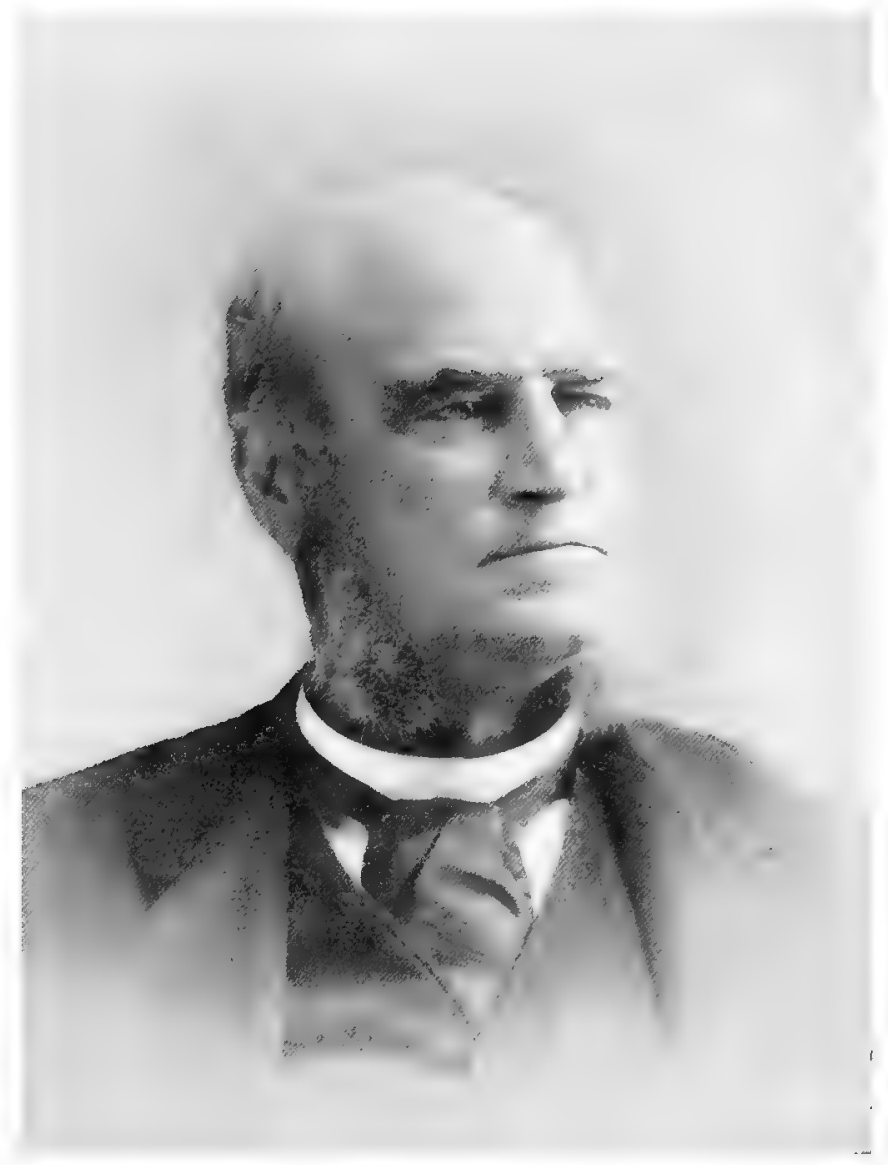

A. W. SAXE 

be very clever in the use of obstetric forceps and difficult cases of catheterization, two important accomplishments in his day. His report on leprosy-the result of study in the Sandwich Isleswas read before the State Medical Society of California in 1880 .

It was in conjunction with Dr. Kellogg, who at one time had charge of the California Academy of Sciences, at San Francisco, that he made his most extensive study of the flowers and plants of California. Two plants were named after him: Rumex Saxei, Kellogg, mentioned in the Pacific Rural Press, June 7, 1879, and Clarkea (eucharidim) Saxeana, or Green Petonia, in 1887. After his death, a tree in the park at Santa Clara was called the "Saxe Tree," in memory of him.

When Saxe went to the Sandwich Isles, he became a warm friend of the late King Kalakau and was always his guest at court. On one of his visits he painted a clever picture of the burning crater of Mauna Loa, doing most of the work at midnight, at which time the flaming crater presented the finest appearance.

Much of his work was destroyed in the San Francisco fire; but his brother, Dr. Frederick Saxe, of Oakland, California, has a small book of water-color sketches of flowers and plants made at odd moments.

Personal communication from Dr. Frederick Saxe. 


\section{CHARLES CHRISTOPHER PARRY I 823-1890}

\section{Lilium Parryi-WATSON}

In the year I 823 one of the many Englishborn American botanists came-a little lad of ten-from Gloucester, England, to Washington County, New York. "Here," says his biographer, Dr. C. H. Preston, "his boyhood was passed"-how passed, and when his taste for botany developed, we want to know but are not told. He entered Union College, at Schenectady, and graduated with honors, beginning the study of medical botany in his undergraduate years, and subsequently receiving his medical degree from Columbia College.

Coming west to Davenport in the fall of I 846 , he began practice, but soon discovered that his natural tastes ranged far from disease and drew him to the treasures of wood and field.

Thenceforward his life story is interwoven with that of three of his spiritual kindred, Torrey, Gray and George Engelmann, and presents, apart from the scientific side, a wonderful record of travel and toil.

In the summer of 1847 , he accompanied a United States surveying party, under Lieut. J. 


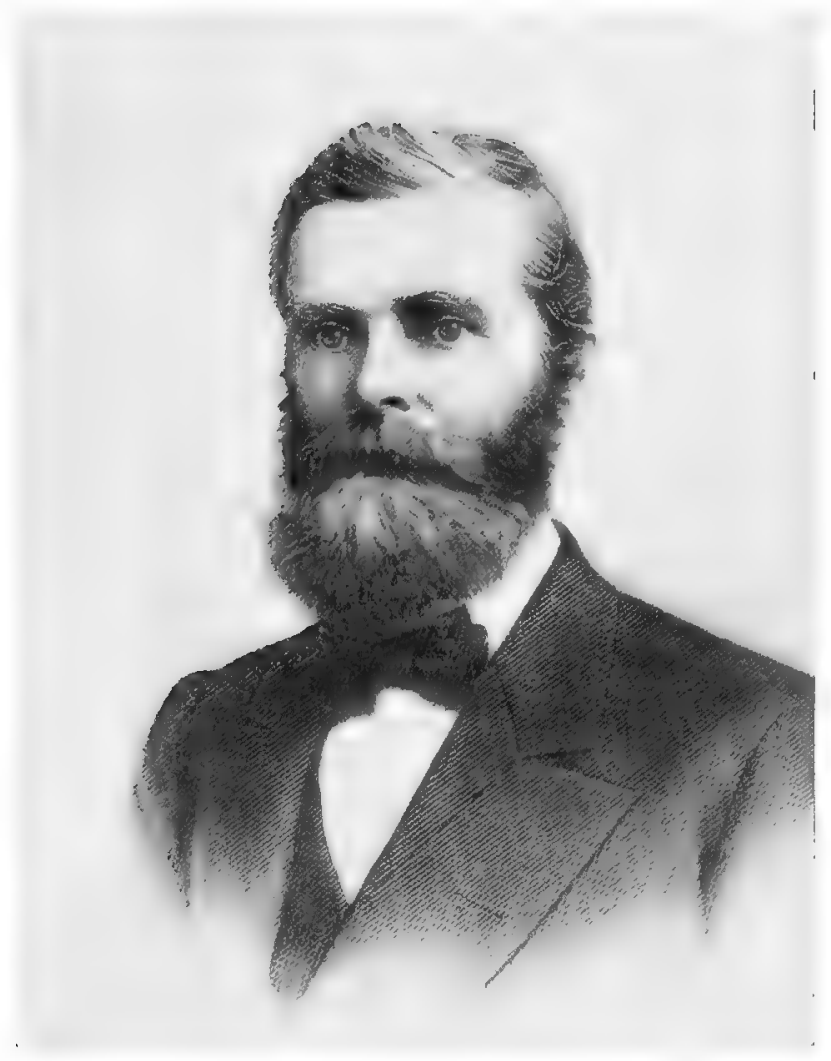

CHARLES CHRISTOPHER PARRY

(From a picture at the Davenport Academy of Science, Iowa) 

Morehead, on an excursion into Central Iowa, in the vicinity of the present state capital. From this time on (except for a short period while connected with the Mexican Boundary Survey, discharging the duties of assistant surgeon), the physician was merged in the naturalist. He was almost continuously in the field, collecting; but Davenport, Iowa, remained his nominal home. Here, in 1853 , he married Sarah M. Dalzell, who died five years later and left him with an only child-a daughter, who died at an early age.

In 1859 he married Mrs. E. R. Preston, of Westford, Connecticut, who for more than thirty years shared his work.

In the Proceedings of the Davenport Academy of Science, vol. ii, Parry gives a chronological account of his work up to 1878 . The greater part of his time was spent in observing and collecting along the St. Peters and up the St. Croix. to Monterey, in the mountains of Colorado and California, as he was interested in a special study of the Alpine flora of North America. Then this energetic man set out with a Pacific Railroad Survey through New Mexico, ending in Mexico about San Luis Potosi and Monterey. Time was required to sort the spoils of years, so the winter of 1852 was spent in Washington, preparing his Report as Botanist to the Mexican Boundary Survey. It took three years, when he was offici- 


\section{I82 SOME AMERICAN MEDICAL BOTANISTS}

ally employed by the United States Agricultural Department to arrange the specimens sent in by governmental explorations which had accumulated at the Smithsonian. This period included a visit to Kew, England, and marked the beginning of a lasting friendship with Sir Joseph Hooker. He doubtless visited his birthplace in Gloucester and realized the vastness of the American wilderness and the grandeur of the Californian mountains, as contrasted with the smallness, but the quiet beauty, of his own Malvern Hills.

His pleasantest trip might well have been that in 1880 , when, as special agent of the United States Forestry Department, he went with George Engelmann and Professor Sargent on an expedition to the valley of the Columbia and the far Northwest. Wintering in California, he spent the following year in that state, making numerous collecting excursions north and south, including a trip to the Yosemite in June.

Various other trips followed, interspersed with much cataloguing and writing; but in I 884 he visited England and Kew again, as well as his botanical friends on the Continent.

"The summer of I 886 he spent partly with friends in Wisconsin, partly in the quiet enjoyment of his Iowa home. But even when resting, his mind did not rest-his wonderfully voluminous correspondence went on, and the microscope 
filled in his otherwise leisure hours. Again the winter was passed in San Francisco, from which city he made numerous collecting trips as before. Remaining in California, chiefly in the vicinity of San Francisco, until September, I 888, he was busily employed making special collections of Arctostaphylos and Ceanothus and in the study of these and the genus Alnus. His last visit to California was made in the spring of $\mathrm{r} 889$. Returning to Davenport in July, he made a trip to Canada and New England, visited New York and Philadelphia, and returned to his home but a few weeks before his death, at Davenport, on the 2oth of February, I890." (Dr. C. H. Preston.)

Parry discovered, during his extensive explorations, hundreds of new plants afterwards described by Dr. Gray and by Dr. Engelmann, and his name is firmly fixed in the history of West American botany. Horticulturists will not soon forget that it was Dr. Parry who discovered Picea pungens, the beautiful blue spruce of our gardens, Pinus Engelmanni, Pinus Torreyana, Pinus Parryana, Pinus aristata, and a host of others of beauty and value. Through his zeal and enterprise, many plants now familiar to American and European gardens were first cultivated. Zizyphus Parryi, Phacelia Parryi, Frasera Parryi, Lilium Parryi, and many other plants of beauty or utility bear his name, in 
commemoration of his labors, and worthily do him honor.

In the vicinity of San Diego, in I882," he rediscovered the little fern Ophiglossum nudicaule, which he had first found in 1850 , and which had ever since remained unseen. In the neighborhood of Todos Santos, or All Saints Bay, were discovered the new Ribes viburnifolium, Parry's Mexican rose (Rosa minutifolia, Engelmann), and a dwarf horse-chestnut (Aesculus Parryi), among other new plants "; also, later, in the same region, "the new spice bush (Ptelea aptera, Parry)."

In the Proceedings of the Davenport Academy of Natural Sciences, vol. ii, pp. I88, 189, Dr. Parry tells of finding ( July, 1876 ) an undescribed variety of lily growing abundantly on the ranch of the Ring brothers, near San Gorgonio Pass, in the vicinity of San Bernardino, Southern California. He says: "The specimens then collected, together with later material, obligingly furnished by Mr. Ring, have supplied the necessary means for the complete description, and the whole having been placed at the disposal of $\mathrm{Mr}$. Sereno Watson, who is now elaborating the endogenous flora of California, he has determined the same as an undescribed species, which he has complimented the discoverer by naming Lilium Parryi, Watson. At my request Mr. Watson has 


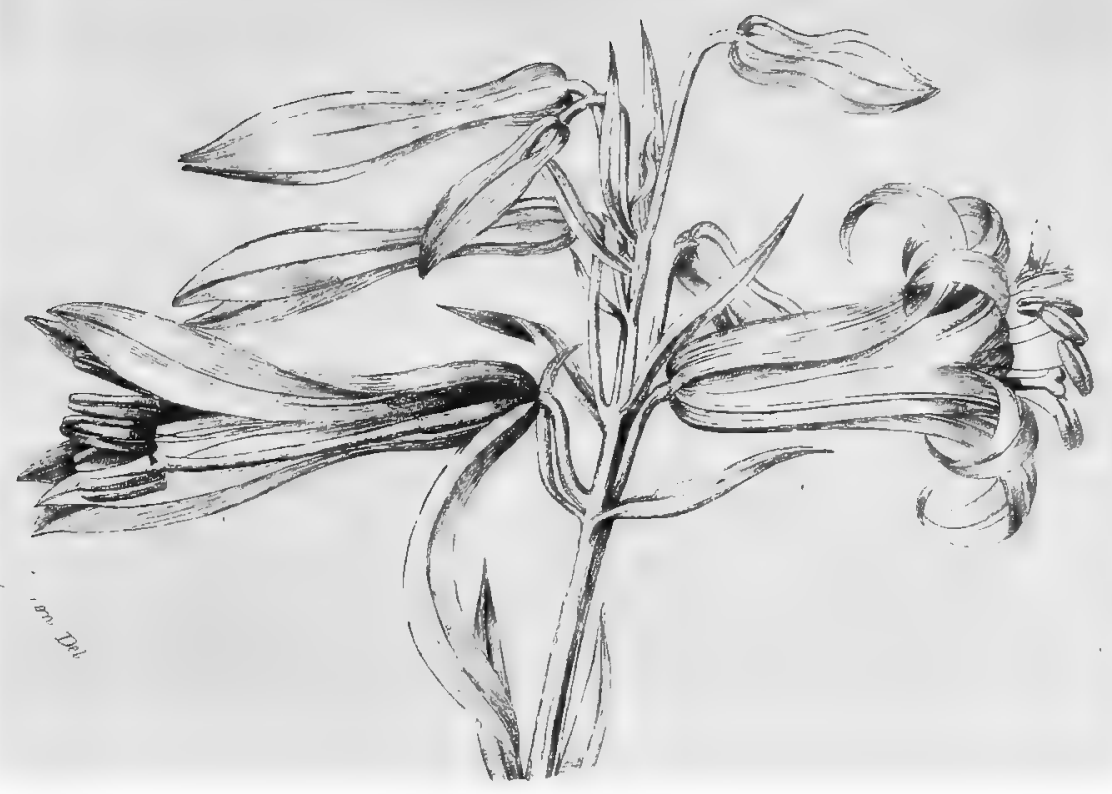

I.ILIUM PARRYI 

kindly furnished the following characterized description:

"Lilium Parryi Watson, Bot. Calif. Ined.: Bulb somewhat rhizomatous, of numerous crowded scales, fleshy and jointed, about an inch long, the upper joint broadly lanceolate; stem slender, glabrous, two to five feet high, 2-Io flowered; leaves usually scattered, occasionally the lower ones in a whorl, linear, oblanceolate, four to six inches long, and half an inch wide or less, mostly acuminate; flowers horizontal, pale yellow, sparingly and minutely dotted with purple; segments three and one-half inches long, and five or six inches wide, with long, narrow claws, slightly spreading, from the base; stamens and style a half-inch shorter, equal; anthers oblong, brownish, three lines long, capsules narrowly oblong, acutish, two inches long by half an inch in breadth.

" Of the section Enlirion, to which also belongs the California L. Washingtonianum. It is distinguished from the latter especially by its small bulbs, with jointed scales, its more scattered and narrower leaves, its smaller yellow flowers, with less spreading segments, and its longer, narrower and acuter capsules.'"

His name is borne by a peak of the Snowy Range, Colorado, bestowed by Surveyor-General F. M. Chase. 
Though his writings-some I 40 papers-if collected, would form a respectable two volumes, they are scattered throughout government reports and society transactions, a great many appearing in the Proceedings of the Davenport Academy of Natural Sciences, vols. i-v; the Transactions of the St. Louis Academy of Science, vol. ii; and the American Naturalist, vols. vi and viii.

Not only did he give freely to societies and friends, but he made for himself one of the finest herbaria in the country, a collection including over 18,000 determined specimens, representing nearly 6,800 species, together with some 1,400 specimens determined only as far as the genus. To bring the Mexican rose into cultivation, he made an extra trip into Lower California; he took much trouble to introduce the Spiraca caespitosa, or tree moss, found in the Wasatch Mountains.

"His notes and journals," says Dr. C. H. Preston, "contain little save that which is relative to his work-no mention of his travelling companions, nor of any of the unique and interesting specimens of Western humanity with whom he came in contact; yet he was deeply affectionate and particularly fond of little children."

Biography. Dr. C. H. Preston. 



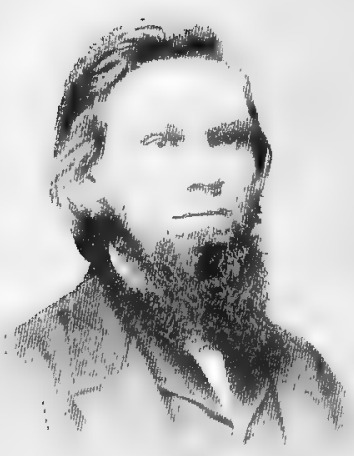

ELLIOT C. HOWE

(From a photograph taken about I865) 


\title{
ELLIOT C. HOWE
}

\author{
I 828- I 899 \\ Stropharia Howeana-PECK
}

Some of our medical botanists have left only mycological remembrances suggestive of brief life and constant renewal. Standing out in strong contrast to the grand, enduring Pinus Engelmanni or the Abies Douglassi-rocking stormdefying and rising some hundred feet in the airare two fungi, Stropharia Howeana and $H y p o x y$ lon Howeanum, which recall the work of Elliot C. Howe, the mycologist, who was born on February I4, I 828, in Jamaica, Vermont, was educated at Lansingburg Academy, and was devoted, even as a schoolboy, to fossils, animals, plants, music and chemistry. Biographers often label these young inclinings as " a love of geology, etc.," but most boys begin some natural history collection, and "a taste for chemistry" often means a six-months craze for inflicting obnoxious smells and more enduring stains on the furniture and carpets of a long-suffering family. However, young Howe's early tendencies became confirmed tastes. He also studied physiology and medicine in New York City, eking out his 
income by writing articles and reporting for The New York Tribune. When he had his medical degree he went to Troy to practise, " giving such attention as he could to music, physiology and botany."

The harmonies of nature apparently attracted him more than disease, for he became teacher of these three sciences in Charlotteville Seminary. There was a large swamp near the school, and in it Howe found the beautiful American Jacob's Ladder, Polemonium Van Bruntiae, Britton, this was the first-known New York locality for a plant then thought to be the same as the European Polemonium coeruleum, Linnaeus.

The Charlotteville Seminary being accidentally destroyed by fire, Howe took the same professorships in Fort Edward Institute, where he "vigorously studied mycology" and, incidentally, the charms of a fellow-teacher, Emily Z. Sloan, who became an "Howeana" and blossomed thenceforth beside him.

After thirteen years of active medical work in Yonkers, New York, he went to Lansingburg and found sufficient employment in botanical excursions, and in studying local flora. He became a member of The Torrey Botanical Club, and got in touch with fellow-workers by letter and exchange of specimens. In 1894 he published, with Dr. H. C. Gordinier, The Flora 



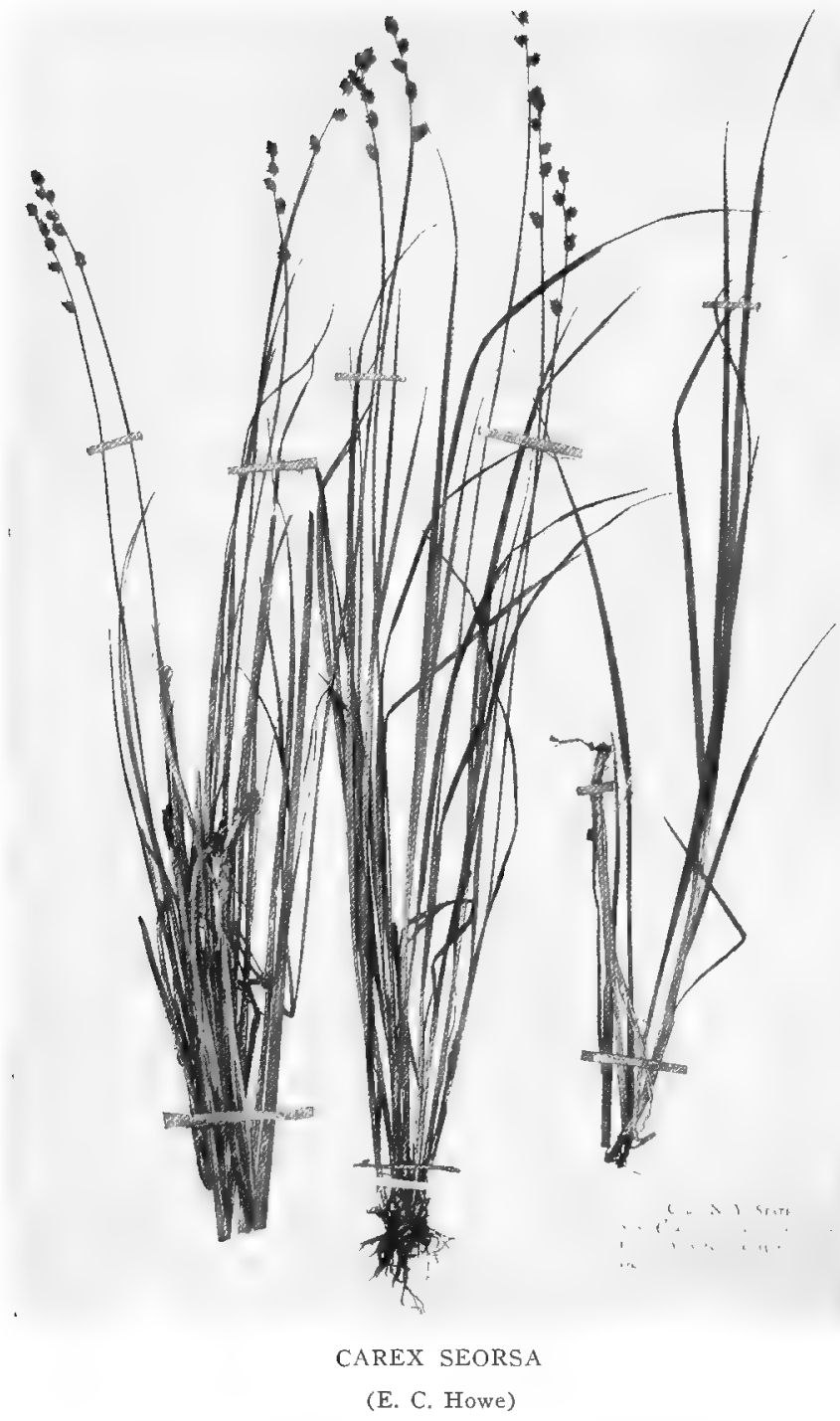


of Rensselaer County, a Record of the Phaenogams and V ascular Cryptogams, recording I,345 species and varieties. He also wrote the descriptive article on the New York species of Carex (48th State Museum Report), describing a new species, Carex Seorsa, and two new varieties, $C$. lenticularis merens, Howe and C. Emmonsii distincta, Howe.

He claimed the hybrid character of Carex Sullivantii, Boott (Botan. Gaz., February, I88I), now generally admitted.

In 1892 , seven years before his death, he lost the use of his limbs and became a helpless, but cheery, invalid, his wife and sons and daughters all helping by bringing plants and making his herbarium. Music, too, whiled away many a long hour, and a past generation will remember one of his songs, The Old Arm Chair, which London took up and sang with America; while the musicians of both armies during the Civil War enjoyed The Wanderer's Dream. This musical mycologist, after seven years of physical imprisonment, was liberated into the larger life on the $2 \mathrm{~d}$ of March, I 899.

Bull. of the Torrey Botanical Club, May, 1899. Charles H. Peck. 


\section{WILLIAM HERBST \\ I 833-1 907}

Sparassis Herbstii-PECK

The first human glimpse of William Herbst amongst the scanty biographical details obtainable is as a boy riding with his father, Dr. Frederick W. Herbst, to visit patients and beguiling the time by gathering and studying flowers in the fields during the long waiting at sick men's doors. The father had come over from Saxony in I 825 , and William was born in Reading, Bucks County, Pennsylvania, on September 24, I833. His only text-book was an old German one, but "he was fascinated with the fanciful names given to the specimens" and after a while got a botanical work by Mrs. Lincoln. He went to two or three academies and finally to one in East Hampton, Massachusetts, where he studied botany under Dr. Edward Hitchcock and began to form an herbarium, which he continued while studying medicine with his father before he went to Jefferson Medical College, Philadelphia, where he took his M. D. ( 1855 ).

Finally he settled down to practise in the (then) small village of Trexlertown, Lehigh 
County, Pennsylvania, and gave all his spare time to studying the flora of the state, in later years specializing in fungi, especially the Basidiomycetes. His biographer says, "for a number of years he occupied the chair of botany at Muhlenberg College, Pennsylvania," but we would also fain know how he fared and did when not in the chair, of some of his pleasures in finding new plants, and of his friendship with Prof. C. H. Peck, the botanist, who on August 25, I894, writes to him: "That was a splendid fungus you sent me. It is an undescribed species of $S p a-$ rassis. I propose to name it, with your consent, Sparassis Herbstii, sp. nov. . . . Thanks for your kind offer to send me some more specimens of Queletia mirabilis, Fr. So far you are the only one to find it in this country."

Herbst found time to write a tolerably large illustrated volume (229 pp.) on the Fungal Flora of the Lehigh Valley, Pennsylvania, 1899, and when he died, in December, 1907, his widow gave all his specimens to the Academy of Natural Sciences of Philadelphia.

Personal Communication from Caroline Herbst.

The Botanists of Philadelphia. J. W. Harshberger. 


\section{GEORGE EDWARD POST}

$$
\text { I 838- I } 909
$$

Postia Lanuginosa-BOISSIER AND BLANCHE

Post lived his long life as a medical missionary in far-off Syria, becoming equally well-known for his surgical and for his botanical work. Born in New York City, December I7, I838, he was the son of Dr. Alfred and Harriet Beers Post. He graduated from the old New York Free Academy, now the College of the City of New York, in 1854 , taking his master's degree three years later. Encouraged by a botanist friend, he became an eager collector of plants and prepared a Flora of the region round New York, which he presented as his graduation thesis. He then entered the medical department of the University of New York, from which he graduated in I86o. One year afterwards he entered the Union Theological Seminary.

Dr. Post was elected in I 868 to the professorship of surgery in the Syrian Protestant Hospital at Beirut, which is maintained by the Presbyterian Board of Foreign Missions, and this he held until his death. He was also surgeon to the Johanniret Hospital, in Beirut. 


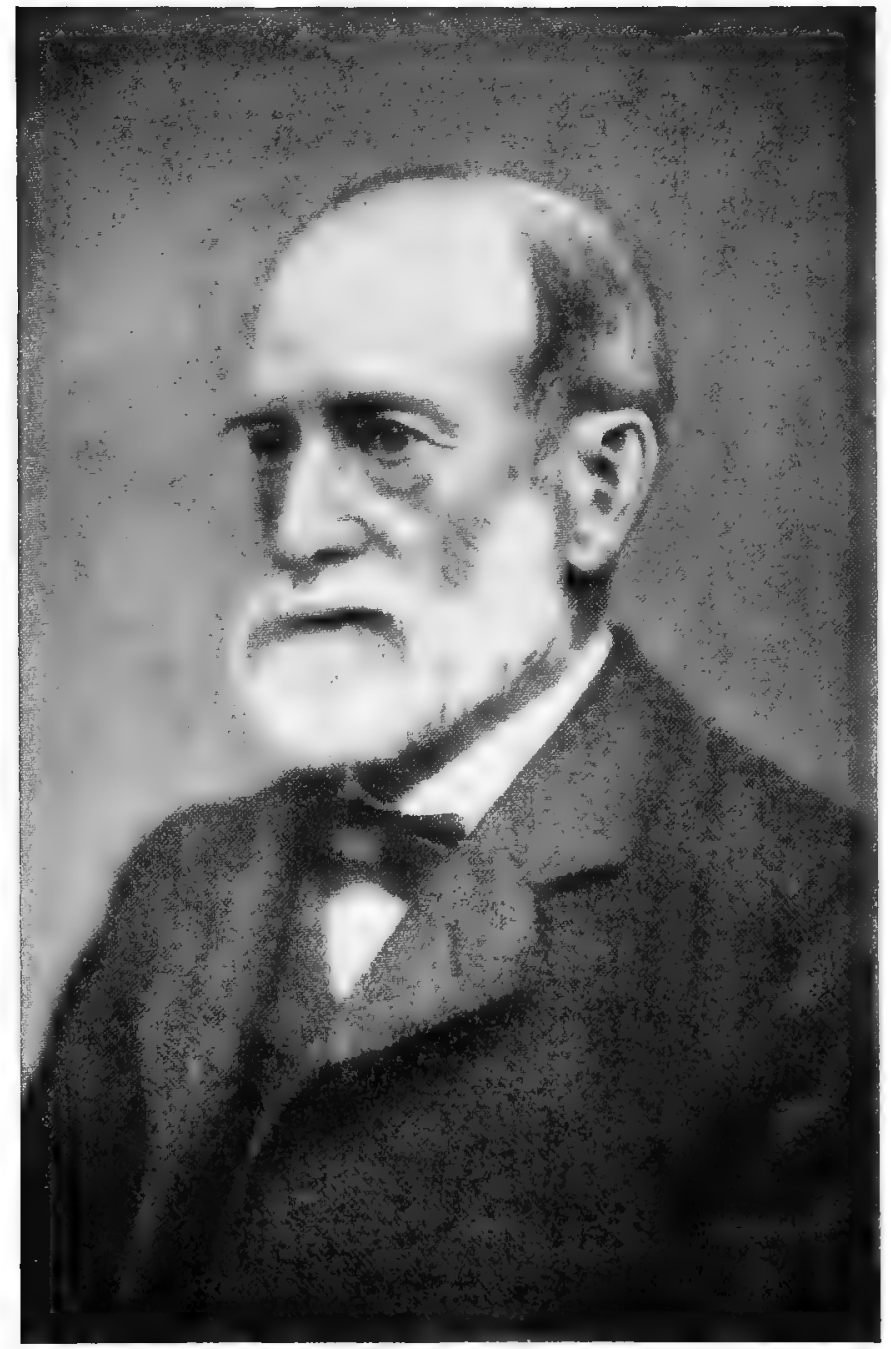

GEORGE EDWARD POST

(E1liott \& Fry, photographers) 

The Protestant Hospital was then a small, struggling institute with few students. Dr. Post lived to see it with an enrollment of eight hundred, representing some twelve or fourteen nationalities.

He had no light task; for class room, the hospital, private practice and missionary as well as scientific duties all clamored for him. The teaching was in Arabic, which Post had mastered when in Tripoli, before going to Beirut. Of the preparation of text-books in Arabic he had also to bear a large share. One was on Structural and Systematic Botany, and a Flora of Syria, Palestine, Sinai and Egypt ${ }^{1}$ (not to be confused with his much larger and more complete Flora, in English, published many years later). From the time he landed in Syria he began collecting the plants of the country, and this herbarium, which steadily grew in size and value until, at his death, it numbered over I 5,000 species, was his pride and joy and the foundation for all his subsequent work in botany. One of the last botanical tasks that he undertook was the careful

1 "Post's Flora of Syria, Palestine, and Sinai has no date on the titlepage. It was printed on the Mission Press in Beirut, and consumed about fourteen years ( $1883-1896$ ) in the printing; but I can find no evidence that it was issued in parts. The entire work seems to have first come into the hands of the public in $\mathbf{1} 896$. Perhaps there may be a later edition, but as far as I know this was the only one." (J. H. Barnhart.) 
I94 SOME AMERICAN MEDICAL BOTANISTS

going over and rearrangement of this herbarium in the George E. Post Science Hall of the Syrian Protestant College.

It was his habit to throw the whole of his tremendous energy, enthusiasm and perseverance into anything that he undertook, carrying it through to a finish, to the very best of his ability. He never idled away his spare hours, and developed the power of concentration to a remarkable degree-the greater, perhaps, because increasing deafness shut out ordinary sounds. He was able to take up any task to which he set his mind, at a brief notice, and to become at once absorbed in it. When weary with labor, in spite of his heavy responsibilities, he could drop off to sleep like a little child. He was accustomed to get up at sunrise or before, and his daily round of professional duties often made it a wonder to me how he found time and strength to pursue botany. But to him it was a first love, which with advancing years never lost its charm. During the busy time of the year he would seek the seclusion of his herbarium for such time as could be spared from his other tasks. But it was chiefly during the long summer days, in the sweltering heat of the plains, while others were enjoying the cool of the mountains, that he would spend hours at a time in his beloved herbarium, working over his collections and his Flora. 
Of nervous temperament, yet possessing a constitution of iron, light in build, of medium height, wiry, very active, and a fine horseman, and with a keen, trained eye that no plant could elude, he would travel, on his botanical excursions, from early morning till daylight failed, scouring mountain, hill and dale, sandy coast and. desert, collecting plants. Oftentimes he would lean from the saddle, with an arm about his horse's neck, and get specimens without stopping to dismount. It was his habit to collect many of each species of plants, the duplicates serving for exchange with his botanical correspondents, among whom were Baker of Kew, Boissier, Bornmüller and others.

On his botanical trips, taken during holiday time, his method of collecting was to carry a large number of heavy cartridge-paper driers in Syrian-made, woven-wool saddle-bags. Handfuls of specimens were introduced en masse between the driers until a considerable quantity had thus been collected. Then, when for any reason a halt was called, he would spring from his horse, and with speed attained by long practice, arrange his plants in their final form between the driers, which were firmly tied into packages of suitable thickness, and placed in the saddle-bags of his travelling companions, fresh sheets being taken from them and placed in his 
I96 SOME AMERICAN MEDICAL BOTANISTS

own saddle-bags for further specimens. At the close of a heavy day's collecting, the numerous packages had only to be strapped into the plantpresses, to be loaded upon the pack animals in the morning. Travelling all day in the hot Syrian sun, and exposed to the wind, the plants would often dry without requiring transfer. Leaving the muleteers with their pack-animals to accomplish the stage determined upon by the easiest route, he would sometimes strike off into the mountains or the wilds, covering two or three times the distance traversed by the caravan, and arriving at camp at close of day laden with spoils. The muleteers did not always receive with enthusiasm their rapidly increasing loads. Syrian custom-house officials, having no knowledge of herbaria, often looked askance at these huge collections and wished to confiscate them. But with his perfect knowledge of the Arabic language and ways of thinking, and with an innate power of persuasion, he always succeeded in getting his collections safely through. No plant, however spiny and unwieldy, discouraged him; many of his discoveries were among plants of this description, in which the Syrian flora abounds. Huge heads of spiny Onopordon with forbidding leaves; formidably armed species of Astragalus and Acantholimon; cones of pine, cedar and fir; towering huge-leaved mulleins, 
giant umbellifers with large, delicate and intricately cut leaves-all furnished their toll to his omnivorous plant-presses. In his Flora he describes no less than fifteen species of mullein, and eight of Astragalus, new to science.

Once, in the spring of 1890 , he made a botanical trip to Palmyra. Growing on the rocky crags of Jebel Bilas, in the Syrian Desert, he found the basal leaves of two large umbelliferous plants which he had never seen before. These leaves he carefully collected, as they were the only part of the plants developed. From his knowledge of the Umbelliferae he was able not merely to recognize the genus to which the plants belonged, but to construct a detailed description of the probable appearance of the mature plants. On a second trip to Palmyra, in the summer, he found and collected mature specimens closely corresponding to the descriptions he had constructed, and which proved to be two species new to science, named by him Ferula Bilasi and $F e$ rula Barbeyi.

Collecting was but a part of the labor. All the specimens were studied and arranged by himself, the list of plants collected on each journey, with habitat and date of each species, together with a full description in Latin of the species and varieties new to science, being published in a series of ten monographs entitled Plantae Pos- 
tianae, five of which appeared first in the $\mathrm{Bul}$ letin de l'Hérbier Boissier and one in Mémoires de l'Hérbier Boissier. Previous to the publication of these, some of his descriptions of new species appeared in The Journal of the Linnaean Society, vol. xxiv ( I888). He himself was a member of The London Linnaean Society, of the Botanical Society of Edinburgh, and of The Torrey Botanical Club of New York. The enumeration of species collected was in part made in collaboration with $M$. Eugène Autran, Curator of the Boissier Herbarium of Geneva, but he named and described his own new species and varieties. All told, these numbered over $\mathrm{r} 2 \mathrm{O}$ new species and nearly 300 new varieties of plants in his Flora of Syria, Palestine and Sinai. Reckoning the total number of species described in this Flora as 3,500 , he was the first to determine, name, and describe more than one-thirtieth.

Familiarity with the geography and physical characteristics of Syria and Palestine was shown by a paper on The Botanical Geography of Syria and Palestine, read before the Victoria Institute, and published with a map in the Proceedings of the $V$ ictoria Institute. In this paper he maps out Syria and Palestine into ten distinct botanical regions, the characteristics and flora of each of which he sets forth.

In the spring of 1882 he made a trip to Sinai in company with Dr. Henry M. Field, which is 
graphically described by the latter in his book On the Desert. During the month's journey, about 350 species were collected, mostly unknown in Syria. While on the desert, homeward bound, he was taken very ill with high fever; but he decided to press on. "He rose heavily and wearily," writes Dr. Field, "and bracing himself with a strong dose of quinine, mounted his camel. As soon as he was in the saddle, his spirits began to rise. The fresh air and the motion gave him new life. But what relieved my fears was to see his old passion for flowers kindle at the sight of some new specimens which he could gather for his collection of the flora of the desert. He could not resist the attraction of a new plant, and I verily believe, if he had been in articulo mortis, that the sight of a new flower brought to his bedside would have caused a smile of satisfaction to spread over his dying features. ... When he first came upon the squill plant, he could not restrain his excitement. 'That plant,' he said, "is never found except near the sea, or at least within the reach of the salt air. We are approaching the Mediterranean. It may be yet fifty or sixty miles off, but we are getting near it.' How delightful is this enthusiasm of the man of science, which can make him forget illness and the fatigues of the desert!"

A botanical journey was made with his son Bertram through Eastern Turkey, from Mersine 


\section{SOME AMERICAN MEDICAL BOTANISTS}

to Mount Ararat, in the summer of 1906, and the collection made was large and valuable. Dr. Post was working upon these plants as he had opportunity, when death snapped off the sweet bloom of life. A number of new species were discovered on this trip, but their description is still unpublished. One of the plants collected was a pretty species of Postia. Many years ago, a new genus of Compositae was named Postia for him by Boissier and Blanche. The following species of Syrian plants were also named for him by fellow-botanists: Cousinia Postiana, Winkler; Centaurea Postii, Boissier; Tracheliopsis Postii, Boissier; Ajuga Postii, Briquet.

On one of the high mountains above the Cedars of Lebanon, he discovered two specimens of a new genus, one of which was submitted to Winkler and Barbey for determination. This they named Autrania pulchella, its description being given by them in Plantae Postianae, fasciculus iii, following which are these words: "Habitat in Syriae monte Rijàl-el-Asherah altitudine $8500^{\prime}$, ubi cl. Post Julio mense anni r 89 I generis novi exemplaria duo detexit, quorum unum illustrissimus Post sub No. I 36 liberalissime herbario horti Petropolitani communicavit."

The Flora of Syria, Palestine and Sinai, in English, was his magnum opus in Botany. The volume of 9I I pages represents the labor of over thirty years, although for many years he was only 


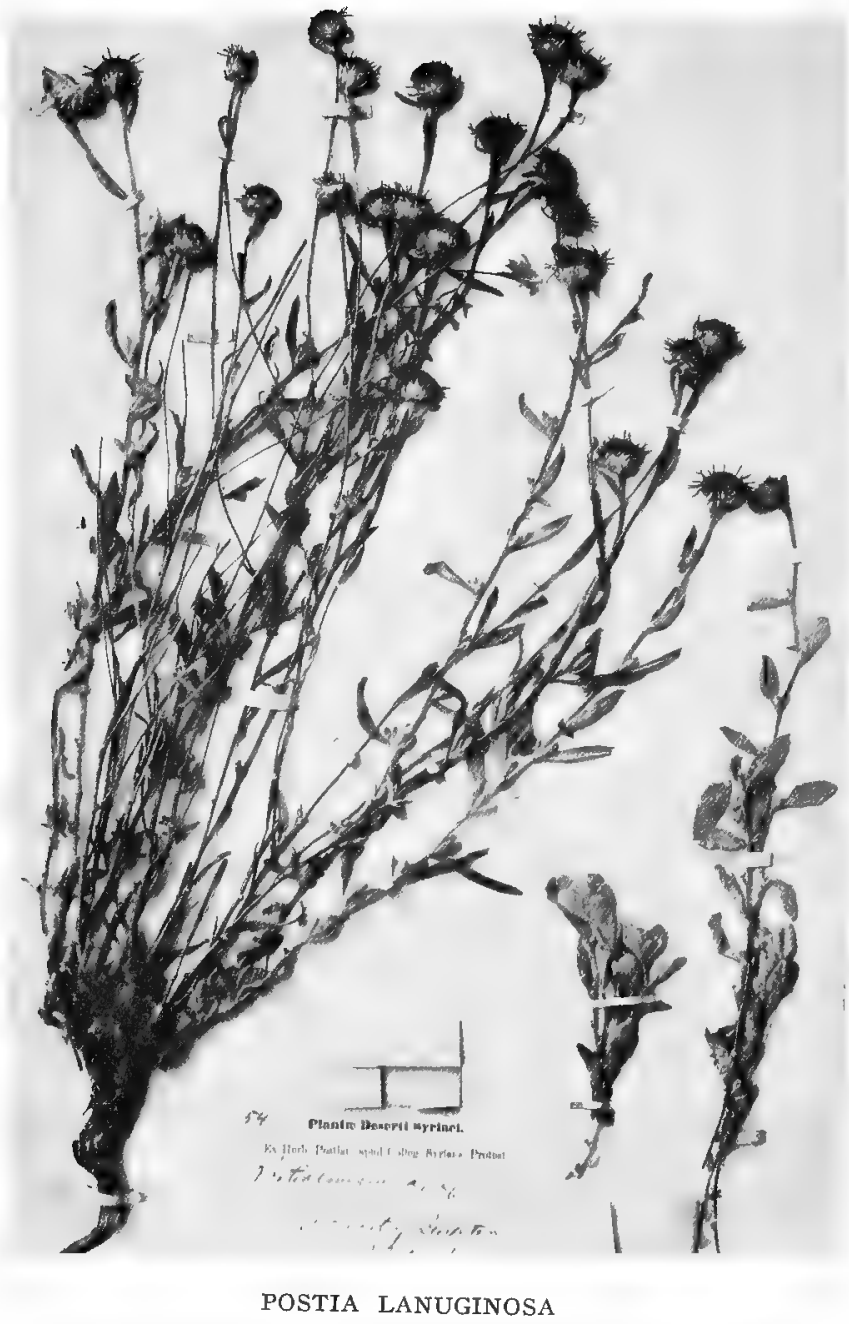



collecting and studying the flora, with no idea of undertaking the Herculean task that was finally accomplished in the face of such obstacles. He himself drew most of the illustrations, and superintended the execution of the woodcuts. In the Introduction he remarks: "The very large number of species found in a country so limited is to be accounted for by its microcosmic character... the district covered by our work contains 126 Orders of phaenogams and acrogens, 850 genera, and about 3,500 species. The significance of these figures will appear if we recall that our region is only about as large as England, or as the State of New York." The number of species described in this Flora-and there are doubtless others awaiting discoveryis nearly three times as great as that contained in Bentham's Illustrated Handbook of the British Flora.

Being an authority on the botany of the Holy Land, he was in constant demand for articles on kindred topics for various Bible Dictionaries and for religious and scientific periodicals.

He studied the plant and animal life about him to such advantage as to gain membership in European societies and to give the college textbooks in Arabic on the botany, mammals and birds of Persia, besides treatises on Surgery and Materia Medica. For his work in the missionary and medical fields, he received the decoration 
of Othnanieyh of Turkey, of the Ducal House of Saxony, and of the Red Eagle and Knights of Jerusalem of Germany.

He married Sarah Reed, of Georgetown, District of Columbia, and three children survive him. Of his sons, Bertram Van Dyck became a professor of biology in Robert College at Constantinople, and Wilfred N., surgeon at the American Hospital, Caesarea.

He gave much time, during the last few years of his life, to starting a Museum of Economic Botany, which now forms an interesting and valuable feature of the hall at Beirut which bears his name.

His unflagging energy and zeal finally burned itself out. He lived his three-score years and ten, the lamp of life going out in his seventy-first year. Shortly before his death he remarked wearily, "I have worn out my bodily machine." But it was impossible for a man of his nature to do otherwise and be happy. A few days after that remark, a discerning friend placed in his still right hand some generous ears of ripe wheat-a beautiful symbol that his life had not been lived in vain.

Personal communication from Dr. Bertram V. D. Post.

New York Observer, October 7, r9o9.

New York Evening Post, October 8, rgog.

The Missionary Review, New York, December, 1909.

Stone's Biog. of Eminent Amer. Phys. and Surgs. 



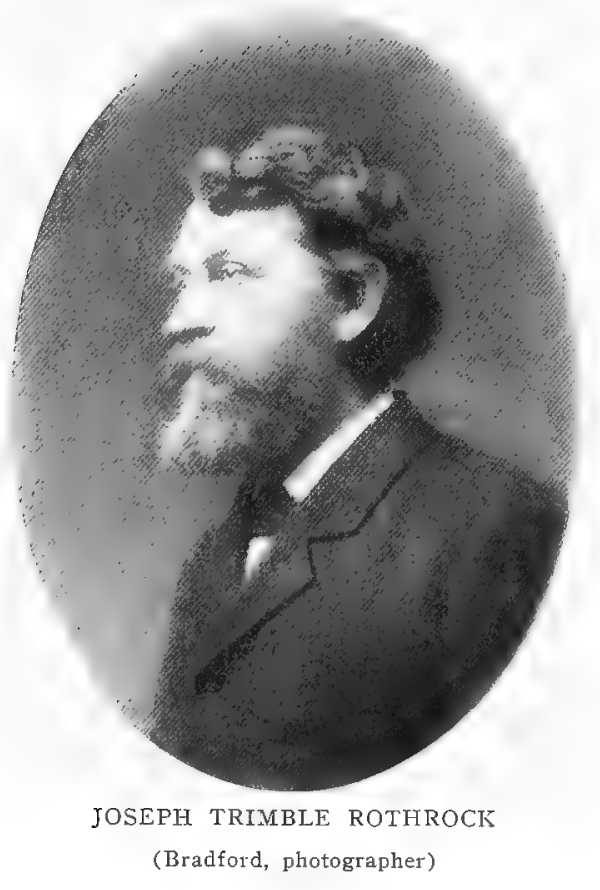




\title{
JOSEPH TRIMBLE ROTHROCK
}

\author{
$1839-$ \\ Rothrockia cordifolia-GRAY
}

I asked my old friend Dr. Rothrock to let me know something of his career, and he has told it so well that the story is given as it was sent to me:

"The son of Dr. Abraham and Phoebe B. Rothrock, I was born April 9, I839, in McVeytown, Mifflin County, Pennsylvania. My education in early life was greatly interfered with by lack of vigorous health rather than by actual disease; open air was an absolute necessity to me, and throughout my entire life, I have sought the 'out of doors' as a refuge against impending physical ills.

"When sixteen, the first serious attempts at education were begun, the village school being the starting-point. From this I passed to Freeland Seminary, in Montgomery County, now Ursimus College. A year was spent in Freeland. Then came a break-down in health, and restoration was sought by taking a position as an axeman in the civil engineer corps then located in what is now the Philadelphia and Erie Railroad 
through the wilds of Elk and Forest Counties, in Pennsylvania. It was a genuine pioneer life. Roads-and these bad-were few and far between. There was a scant population, with only here and there a budding village. The streams contained many trout, and deer were in every forest, but not a house was built in the now prosperous town of Kane. No extensive lumbering or mining interests existed there at that time though the hills were black with timber and extensive deposits of coal were known to exist.

"The flora of the region contained many plants that I had never seen. The Trilliums and the Hobble Bush (Viburnum) were new to me. My mother was a distant relative of Dr. William Darlington and, like him, fond of botany; so from her I inherited this fondness, she being my first botanical teacher, while Darlington's old Florula Cestrica was one of three books which constituted my botanical library. The other two were Torrey's Botany and Mrs. Lincoln's First Lessons in Botany.

"I had never before seen such massive white pines or hemlocks. The dense woods of beech, yellow birch and sugar maples amazed me. I allude to these small impressions because they shaped my life. If the woods of my own state contained so many things of interest, what could I not find in regions unexplored? I would be- 
come an explorer! The idea took possession of me. But I must prepare myself by study; so from that time on, I worked in earnest. The report of Fremont's explorations, I842-43-44. and later the explorations of Dr. Kane, came into my possession, adding fuel to the flame.

"When I returned to school at Academia (then a well-known preparatory school in Juniata County), I fitted for admission to Lawrence Scientific School in Harvard University, and in I 860 was accepted by Prof. Asa Gray as a special pupil in botany, working in his herbarium. He was one of the botanical magnates of the world, beyond question deservedly so.

"No youth was ever more fortunate in his teacher. Dr. Gray was kindness personified, though a strict disciplinarian and a most merciless critic of a student's work. I owe more to him than to any other man, and I never think of him without veneration. I also attended the lectures of Louis Agassiz and Jefferies Wyman, and enjoyed the personal friendship of these great teachers.

"The Civil War was upon us. I volunteered as a private in Company D, I3 Ist Regiment Pennsylvania Volunteer Infantry, and was eighth corporal in the company. Getting wounded in the right thigh at the battle of Fredericksburg, I 862 (Burnside's fight), I was taken to Carver 
Hospital in Washington, but was transferred thence to Judiciary Square Hospital, the site of the present Pension Building, where my friend, Prof. B. G. Wilder, operated and removed the ball. We had been fellow-students in Harvard, and before enlisting I had asked him to remove the ball if I were wounded in the leg. He assented, though neither of us supposed it would so happen. In July, I863, I was promoted to the captaincy of Company E, 2oth Regiment, Pennsylvania Volunteer Cavalry, and was assigned to duty in West Virginia, where my chief work was to break up the system of bushwhacking which was then rife in that region. I was mustered out at the expiration of my six months of service as captain, and then returned to Harvard to complete my course of study. A little episode interfered with my intention; the venerable professors of Harvard University, to show their loyalty, had formed themselves into a military company. Probably no one expected that they would be called out; but they were asked to garrison the antiquated fort at Long Point, near Provincetown, on Cape Cod. Professor Gray was a member of the company and determined to go with it. I insisted that he was too old, and at any rate Harvard could spare me better than it could him, so after much persuasion I succeeded in overcoming his reluctance. So for 
three months I was soldiering again. It is fair to say that the service was neither very onerous nor bloody. I returned in time to take my degree of Bachelor of Science in July, I864.

"That fall I entered the medical side of the University of Pennsylvania. The course of lectures was hardly over before I was requested by the Smithsonian Institution to join an expedition to British Columbia and Alaska, and under the auspices of the Collins Overland Telegraph Company (the Atlantic Cable had thus far been a failure) to secure telegraphic communication by the North Pacific regions with Asia. Our leader was Robert Kennicott, Major Frank Pope my immediate commander. Thus I was engaged from June, I 865 , to June, I 866 . The scientific results of our part of the expedition were not much, as I was mainly assigned to other than scientific work; and what plants I collected were lost in transportation down the Fraser River.

"I began to study medicine again in the winter of 1866 and 1867 , in Philadelphia, and took my M.D. in the spring of 1867 , going immediately afterwards to the State Agricultural College as Professor of Botany, but remaining there only two years.

"In May, I869, I married Martha E. May, to whose influence in shaping my subsequent life I must pay a well-deserved tribute; and in my 
charitable enterprises she has always given cordial support, even when results were most unremunerative and discouraging.

"In I 869 we removed to Wilkes-Barre, Pennsylvania, where I was fortunate in working up a good practice. It has always been a pleasant thought that I was enabled to take an active part in starting the Wilkes-Barre Hospital on a long career of usefulness as one of the leading hospitals of the state.

"In the spring of I 873 my health gave way so completely that I was obliged to abandon medical practice. A position as Botanist and Surgeon to the Surveys West of the rooth Meridian, under the direction of Lieut. George $\mathbf{M}$. Wheeler, U. S. Engineer, was offered and gladly accepted. I was assigned to duty in Colorado under Lieut. William M. Marshall. There was little medical duty, but Prof. John Wolf and I together managed to collect about ten sets of plants, which would average one thousand species each. I must say, however, that Professor Wolf deserves more credit for this than I do, as much of my time was taken up with general executive work. I did, however, manage to place the barometer on the top of a large number of the highest peaks in central and southern Colorado and obtain readings there. 
"In I 874 I was put in charge of a small scientific division, and was assigned to duty in New Mexico and Arizona, associated with that distinguished ornithologist, Mr. Henry W. Henshaw, now chief of the Division of Economic Zoölogy, in the Department of Agriculture, Washington.

"The results of our joint labors were, on the whole, somewhat remarkable, and have contributed much to knowledge of the region. I made a dozen sets of plants which averaged probably I, IOO species to each set. In I875 I was assigned in the California division and operated mainly in the central portion of the state.

"The botanical results of my three years of service on this survey can be found in vol. vi, United States Geographical Surveys $W$ est of the Iooth Meridian, Lieut. G. M. Wheeler, U. S. Engineer, in charge, quarto, pp. 404, thirty illustrations. The volume enumerates and generally describes I, 168 species, belonging to 637 genera, which in turn represent 104 natural orders of plants. In the preparation of this volume I was assisted by almost every botanical specialist in the country, so that it may fairly be said that the book has been and is still considered a standard one.

"A considerable portion of the volume is devoted to topographical considerations and to the 


\section{$2 I O$ SOME AMERICAN MEDICAL BOTANISTS}

economic relations of the plants of the Southwest. Much of this material was wholly new. The socalled ' loco plants,' which were a cause of great injury to the stock-raisers, came under my observation and were as thoroughly described in appearance and in effects as the early knowledge of the times allowed. It is fair to remark that, though I left much to be said about them, little of anything I did say has since been disproved. "In $1876 \mathrm{I}$ had the happy idea of taking weakly boys in summer out into camp life in the woods and under competent instruction mingling exercise and study, so that pursuit of health could be combined with acquisition of practical knowledge outside the usual academic lines. I founded the school on North Mountain, Luzerne County, Pennsylvania, and designated it a School of Physical Culture. There had been, I think, but a single attempt to do this work at an earlier period. The multitude, now, of such camps shows the seed fell into good ground.

"I was elected Professor of Botany in the University of Pennsylvania in 1877 , and served until I89I, when I devoted myself wholly to conducting a forestry propaganda in Pennsylvania. I had, however, in the meantime, been also giving

${ }^{1}$ This camp was taken over and continued for two years by Dr. Lewis H. Taylor, Herr Frank and myself. We received and taught about twenty boys from upper schools and from college, in zoölogy, meteorology and botany. H. A. K. 
a course of summer lectures on Botany and Forestry in Horticultural Hall, in Fairmount Park, under the so-called Michaux bequest, to the American Philosophical Society.

"In 1893 the time seemed to be ripe for legislative action. I drew up a bill creating a commission to investigate and report upon the forestry condition of the state.

"This bill was passed by the legislature, and the sum of $\$ 25$,000 was appropriated for the work. The report was to be made to the legislature in I895. My active colleague in the work was William F. Shunk, one of the most accomplished civil engineers that the country has ever produced. We labored incessantly during the time allowed and, I think, produced as good a report as could reasonably have been expected. We were conscious of its shortcomings, but it was kindly received over the commonwealth, and not less than 50,000 copies were distributed over the state. The book contained 361 pages, 47 fullpage and other illustrations, and a number of maps.

"The State Department of Agriculture was created in $\mathrm{I} 895$. In this, there being a division devoted to forestry, I was appointed, late in the year, Commissioner of Forestry, with Robert S. Conklin as my clerk. In IgoI forestry had become important enough in public esteem to war- 
rant the creation of a special department, which conferred a new dignity upon the Commissioner of Forestry and made him a member of the Governor's cabinet.

"This position I held until I904, when I resigned the office, for I had been twenty-six years a laborer in the interest of Pennsylvania forestry. It is for others to place an estimate upon my efforts. The very day I resigned, a vacancy occurred in the advisory board, and I was immediately appointed to fill it. (I still hold the position, without salary.)

" In I902, 'without warrant of law,' I established the principle, near Mont Alto, of opening homes for consumptives on the State Forest Reserve. A few cheap shacks, costing on the average about fifty dollars each, were erected, and in these such suitable, incipient cases as cared to come, furnishing their own food and preparing it, were allowed to stay and obtain such benefit as they could from forest air, food and rest.

"The experiment proved a success and, by I907, legislative appropriation, aggregating $\$ 23$, ooo, had been made for its support. Beyond doubt great good was done, the demands for admission being always in excess of our receiving capacity. In 1907, on the request of the Forestry Department, the camp was formally turned over to the newly created Department of Health. 


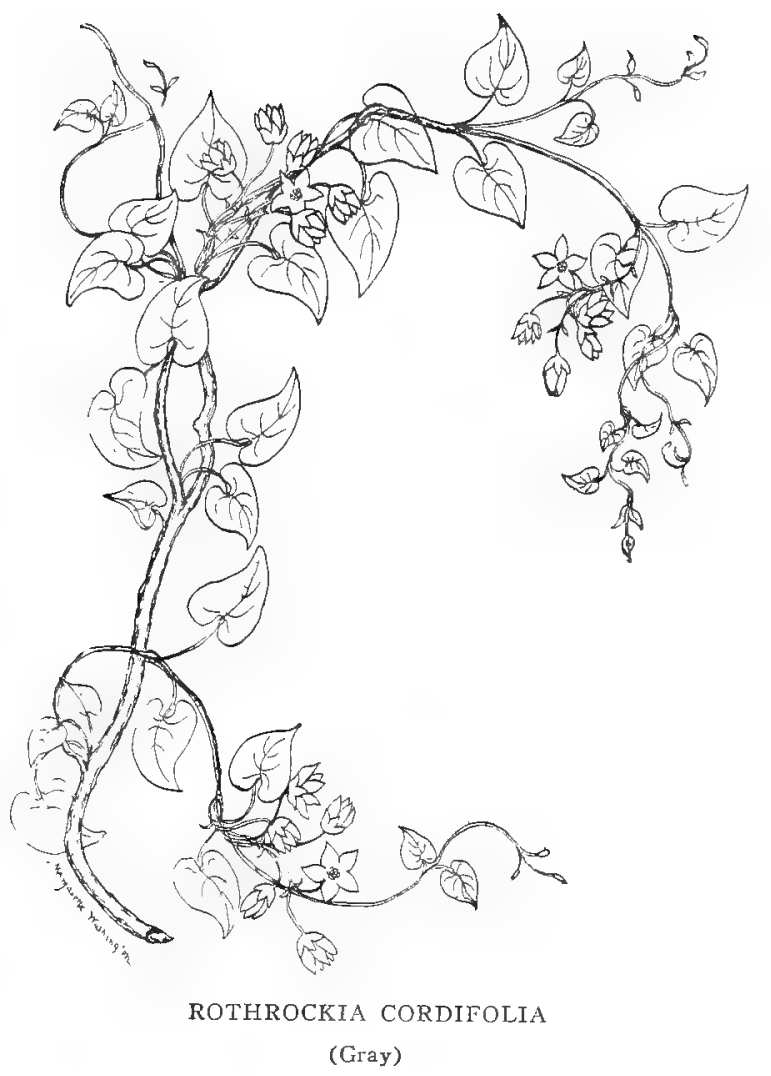



It has since received large legislative appropriations, and under the direction of Dr. Samuel G. Dixon, Commissioner of Public Health, has grown into a great sanatorium, holding 850 patients.

"I am a member of the usual number of learned societies, and in religious faith an Episcopalian, and politically a Republican, when my conscience will endure it.

"I have quite a number of plants loaded with my name: first there is, from Lower California a genus Rothrockia which belongs to the family Asclepiadaceae. Then come Artemisia Rothrockia, Halenia Rothrockii, Nama Rothrockii, Pentstemon Rothrockii, Stachys Rothrockii, Townsendia Rothrockii. There are several others which I have lost sight of, scattered through various publications, and which I have now no means of tracing since I sold my library and herbarium to the Field Museum in Chicago.

Joseph Trimble Rothrock." 


\section{HARRY HAPEMAN}

I 858 -

Sullivantia Hapemani-COULTER

I asked Dr. Harry Hapeman to give me some information relative to his work, and he tells me:

"I was born at Earlville, Illinois, on February I, I 858 , and graduated M. D. at Rush College, in 1882 . Having always been an ardent lover of everything in nature, I have made the study of botany largely my recreation. Coming to $\mathrm{Ne}$ braska in times when the flora of the region was not fully known, I interested myself in collecting botanical material for the Nebraska University, wholly as an amateur, and working in my vacations. About I89o or I89I, Dr. Bessey, of the Nebraska State University, attempted to catalogue the known plants of Nebraska, and asked me to report any I might find. During the two following years he succeeded in adding nearly 200, many of which were the fresh-water Algae. "Since that time, my principal collecting has been in Wyoming, Colorado, Texas and the Hawaiian Islands. One of my new species, from Wyoming, was named Sullivantia Hapemani, 


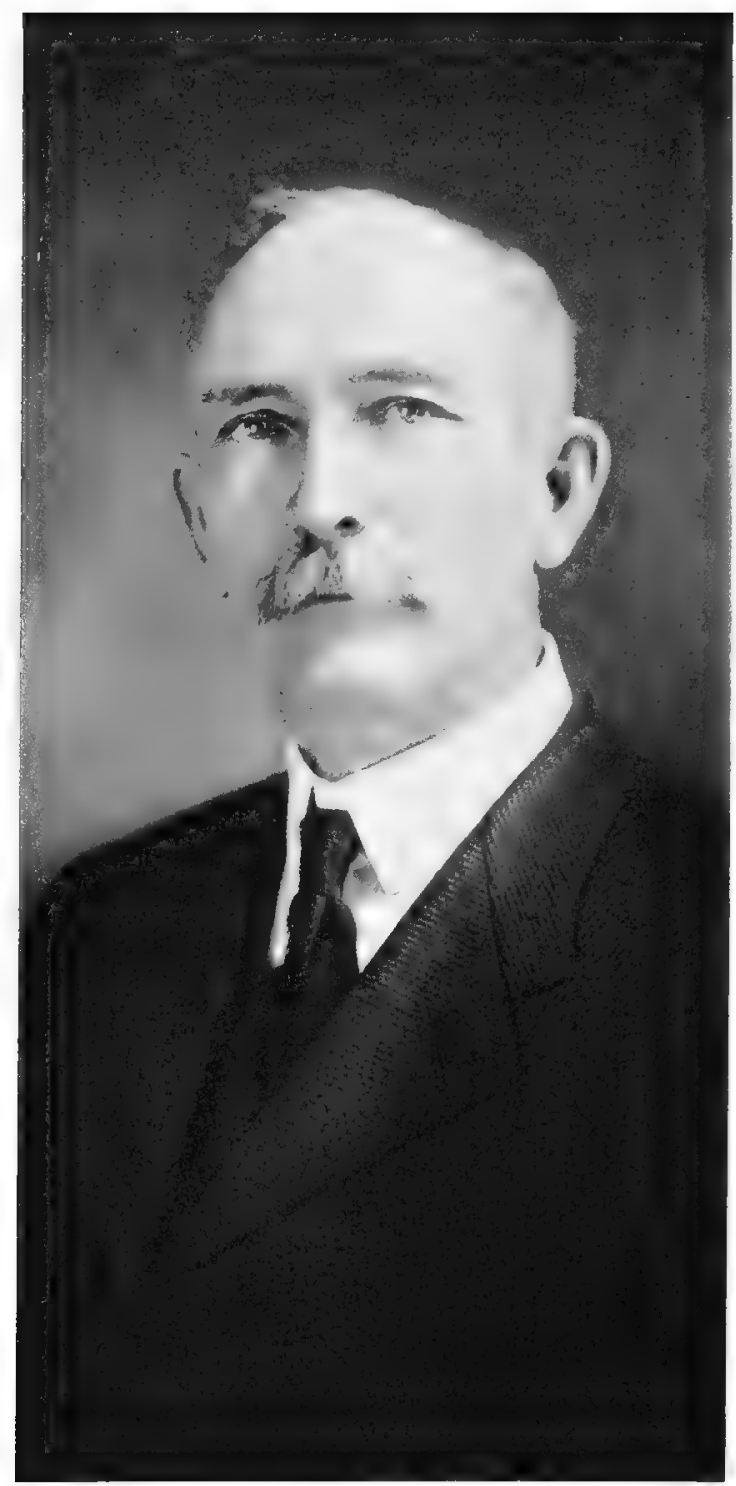

DR, HARRY HAPEMAN

(Lumière Studio, Omaha) 



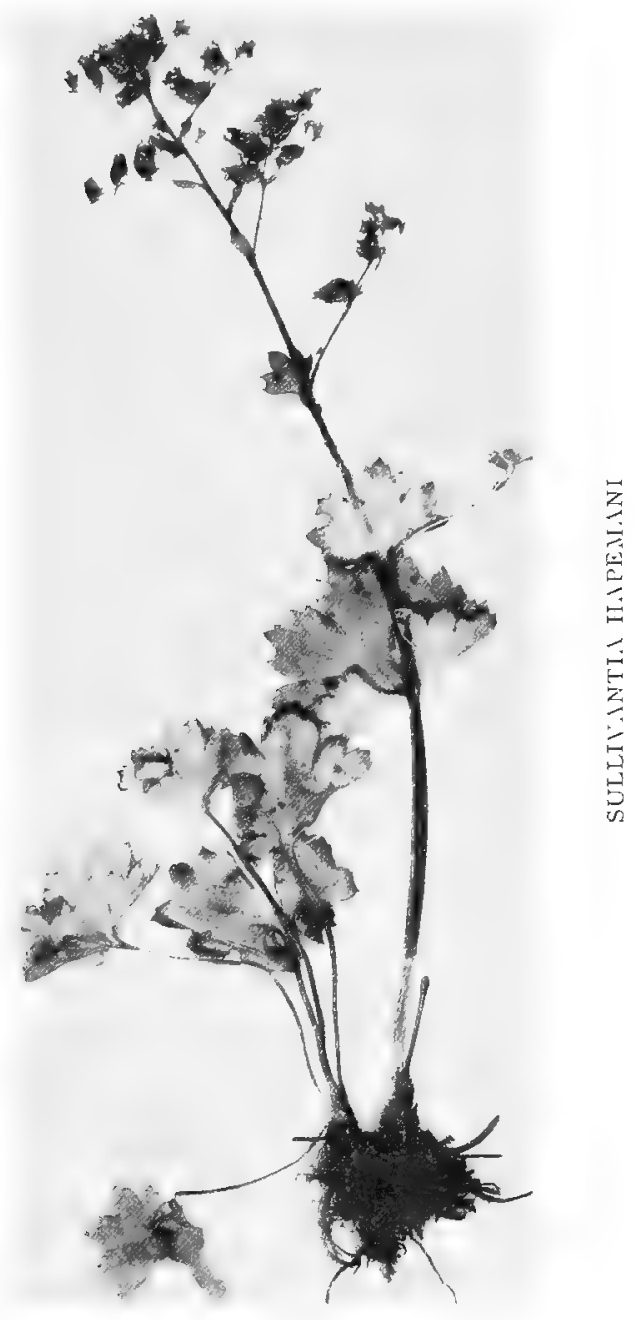



by Coulter. I have at present (I9I2) some new and undescribed species from the Hawaiian Islands which I have not yet had time to publish." 
A few other medical men who have been honored by floral tributes, concerning whom it was difficult to obtain more than a few scant biographical data, are:

William E. A. Aiken, I807-ı 888.

John Brickell, -1810, "aged about ninety" (Barnhart).

William P. Gibbons, I 8 I 2 - 1897.

Thomas Horsfield, I773-I859.

Albert Kellogg, I8I3-I887.

Melines Conklin Leavenworth, I796-г862.

William Tully, I785-I 859 .

William Zollickoffer, I793-1853. 






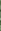
5.20

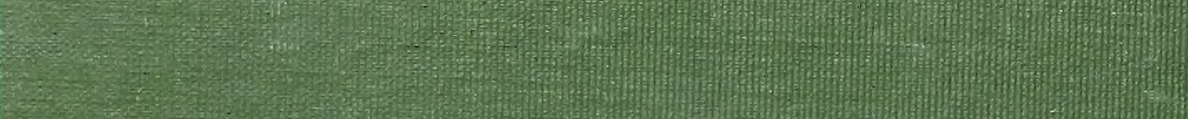

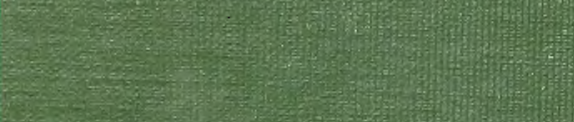

-

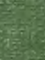

(6) (15)

$$
\text { : }
$$

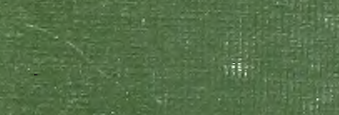
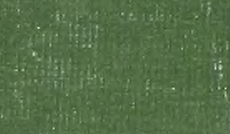

i.

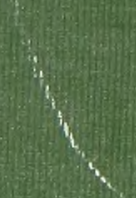

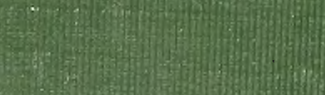

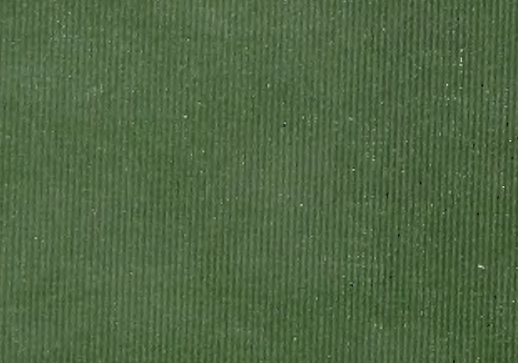

(3) a.

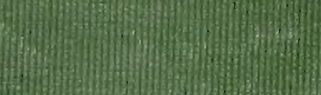

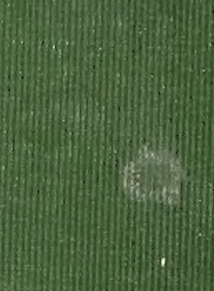

